SANDIA REPORT

SAND97-2789 • UC-601

Unlimited Release

Printed November 1997
RECEIVED

DEC 151997

OSTI

\title{
Stabilization and Solidification of Chromium-Contaminated Soil
}

\author{
C. A. Cherne, B. M. Thomson, R. Conway
}

Prepared by

Sandia National Laboratories

Albuquerque, New Mexico 87185 and Livermore, California 94550

Sandia is a multiprogram laboratory operated by Sandia Corporation, a Lockheed Martin Company, for the United States Department of Energy under Contract DE-AC04-94AL85000.

Approved for public release; further dissemination unlimited.
DATRABTION OF THS DOCUMENT IS UMAMIFEO

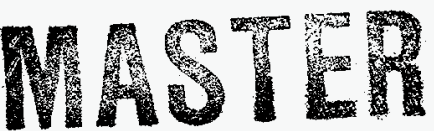

\section{Sandia National Laboratories}


Issued by Sandia National Laboratories, operated for the United States Department of Energy by Sandia Corporation.

NOTICE: This report was prepared as an account of work sponsored by an agency of the United States Government. Neither the United States Government nor any agency thereof, nor any of their employees, nor any of their contractors, subcontractors, or their employees, makes any warranty, express or implied, or assumes any legal liability or responsibility for the accuracy, completeness, or usefulness of any information, apparatus, product, or process disclosed, or represents that its use would not infringe privately owned rights. Reference herein to any specific commercial product, process, or service by trade name, trademark, manufacturer, or otherwise, does not necessarily constitute or imply its endorsement, recommendation, or favoring by the United States Government, any agency thereof, or any of their contractors or subcontractors. The views and opinions expressed herein do not necessarily state or reflect those of the United States Government, any agency thereof, or any of their contractors.

Printed in the United States of America. This report has been reproduced directly from the best available copy.

Available to $\mathrm{DOE}$ and $\mathrm{DOE}$ contractors from

Office of Scientific and Technical Information

P.O. Box 62

Oak Ridge, TN 37831

Prices available from (615) 576-8401, FTS 626-8401

Available to the public from

National Technical Information Service

U.S. Department of Commerce

5285 Port Royal Rd

Springfield, VA 22161

NTIS price codes

Printed copy: A06

Microfiche copy: A01 


\section{DISCLAMIER}

Portions of this doemenent mey be illegible in electronic image products. Images are produced from the best available original docoment 
SAND97-2789

Distribution

Unlimited Release

Category UC-601

Printed November 1997

\title{
Stabilization and Solidification of Chromium-Contaminated Soil
}

\author{
C. A. Cherne \\ Civil Engineering Department \\ B. M. Thomson \\ Professor of Civil Engineering \\ University of New Mexico \\ Albuquerque, NM 87131 \\ R. Conway \\ Environmental Restoration for Technical Areas \\ and Miscellaneous Sites Department \\ Sandia National Laboratories \\ P.O. Box 5800 \\ Albuquerque, NM 87185-1148
}

\begin{abstract}
Chromium-contaminated soil is a common environmental problem in the United States as a result of numerous industrial processes involving chromium. Hexavalent chromium [Cr(VI)] is the species of most concern because of its toxicity and mobility in groundwater. One method of diminishing the environmental impact of chromium is to reduce it to a trivalent oxidation state $[\mathrm{Cr}(\mathrm{III})]$, in which it is relatively insoluble and nontoxic. This study investigated a stabilization and solidification process to minimize the chromium concentration in the Toxicity Characteristic Leaching Procedure (TCLP) extract and to produce a solidified waste form
\end{abstract}


with a compressive strength in the range of 150 to 300 pounds per square inch (psi). To minimize the chromium in the TCLP extract, the chromium had to be reduced to the trivalent oxidation state. The average used in this study was an alluvium contaminated with chromic and sulfuric acid solutions. The chromium concentration in the in situ soil was 1212 milligrams per kilogram (mg/kg) total chromium and $275 \mathrm{mg} / \mathrm{kg} \mathrm{Cr}(\mathrm{VI})$. The effectiveness of iron, ferrous sulfide, blast furnace slag, ferrous ammonium sulfate, and ferrous sulfate to reduce $\mathrm{Cr}(\mathrm{VI})$ was tested in batch experiments. Ferrous sulfate was the reducing agent employed in this study due to acceptable kinetics and commercial availability. Cementto-soil ratios of 10 percent weight per weight $(\mathrm{w} / \mathrm{w})$ produced monoliths with compressive strengths greater than 1200 psi. Compressive strengths were reduced to target values using a cement-to-soil ratio of 6 percent $(\mathrm{w} / \mathrm{w})$. Initially, ferrous sulfate was added in proportion to the $\mathrm{Cr}(\mathrm{VI})$ concentration. This produced a soil concrete with TCLP extract concentrations near 2.5 milligrams per liter $(\mathrm{mg} / \mathrm{l})$ chrornium. The TCLP extract concentrations were reduced to $0.1 \mathrm{mg} / \mathrm{l}$ of $\mathrm{Cr}$ by increasing the amount of ferrous sulfate in proportion to the total chromium [Cr(VI) and CR(III)] concentration in the soil. The chromium concentration in the TCLP extract was reduced from $8.1 \mathrm{mg} / \mathrm{l}$ in the untreated soil to $0.1 \mathrm{mg} / 1$ by treatment ( 98.8 percent reduction). The quantity of reducing and solidifying agents used in preparing the soil concrete was optimized by considering the results obtained from the TCLP and unconfined compression testing.

\section{Acknowledgments}

I would like to thank the people at Intera, Inc. for their time and energy in providing the contaminated soil for this study. Thank you Cindy Ardito for the drill rig funding, Jim Studer for the planning effort, and Tony Martorana for the additional ES\&H concerns and suiting up in Level C PPE in August. 


\section{Contents}

Acronyms and Abbreviations

1. Introduction

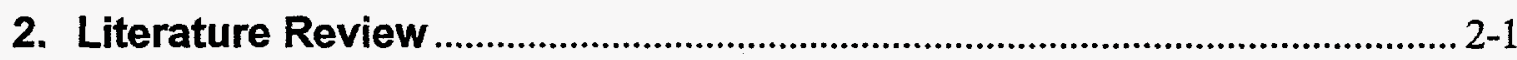

2.1 Stabilization and Solidification Background .................................................2-1

2.1.1 Portland Cement............................................................................ 2-1

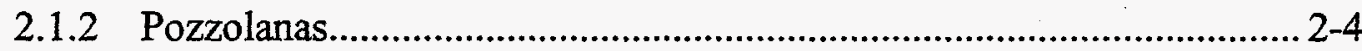

2.1.3 Limitation to the Solidification Process............................................... 2-4

2.2 Stabilization and Solidification Testing .......................................................... 2-5

2.3 Stabilization Theory ................................................................................... 2-6

2.4 Solidification Theory …………….................................................................... 2-7

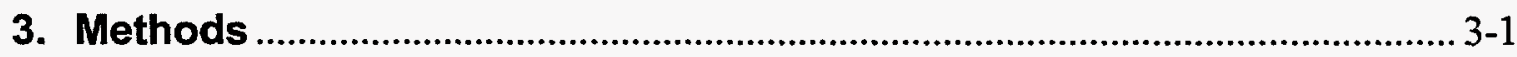

3.1 Soil Retrieval and Testing for Transportation ................................................. 3-1

3.2 Soil Physical Tests ...................................................................................... 3-1

3.2.1 Soil Moisture.............................................................................. 3-1

3.2.2 Sieve Analysis............................................................................ 3-1

3.2.3 Soil Absorption ........................................................................... 3-1

3.2.4 Loose Bulk Density.............................................................................. 3-2

3.3 Total Chromium Analysis..............................................................................

3.4 Colorimetric Analysis for Chromium (VI) ………..................................... 3-2

3.5 Reduction Experiments............................................................................. 3-2

3.6 Soil Chemical Tests .............................................................................. 3-3

3.6.1 Chromium Concentration and Speciation with Depth ........................... 3-3

3.6.2 Soil Compositing and Partitioning....................................................... 3-4

3.6.3 Chromium Concentration and Speciation in the Three Soil Classifications ................................................................................. 3-4

3.6.4 Sulfate Concentration..................................................................... 3-4

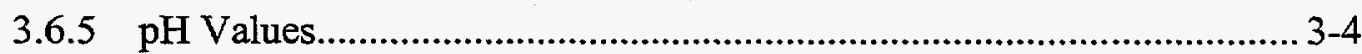

3.6.6 Soil Toxicity Characteristic Leaching Procedure ................................. 3-4

3.6.7 Sample Verification ...................................................................... $3-5$

3.7 Mortar Mixer Experiments ..................................................................... 3-6

3.8 Soil Concrete Methods and Tests .............................................................. 3-7

3.8.1 Soil Concrete Preparation ................................................................. 3-7

3.8.2 Soil Concrete Strength Testing …..................................................... 3-7

3.8.3 Soil Concrete Testing Using the Toxicity Characteristic

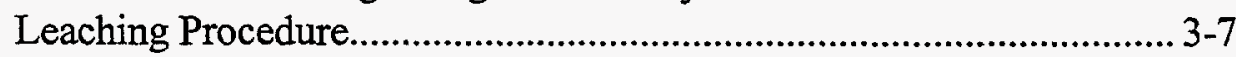

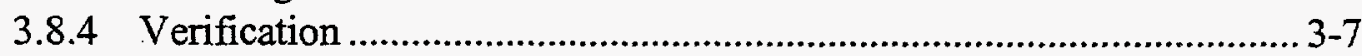




\section{Contents (Continued)}

3.9 Preliminary Soil Concrete Batches

3.10 Parameter Optimization

3.10.1 Second Optimization Step: Batches 1 through 11

3.10.2 Third Optimization Step: Batches 12 through 17

3.10.3 Confirmation Step: Batches 18, 19, and 20

3.11 Bulk Density

4. Results

4.1 Soil Physical Data

4.1.1 Soil Moisture

4.1.2 Sieve Analysis

4.1.3 Soil Absorption

4.1.4 Loose Bulk Density

4.2 Reduction Experiments

4.3 Soil Chemical Data

4.3.1 Chromium Concentration and Speciation with Depth

4.3.2 Chromium Concentration and Speciation in the Three Soil Classifications

4.3.3 Toxicity Characteristic Leaching Procedure

4.3.4 Sulfate Concentration.

4.3.5 pH Values.

4.4 Mortar Mixer Experiments

4.5 Uncontaminated Soil Concrete Data.

4.6 Second Optimization Step: Batches 1 through 11

4.7 Third Optimization Step: Batches 12 through 17

4.8 Confirmation Step: Batches 18, 19, and 20

4.9 Results of the Toxicity Characteristic Leaching Procedure for the Soil Concrete

4.10 Chromium Oxidation State in the Extract from the Toxicity

Characteristic Leaching Procedure

4.11 Soil Concrete Bulk Density

4.12 Soil Concrete Sulfate Concentration

4.13 Reduced Data. 
Contents (Concluded)

5. Discussion

5.1 Reduction Experiments

5.2 Toxicity Characteristic Leaching Procedure Extract:

Relationship of the Chromium Concentration to Ferrous Sulfate $5-1$

5.3 Toxicity Characteristic Leaching Procedure Extract 5-4

5.4 Stability of Trivalent Chromium in the Environment $5-5$

5.5 Particle Size Analysis: Effect on Soil Chromium Concentration. $5-5$

5.6 Importance of Studying the Waste $5-6$

5.7 Water-to-Cement Ratio 5-7

5.8 Effect of High Sulfate Concentration.............................................................. 5-7

5.9 Effect of Sodium Silicate Addition................................................................ 5-7

5.10 Verifying the Results of the Toxicity Characteristic Leaching Procedure

5.11 Additional Batch Experiment Information $5-8$

5.12 Field-Scale Operations $5-8$

6. Conclusions 6-1

7. References 


\section{Figures}

Figure

Page

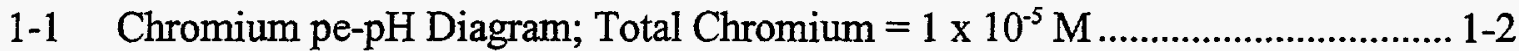

1-2 Chromium (III) Solubility Diagram ................................................................. 1-3

1-3 Total Chromium Concentration with Depth Determined by X-ray Fluorescence (XRF) Analysis............................................................................ 1-5

2-1 Relationship Between the Compressive Strength and the

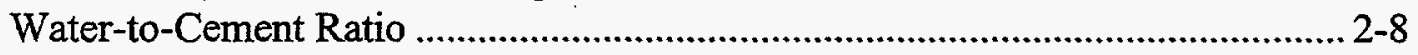

2-2 Compressive Strength as a Function of Cement Content and Time for a Sandy Gravel.

3-1 Scatter Plot Showing the Relationship Between Undigested and Digested Toxicity Characteristic Leaching Procedure Extract Concentrations..................... 3-5

3-2 Soil Concrete Monolith Before Splitting................................................................. 3-8

3-3 Soil Concrete Monolith After Splitting .................................................................. 3-8

3-4 Crushed Soil Concrete Ready for the Toxicity Characteristic Leaching Procedure. 3-9

3-5 Optimization Process Flowchart ................................................................. 3-11

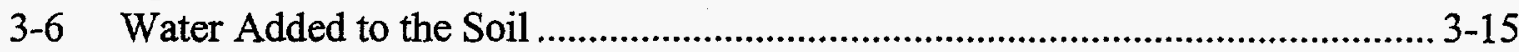

3-7 Addition of Ferrous Sulfate to Batch 18 ........................................................ 3-15

3-8 Prepared Soil Concrete Ready to be Placed into Molds......................................... 3-16

3-9 Addition of Cement and Sodium Silicate to Batch 19 ........................................ 3-16

4-1 Floc Produced in Reduction Experiments 12 and 13 .......................................... 4-8

4-2 Floc Produced in Reduction Experiment 13..................................................... 4-8

4-3 Reduction Experiment 10 Samples Prepared for Colorimetric Analysis .............. 4-9

4-4 Reduction Experiments 12 and 13 Prepared for Colorimetric Analysis ............. 4-10

4-5 Chromium Oxidation State with Depth Below the Disposal Pit........................... 4-11

4-6 Chromium Oxidation State in the Three Soil Classifications ............................. 4-12

4-7 Compressive Strength of Uncontaminated Soil Concrete ................................... 4-14

4-8 Compressive Strength of Batches 1 through 7 .................................................... 4-15

4-9 Compressive Strength of Batches 8 through 11 ................................................ 4-15

4-10 Compressive Strength of Batch Couples.............................................................. 4-16

4-11 Experiment Results for Extract Concentrations Using the Toxicity Characteristic Leaching Procedure, Batches 1 through 7 .................................... 4-16

4-12 Experiment Results for Extract Concentrations Using the Toxicity Characteristic Leaching Procedure, Batches 8 through 11................................ 4-17

4-13 Experiment Results for Extract Concentrations Using the Toxicity Characteristic Leaching Procedure, Batch Couples ............................................ 4-17

4-14 Compressive Strength of Batches 12 through 17 ................................................. 4-18

4-15 Experiment Results for Extract Concentrations Using the Toxicity Characteristic Leaching Procedure, Batches 12 through 17 ................................ 4-19 


\section{Figures (Concluded)}

Figure

Page

4-16 Experiment Results for Extract Concentrations Using the Toxicity

Characteristic Leaching Procedure, Batches 12 through 17.

4-17 Experiment Results for Extract Concentrations Using the Toxicity

Characteristic Leaching Procedure, Batches 13 through 16.

4-18 Compressive Strength of Batches 18, 19, and 20

4-19 Experiment Results for Extract Concentrations Using the Toxicity Characteristic Leaching Procedure, Batch 18.

4-20 Experiment Results for Extract Concentrations Using the Toxicity Characteristic Leaching Procedure, Batches 19 and 20 4-22

4-21 Photograph of Soil Concrete Using Uncontaminated Soil 4-25

4-22 Photographs of Batches 1 through 5 Soil Concrete. 4-26

4-23 Photograph of Batches 12, 13, and 14 Soil Concrete 4-27

4-24 Photograph of Batches 15, 16, and 17 Soil Concrete 4-27

4-25 Photograph of Soil Concrete Samples Split in Half 4-28

4-26 Photograph of Batches 18 and 19 Soil Concrete Cured for 3 Days 4-28

4-27 Photograph of Batch 18 Soil Concrete 4-29

5-1 Schematic of Effects of Stabilization/Solidification Process on Chromium Speciation; Total $[\mathrm{Cr}]=1 \times 10^{-5} \mathrm{M}$

5-2 Photograph of the Soil . 5-6

5-3 Diagram of pe-pH for Nitrogen; Total $[\mathrm{N}]=1 \times 10^{-3} \mathrm{M}$ $5-10$ 


\section{Tables}

Table

2-1 Results of Soil Analysis Performed at Sandia National Laboratories/ New Mexico Field Laboratories. $2-2$

2-2 Primary Constituents of Portland Cement

2-3 Example Specifications for Solidified Waste for Land Burial

3-1 Composition of Batches 1 through 11 …….............................................................. 3-13

3-2 Composition of Batches 12 through 17 …............................................................. 3-14

3-3 Composition of Batches 18, 19, and 20.

4-1 Soil Moisture Results 4-1

4-2 Sieve Analysis Results

4-3 Soil Absorption Results

4-4 Reduction Experiments Using Fe(0), Blast Furnace Slag, or Steel Wool.. 4-4

4-5 Reduction Experiments Using Ferrous Sulfide

4-6 Reduction Experiments Using Ferrous Sulfate or Ferrous Ammonium Sulfate

4-7 Reduction Experiments Using Ferrous Sulfate and Uncontaminated Soil

4-8 Results of the Toxicity Characteristic Leaching Procedure for the Three Soil Classifications

4-9 Sulfate Concentration

4-10 Results of the Toxicity Characteristic Leaching Procedure for the Soil Concrete.

4-11 Bulk Density of Selected Soil Concrete Samples

5-1 Average pH Values of Toxicity Characteristic Leaching Procedure Extracts 5-4 


\section{Acronyms and Abbreviations}

AASHTO

AA

ASTM

bgs

BFS

Cr

Cr(III)

Cr(VI)

CWL

DI

EPA

FAS

$\mathrm{Fe}$

FeS

FLAA

FS

GEL

ICP

RCRA

SNL/NM

TCLP

UCAP

UNM

VOC

XRF
American Association of State Highway and Transportation Offices atomic absorption

American Society for Testing and Materials

below ground surface

blast furnace slag

chromium

trivalent chromium

hexavalent chromium

Chemical Waste Landfill

deionized (water)

U.S. Environmental Protection Agency

ferrous ammonium sulfate

iron

ferrous sulfide

flame atomic absorption spectroscopy

ferrous sulfate

General Engineering Laboratories

Inductively Coupled Plasma

Resource Conservation and Recovery Act

Sandia National Laboratories/New Mexico

Toxicity Characteristic Leaching Procedure

unlined chromic acid pit

University of New Mexico

volatile organic compound

$\mathrm{X}$-ray fluorescence 


\section{Acronyms and Abbreviations (Concluded)}

\section{Units of Measure}

$\begin{array}{ll}\mathrm{cm} / \mathrm{sec} & \text { centimeters per second } \\ \mathrm{ft} & \text { feet } \\ \mathrm{ft}^{3} & \text { cubic feet } \\ \mathrm{g} & \text { gram(s) } \\ \mathrm{gal} . & \text { gallon(s) } \\ \mathrm{hr} & \text { hour(s) } \\ \mathrm{in} . & \text { inch(es) } \\ \mathrm{kg} & \text { kilogram(s) } \\ \mathrm{l} & \text { liter(s) } \\ \mathrm{lb} & \text { pound(s) } \\ \mathrm{M} & \text { moles/liter } \\ \mathrm{mg} / \mathrm{kg} & \text { milligram(s) per kilogram (ppm) } \\ \mu \mathrm{g} / \mathrm{kg} & \text { microgram(s) per kilogram (ppb) } \\ \mu \mathrm{g} / 1 & \text { microgram(s) per liter } \\ \mathrm{ml} & \text { milliliter(s) } \\ \mathrm{mm} & \text { millimeters } \\ \mu \mathrm{m} & \text { micrometer(s) } \\ \mathrm{N} / \mathrm{sq} \mathrm{mm} & \text { Newton/square millimeter } \\ \mathrm{pCi} / \mathrm{g} & \text { picocuries per gram } \\ \mathrm{ppb} & \text { parts per billion } \\ \mathrm{ppm} & \text { parts per million } \\ \mathrm{qt} & \text { quart(s) } \\ \mathrm{sec} & \text { second(s) } \\ \mathrm{w} / \mathrm{w} & \text { weight per weight } \\ \mathrm{yd} & \text { yard(s) } \\ \mathrm{yd} & \text { cubic yard(s) } \\ \mathrm{yr} & \text { year(s) } \\ & \end{array}$




\section{Stabilization and Solidification of Chromium-Contaminated Soil}

\section{Introduction}

Sandia National Laboratories in Albuquerque, New Mexico (SNL/NM) may have as much as 10,000 cubic yards $\left(\mathrm{yd}^{3}\right)$ of chromium-contaminated soil in the Chemical Waste Landfill (CWL). The chromium was dumped in unlined pits during the $1960 \mathrm{~s}$ and $1970 \mathrm{~s}$ as waste from metal-plating and glassware-cleaning operations. The waste from metalplating operations disposed chromium as $\mathrm{Cr}(\mathrm{III})$ and waste from glassware-cleaning operations disposed chromium as $\mathrm{Cr}(\mathrm{VI})$.

Chromium has nine oxidation states ranging from -2 to +6 ; however, in the environment, chromium primarily exists in the +3 and +6 oxidation states. For this reason, this study has focused on the trivalent $(+3)$ and hexavalent $(+6)$ oxidation states.

Chromium, regulated by the U.S. Environmental Protection Agency (EPA) as a suspected mutagen and carcinogen for humans, is also toxic to animals, especially fish. The ambient water quality standard for total chromium is 50 micrograms per liter $(\mu \mathrm{g} / 1)$, and the criterion for $\mathrm{Cr}$ (VI) to protect aquatic life is $0.29 \mu \mathrm{g} / 1$ (EPA 1980a). $\mathrm{Cr}$ (III) is less toxic than $\mathrm{Cr}(\mathrm{VI})$; however, $\mathrm{Cr}(\mathrm{III})$ can be oxidized to $\mathrm{Cr}(\mathrm{VI})$ by hypochlorite and chlorine, which may be present in drinking and waste water (Kroschwitz 1993).

The mutagenic and carcinogenic qualities of $\mathrm{Cr}$ (VI) have been identified by animal and epidemiological studies; most of these studies have focused on $\mathrm{Cr}(\mathrm{VI})$. The key to Cr(VI)'s mutagenicity and possible carcinogenicity is the ability of this oxidation state to penetrate the cell membrane (Kroschwitz 1993).

$\mathrm{Cr}(\mathrm{VI})$ is soluble and therefore mobile in groundwater, whereas $\mathrm{Cr}(\mathrm{III})$ is highly immobile. $\mathrm{Cr}(\mathrm{VI})$ exists in aqueous solution as the anions chromate $\left(\mathrm{CrO}_{4}{ }^{2-}\right)$ and dichromate $\left(\mathrm{Cr}_{2} \mathrm{O}_{7}{ }^{2-}\right)$. Figure 1-1 shows chromium speciation affected by pe and $\mathrm{pH}$. As anions, chromate and dichromate do not complex with hydroxides or oxides and remain in solution. Conversely, $\mathrm{Cr}$ (III) will complex with oxides and hydroxides and precipitate above $\mathrm{pH}$ 4.5. Most groundwater $\mathrm{pH}$ is above 5; therefore, $\mathrm{Cr}(\mathrm{III})$ will precipitate out of solution. Figure 1-2 shows the low solubility of $\mathrm{Cr}$ (III).

Wastes from chromium manufacturing processes must be handled in strict accordance with the Resource Conservation and Recovery Act (RCRA). Other wastes, such as soil contaminated with chromium, can be determined to be hazardous by the Toxicity Characteristic Leaching Procedure (TCLP), an EPA procedure that leaches the contaminant out of the soil. A waste is considered hazardous and must be controlled by RCRA if the TCLP leachate concentration contains 5 milligrams per liter (mg/l) or more of total chromium (EPA 1996). 


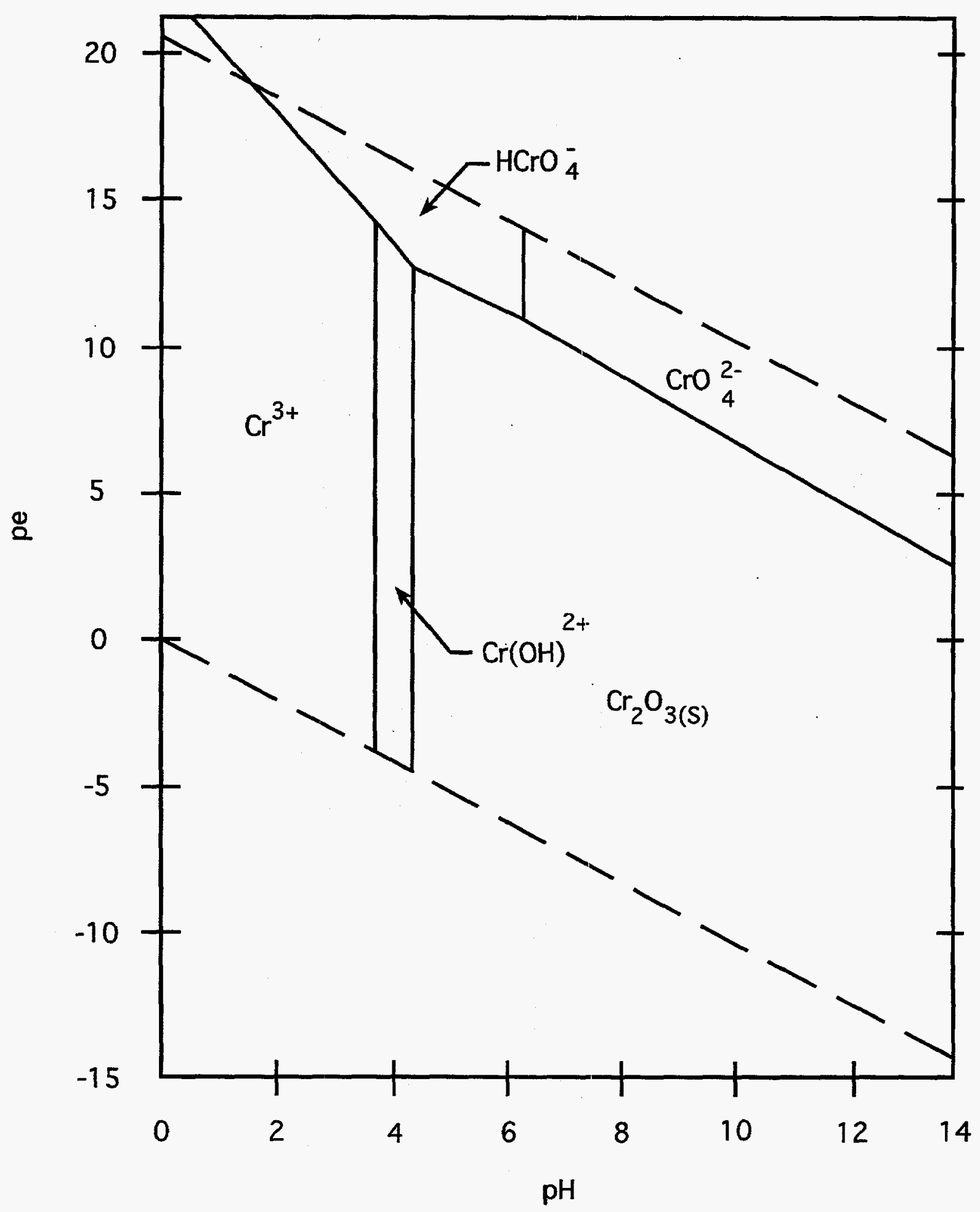

Figure 1-1. Chromium pe-pH Diagram; Total Chromium $=1 \times 10^{-5} \mathrm{M}$ (after Thomson 1987) 


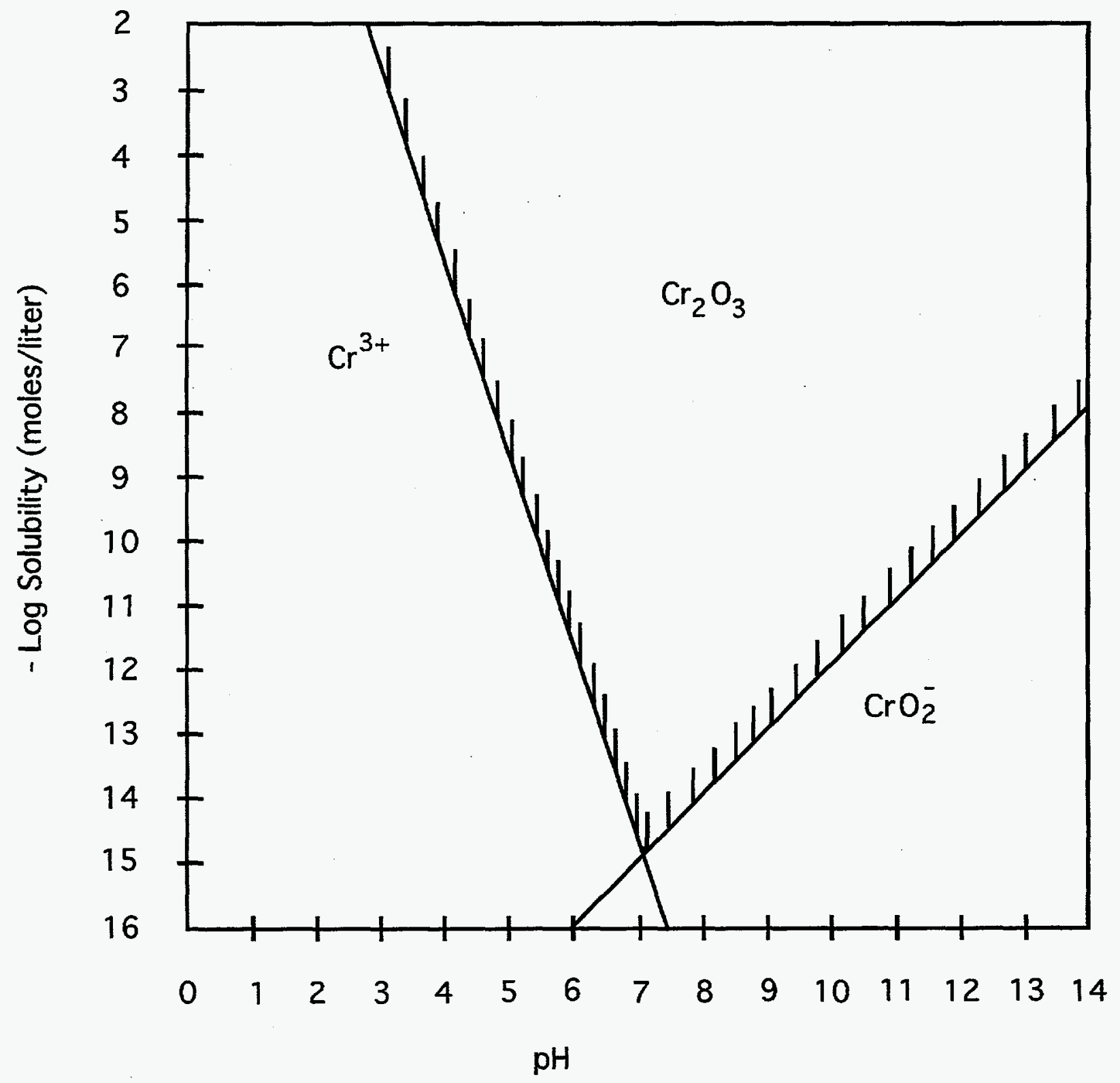

Figure 1-2. Chromium (III) Solubility Diagram 
Soil samples used in this study were obtained from the unlined chromic acid pit (UCAP) in the CWL at SNL/NM. The UCAP received chromic acid wastes from the early 1970s to 1978 (SNL/NM 1993). The highest chromium concentration (4500 milligrams $[\mathrm{mg}]$ of chromium per kilogram $[\mathrm{kg}]$ of soil) has been identified at a depth of 10 to 13 feet ( $\mathrm{ft}$ ) below ground surface (bgs), which corresponds to the bottom of the pit. As can be seen in Figure 1-3, the chromium concentration in the soil tapers off with depth.

Management of the CWL is regulated through State of New Mexico Hazardous Waste Regulations. The site is considered an Interim Status Facility undergoing corrective action prior to regulatory closure in 1998. Corrective action may.include treatment, control, or remediation of the UCAP and other chromium-contaminated portions of the CWL (SNL/NM 1992).

One potential technology that may be applied to remediate the chromiumcontaminated soil is stabilization and solidification. Stabilization techniques reduce the toxicity of a contaminant by changing the chemical form and reducing the solubility of the contaminant so that it is less mobile. The object of solidification techniques is to produce a solid block or "monolith" with high structural integrity and lower permeability.

Another potential treatment-soil washing to separate the contaminant from the soil-can reduce the volume of contaminated soil by removing the contamination from gravel and larger soil particles. The remaining contaminated soil can be stabilized and solidified to render it nonhazardous per RCRA.

The objectives of this study were to stabilize and solidify the chromiumcontaminated soil to minimize the chromium concentration in the TCLP extract and to produce a monolith with a compressive strength in the range of 150 to 300 pounds per square inch (psi). This range of compressive strength was chosen to minimize the quantity of cement used while at the same time providing structural integrity so that land disposal in an engineered disposal cell would be possible. One goal was to reduce the chromium concentration in the TCLP extract to below the regulatory level so that the treated waste would be nonhazardous. Other goals of this study were to formulate a process that is applicable to field operations, to optimize the quantity of stabilization and solidification agents required to reduce the cost of the process, and to determine whether sodium silicate reduced the amount of chromium in the TCLP leachate. To accomplish these goals, suitable reducing and solidification agents needed to be identified. 


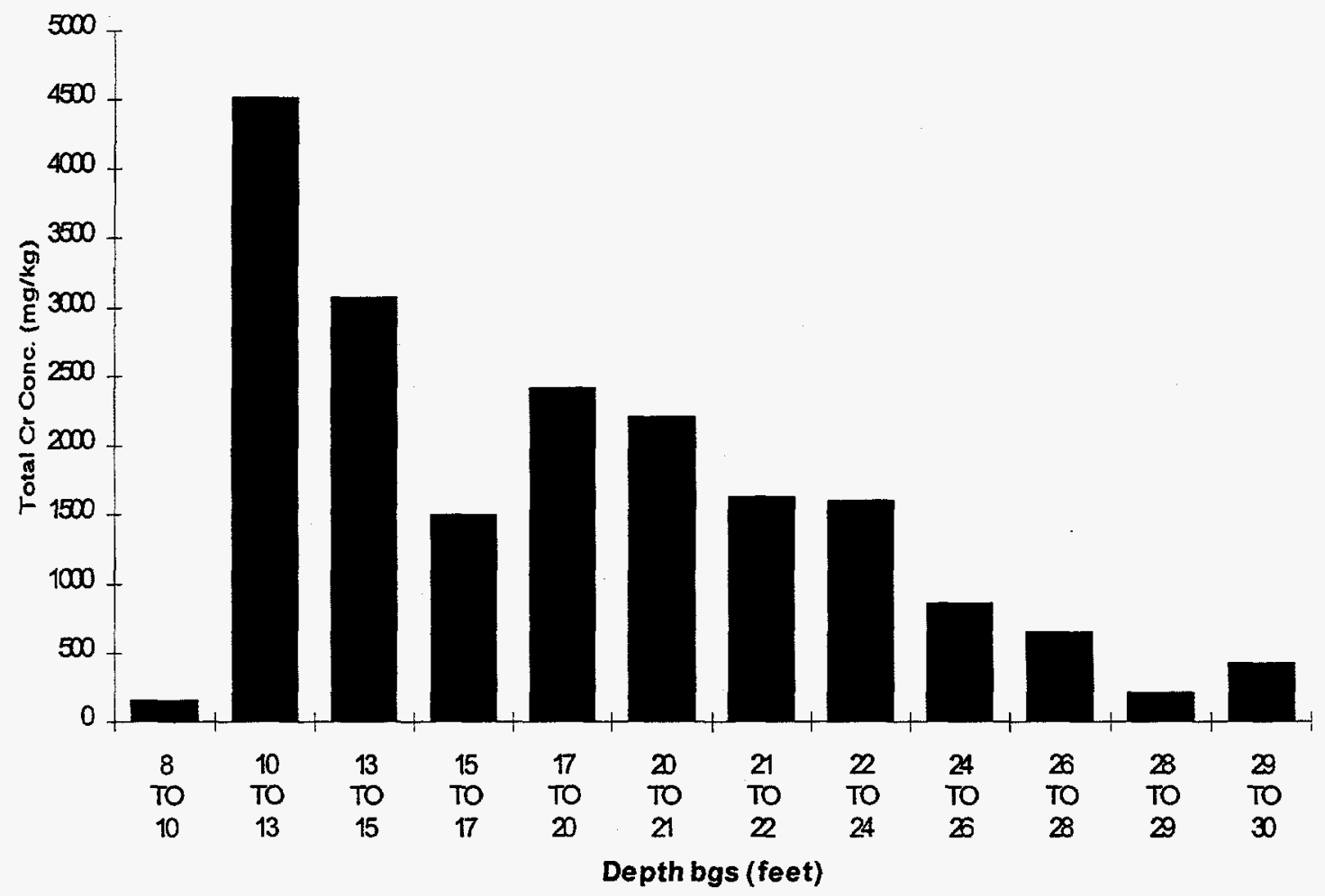

Figure 1-3. Total Chromium Concentration with Depth Determined by X-ray Fluorescence (XRF) Analysis 


\section{Literature Review}

Review was performed to investigate the presently available technology. This section also summarizes the stabilization and solidification theory.

\subsection{Stabilization and Solidification Background}

The first step in this study was to determine whether stabilization and solidification processes are applicable to the waste form. The soil to be treated has been contaminated primarily with metals. As shown in Table 2-1, the soil contains metals and organics, as well as, copper, barium, vanadium and lead. As stated by Jackman and Powell (1991), "Cement solidification is most suitable for treating inorganic wastes, especially those containing metals." The EPA states that wastes most effectively stabilized and solidified consist of inorganic materials in aqueous solution or suspension which contain appreciable amounts of toxic heavy metals and inorganic salts (EPA 1980b). The soil treated in this study is an inorganic waste contaminated with chromium. Based upon cited references and waste characterization data, stabilization and solidification appear to be an appropriate technology for treating this waste form.

To stabilize chromium, it must be reduced to, and remain, as $\mathrm{Cr}(\mathrm{III})$. Chromium is widely known as an oxidizing agent and therefore can be reduced by numerous agents. The appropriate reducing agent depends on the $\mathrm{pH}$, the other species that may aid or interfere with the reaction, the reaction rate, and the cost. Scrap iron, ferrous sulfate, sodium bisulfite, sulfur dioxide, sodium hydrosulfite, and sulfide wastes have all been employed as reducing agents for waste streams containing $\mathrm{Cr}(\mathrm{VI})$ (Kroschwitz 1993). Chemicals such as sodium metabisulfite, ferrous sulfate, and ferrous ammonium sulfate can be utilized to reduce $\mathrm{Cr}$ (VI) (Jacobs 1992). It is possible to convert $\mathrm{Cr}$ (VI) to $\mathrm{Cr}$ (III) with a chemical reducing agent such as sulfur dioxide, sodium bisulfite, metabisulfite or hydrosulfite, or ferrous sulfate (Patterson 1985). Zero-valent iron has been used for in situ $\mathrm{Cr}(\mathrm{VI})$ reduction (Blowes et al. 1995).

After the $\mathrm{Cr}(\mathrm{VI})$ is stabilized, the relatively inert mass should be solidified. The discussion on solidification will be limited to Portland cement-based and pozzolanic processes. Other processes exist, including encapsulation and vitrification, that are employed mostly in the radiological waste arena. These processes could not be performed in the laboratory, and it was evident that cement and pozzolanic processes would be effective.

\subsubsection{Portland Cement}

Portland cement processes are commonly used for solidification of hazardous wastes for several reasons: the cement composition is more consistent from source to source (Conner 1990); much more is known about the Portland cement reactions in setting and hardening, and more recently, in the fixation of metals (Conner 1990); and the cement is readily available. The American Society for Testing and Materials (ASTM) provides control guidelines (ASTM C150-94) (ASTM 1995a) to ensure that the composition of cement is consistent from source to source. 
Table 2-1. Results of Soil Analysis Performed at Sandia National Laboratories/New Mexico Field Laboratories

\begin{tabular}{|c|c|c|c|c|c|c|c|c|c|c|c|c|c|c|}
\hline $\begin{array}{c}\text { Sample } \\
\text { Depth } \\
\text { (ft bgs) }\end{array}$ & K (\%) & $\mathrm{Ca}(\%)$ & Ti (ppm) & $V(p p m)$ & $\operatorname{Cr}(\mathrm{ppm})$ & Mn (ppm) & $\mathrm{Fe}(\%)$ & Cu (ppm) & $\mathrm{Zn}(\mathrm{ppm})$ & Ba (ppm) & $\mathrm{Pb}$ (ppm) & $\begin{array}{l}\text { Pyridine } \\
\text { (ppm) }\end{array}$ & TCE (ppb) & TCA (ppb) \\
\hline 8 to 10 & 1.9 & 5.0 & 1806 & 51.00 & 157 & 144 & 1.4 & 27 & 6 & 285 & 15 & 0 & 0 & 0 \\
\hline 10 to 13 & 1.9 & 5.8 & 1801 & 60.00 & 4518 & 153 & 1.4 & 1366 & 4 & 301 & 21 & 100 & 4.5 & 6.1 \\
\hline 13 to 15 & 2.1 & 6.1 & 1374 & 27.00 & 3079 & 201 & 1.2 & 1551 & 15 & 320 & 20 & 100 & 1.8 & 3.2 \\
\hline 15 to 17 & 2.2 & 5.4 & 1458 & 45.00 & 1504 & 139 & 1.1 & 586 & 0 & 301 & 20 & 30 & 1.6 & 0 \\
\hline 17 to 20 & 1.8 & 4.0 & 1076 & 11.00 & 2422 & 95 & 0.8 & 833 & 0 & 175 & 11 & 0 & 0 & 0 \\
\hline 20 to 21 & 2.0 & 7.2 & 1243 & 46.00 & 2214 & 190 & 1.1 & 1066 & 0 & 331 & 12 & 20 & 1.3 & 0 \\
\hline 21 to 22 & 2.0 & 6.1 & 1447 & 8.00 & 1636 & 193 & 1.1 & 773 & 0 & 264 & 16 & 20 & 0 & 0 \\
\hline 22 to 24 & 2.0 & 4.3 & 1480 & 0.20 & 1608 & 113 & 1.1 & 657 & 0 & 302 & 0.9 & 30 & 2 & 0 \\
\hline 24 to 26 & 2.1 & 5.3 & 1260 & 22.00 & 866 & 169 & 1.1 & 406 & 0 & 198 & 14 & 15 & 0 & 0 \\
\hline 26 to 28 & 2.3 & 6.6 & 1383 & 26.00 & 658 & 159 & 1.2 & 243 & 0 & 340 & 19 & 0 & 0 & 0 \\
\hline 28 to 29 & 2.0 & 6.2 & 1266 & 6.40 & 218 & 148 & 1 & 52 & 0 & 250 & 20 & 0 & 0 & 0 \\
\hline 29 to 30 & 2.3 & 4.1 & 1398 & 9.60 & 428 & 143 & 1 & 145 & 0 & 370 & 19 & 10 & 0 & 0 \\
\hline $\begin{array}{l}\text { verage } \\
\text { oncentration }\end{array}$ & 2.1 & 5.5 & 1416 & 26 & 1609 & 154 & 1.1 & 642 & 2.1 & 286 & 16 & 27 & 0.93 & 0.78 \\
\hline
\end{tabular}


The principal raw materials used in the manufacture of cement are

1. Argillaceous, or silicates of alumina, in the form of clays and shales, and

2. Calcareous, or calcium carbonate, in the form of limestone, chalk, and marl (which is a mixture of clay and calcium carbonate) (Orchard 1979).

Two parts calcareous material and one part argillaceous material are mixed and ground, then fired at $1400^{\circ} \mathrm{C}$ to $1500^{\circ} \mathrm{C}$. The resulting clinker is then ground with a small amount of gypsum to produce Portland cement (Orchard 1979). The primary constituents of Portland cement are tricalcium silicate $\left(\mathrm{C}_{3} \mathrm{~S}\right)$, dicalcium silicate $\left(\mathrm{C}_{2} \mathrm{~S}\right)$, tricalcium aluminate $\left(\mathrm{C}_{3} \mathrm{~A}\right)$, and calcium aluminoferrite $\left(\mathrm{C}_{4} \mathrm{AF}\right)$. Table 2-2 shows the amount of each of these constituents in Portland cement.

Table 2-2. Primary Constituents of Portland Cement

\begin{tabular}{|l|c|}
\hline \multicolumn{1}{|c|}{ Constituent } & Percent \\
\hline Tricalcium Silicate $\left(\mathrm{C}_{3} \mathrm{~S}\right)$ & 50 \\
\hline Dicalcium Silicate $\left(\mathrm{C}_{2} \mathrm{~S}\right)$ & 25 \\
\hline Tricalcium Aluminate $\left(\mathrm{C}_{3} \mathrm{~A}\right)$ & 10 \\
\hline Calcium Aluminoferrite $\left(\mathrm{C}_{4} \mathrm{AF}\right)$ & 10 \\
\hline Oxides & 5 \\
\hline
\end{tabular}

Source: Conner (1990). 
There are five types of Portland cement:

- Type I-General-purpose cement, typically used in the building trade.

- Type I-Designed to be used in the presence of moderate sulfate concentrations $(150$ to $1500 \mathrm{mg} / \mathrm{kg}$ ).

- Type III-High early-set cement, used in cold weather.

- Type IV-Low heat-of-hydration cement, used in massive structures where the temperature rise must be limited.

- Type V-Sulfate-resisting cement, used with high sulfate concentrations $(>1500 \mathrm{mg} / \mathrm{kg}$ ).

Types I, II, and V are most commonly used in solidification processes (EPA 1980b).

Portland cements are used in conjunction with soluble silicates to solidify wastes. Soluble silicates may reduce the leachability of toxic metal ions by forming lowsolubility metal oxide/silicates and by encapsulating metal ions in a matrix of silicate gel or metal silicate gel (Conner 1990). Soluble silicates also decrease the permeability of the monolith (Glasser 1992). Two common soluble silicates are sodium silicate $\left(\mathrm{Na}_{2} \mathrm{SiO}_{3}\right)$ and potassium silicate $\left(\mathrm{K}_{2} \mathrm{SiO}_{3}\right)$.

\subsubsection{Pozzolanas}

Pozzolanic processes employ lime and a natural or manmade pozzolana (fine grained, siliceous) to form compounds of low solubility having cementitious properties (Orchard 1979). Some natural pozzolanas are clays and shales that need to be calcined to become active, volcanic tuffs and pumites, and diatomaceous earth that may or may not need to be calcined (Orchard 1979). Manmade pozzolanas used in solidification are cement-kiln dust, ground blast furnace slag, and fly ash (EPA 1980b). Manmade pozzolanas are themselves waste products, and for this reason, they were introduced into the arena of hazardous and radioactive waste solidification. Manmade pozzolanic cements are commonly employed in waste solidification when the pozzolana can be acquired locally. When available locally, the material is inexpensive and a viable alternative to Portland cement.

\subsubsection{Limitation to the Solidification Process}

Certain compounds interfere with the setting, curing, and leachability of concrete. Zinc, cadmium, and chromium may cause expansion and cracking of the cement and thus can lead to increased leaching of physically bound waste constituents (Trussell and Spence 1994). All insoluble material small enough to pass a No. 200 sieve can coat the 
larger particles and weaken the bond between particles and the cement (EPA 1980b). Soluble salts of zinc, copper, and lead cause large variations in setting time and reduced strength (EPA 1980b). The presence of sulfates also degrades the concrete integrity by forming sulpho-aluminates which have expansive properties and cause disintegration (Orchard 1979).

\subsection{Stabilization and Solidification Testing}

Testing, an integral part of the stabilization/solidification process, is performed on the waste before treatment to determine any necessary handling and safety precautions and to define parameters to be used in the stabilization/solidification process. The EPA recommends the following tests be performed on the waste (EPA 1986):

1. Percent moisture

2. Suspended solids

3. Bulk density

4. Grain-size distribution

5. Atterberg limits

6. Cone index or California bearing ratio

Not all of these tests are applicable to any one waste stream. The investigator must decide which tests will be performed. A pH test also can provide useful information.

Tests also need to be performed on the treated waste to determine whether it is still hazardous, and to be able to compare results to similar work. Table 2-3 shows an example of the tests that can be performed on stabilized and solidified waste. This study will use leachability and strength testing to optimize the amount of reducing agent and cement used. 
Table 2-3. Example Specifications for Solidified Waste for Land Burial

\begin{tabular}{|l|l|}
\hline \multicolumn{1}{|c|}{ Characteristic } & \multicolumn{1}{c|}{ Recommended Value } \\
\hline Leachability & $\begin{array}{l}\text { Pass Toxicity Characteristic Leaching } \\
\text { Procedure (TCLP) }\end{array}$ \\
\hline Physical stability & $\begin{array}{l}\text { Will not allow unacceptable settlement } \\
\text { under landfill design conditions }\end{array}$ \\
\hline Reactivity & Nonreactive \\
\hline Ignitability & Nonpyrophoric \\
\hline Ability to support microbial growth & No microbial growth observed \\
\hline Strength & Greater than $150 \mathrm{psi}$ \\
\hline Permeability & Less than $10^{-5} \mathrm{~cm} / \mathrm{sec}$ \\
\hline Durability & As required per site design \\
\hline
\end{tabular}

Source: EPA (1986).

\subsection{Stabilization Theory}

To stabilize the contaminated soil, the $\mathrm{Cr}(\mathrm{VI})$ must be reduced to $\mathrm{Cr}(\mathrm{III})$. Four reducing agents were used in this study to reduce the $\mathrm{Cr}$ (VI): zero-valent iron, ferrous sulfide, ferrous sulfate, and ferrous ammonium sulfate. The reduction-oxidation reactions, presented below, are for a pH range of 4.5 to 9.0. The reactions assume ferric hydroxide and eskolaite $\left(\mathrm{Cr}_{2} \mathrm{O}_{3}\right)$ are reaction products. $\mathrm{Fe}(\mathrm{OH})_{3}$ and $\mathrm{Cr}_{2} \mathrm{O}_{3}$ were assumed to be the reaction products based on the following explanation: $\mathrm{Fe}(\mathrm{II})$ is oxidized to $\mathrm{Fe}$ (III) to provide electrons for the chromium reduction. $\mathrm{Fe}(\mathrm{OH})_{3}$ is the species most likely to form and precipitate due to the pe and $\mathrm{pH}$ range used in this work (Pankow 1991). $\mathrm{Cr}_{2} \mathrm{O}_{3}$ was assumed as the chromium species to form and precipitate due to a visual observation of a green precipitate upon acidification of a $\mathrm{Cr}$ (III) solution and work performed by Thomson (1987).

The reduction reaction is independent of the reducing agent employed-

$$
6 \mathrm{e}^{-}+10 \mathrm{H}^{+}+2 \mathrm{CrO}_{4}{ }^{2-}=\mathrm{Cr}_{2} \mathrm{O}_{3}+5 \mathrm{H}_{2} \mathrm{O}
$$

Based on literature review, zero-valent iron was used initially to reduce $\mathrm{Cr}$ (VI).

The reduction-oxidation reaction employing $\mathrm{Fe}^{0}$ as the reducing agent is:

$$
2 \mathrm{Fe}^{0}+2 \mathrm{CrO}_{4}{ }^{2-}+4 \mathrm{H}^{+}+\mathrm{H}_{2} \mathrm{O}=2 \mathrm{Fe}(\mathrm{OH})_{3}+\mathrm{Cr}_{2} \mathrm{O}_{3}
$$


Ferrous sulfide also has the potential to reduce $\mathrm{Cr}(\mathrm{VI})$, with ferrous iron $\left(\mathrm{Fe}^{2+}\right)$ oxidized to $\mathrm{Fe}^{3+}$ :

At $\mathrm{pH}$ of 7.0 or greater, $\mathrm{H}_{2} \mathrm{~S}$ will dissociate into $\mathrm{H}^{+}$and $\mathrm{HS}^{-}$.

The overall reaction utilizing FeS as the reducing agent is:

$$
6 \mathrm{FeS}+2 \mathrm{CrO}_{4}^{2-}+4 \mathrm{H}^{+}+13 \mathrm{H}_{2} \mathrm{O}=6 \mathrm{Fe}(\mathrm{OH})_{3}+\mathrm{Cr}_{2} \mathrm{O}_{3}+6 \mathrm{H}_{2} \mathrm{~S}
$$

Kroschwitz (1903), Jacobs (1992), and Patterson (1985) mentioned the use of ferrous sulfate to reduce $\mathrm{Cr}(\mathrm{VI})$.

The reduction-oxidation reaction using $\mathrm{FeSO}_{4} \cdot 7 \mathrm{H}_{2} \mathrm{O}$ as the reducing agent is:

$$
2 \mathrm{CrO}_{4}{ }^{2-}+6 \mathrm{FeSO}_{4} \cdot 7 \mathrm{H}_{2} \mathrm{O}=6 \mathrm{Fe}(\mathrm{OH})_{3}+\mathrm{Cr}_{2} \mathrm{O}_{3}+6 \mathrm{SO}_{4}{ }^{2-}+29 \mathrm{H}_{2} \mathrm{O}+8 \mathrm{H}^{+}
$$

Another reducing agent that should reduce Cr(VI) is ferrous ammonium sulfate.

The reduction-oxidation reaction employing $\mathrm{Fe}\left(\mathrm{NH}_{4}\right)_{2}\left(\mathrm{SO}_{4}\right)_{2} \cdot 6 \mathrm{H}_{2} \mathrm{O}$ as the reducing agent is:

$$
\begin{gathered}
2 \mathrm{CrO}_{4}^{2-}+6 \mathrm{Fe}\left(\mathrm{NH}_{4}\right)_{2}\left(\mathrm{SO}_{4}\right)_{2} \cdot 6 \mathrm{H}_{2} \mathrm{O} \\
=\mathrm{Cr}_{2} \mathrm{O}_{3}+6 \mathrm{Fe}(\mathrm{OH})_{3}+23 \mathrm{H}_{2} \mathrm{O}+12 \mathrm{NH}_{4}^{+}+12 \mathrm{SO}_{4}{ }^{2-}+8 \mathrm{H}^{+}
\end{gathered}
$$

As shown in the reactions presented above, zero-valent iron and ferrous sulfide prefer an acidic environment for the reaction to proceed to the right. Conversely, ferrous sulfate and ferrous ammonium sulfate prefer an alkali environment for the reaction to proceed to the right.

\subsection{Solidification Theory}

The discussion on solidification theory will be limited to Portland cement. (Portland cement and cement hence forth are synonymous in this report.) Concrete hardens due to the hydration of the primary constituents in cement. As the constituents hydrate, crystals grow and form an interlocking web. The strength of concrete is gained by the formation and interlocking of these crystals. This process is relatively slow; concrete approaches its full strength in approximately 1 year. The main parameters that affect the properties of concrete are the water-to-cement ratio and the cement-tosoil/aggregate ratio. Cement requires approximately $1 / 4$ to $1 / 5$ of its weight in water to become completely hydrated and will not combine with more than approximately $1 / 2$ of the water in the mix (Orchard 1979). Therefore, the minimum water-to-cement ratio is 0.4 to 0.5 on a mass basis. Superplasticizers may be added to increase the workability or 
to decrease the amount of water necessary for hydration; however, superplasticizers are not discussed herein, because the objective of this study is not to produce a high-quality concrete but rather a low-cost, stabilized solid waste.

Although it is important for the cement to hydrate fully, adding extra water is detrimental; water in excess of that needed for hydration causes voids to form in the concrete that reduce the strength and increase the permeability of the concrete.

Figure 2-1 shows the relationship between the water-to-cement ratio and the cube strength. Increased permeability will cause an increase in contaminant leachability because the water will travel through the material more easily.

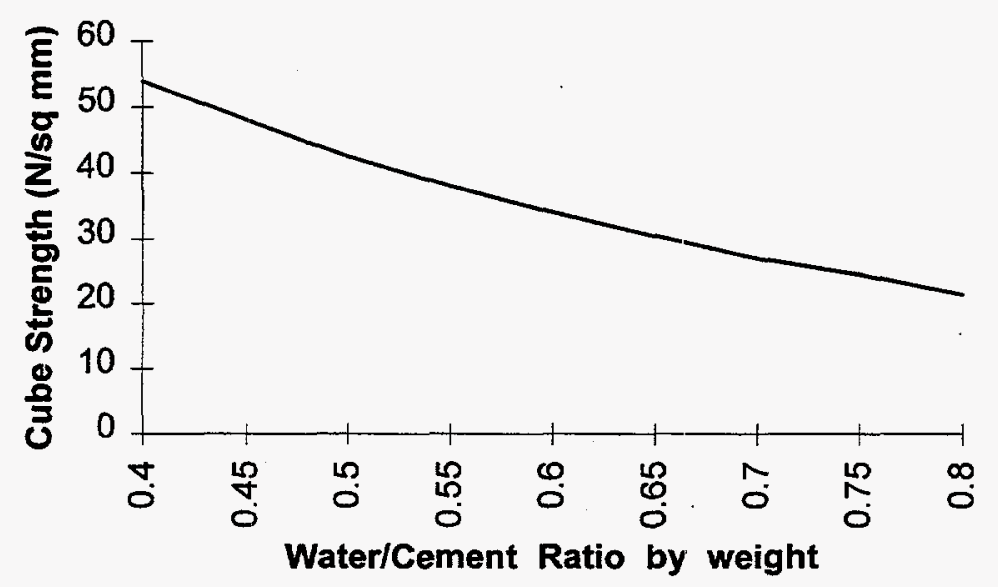

Figure 2-1. Relationship Between the Compressive Strength and the Water-to-Cement Ratio (after Lydon 1972)

Historically, proportions of cement, sand, and aggregate, have varied from 1:1:2 up to 1:4:8, respectively (Orchard 1979). For the purpose of creating a soil concrete, the ratios presented above become 1:3 and 1:12, for the proportions of cement and soil. The soil is composed of a mixture of sand, aggregate, clays, and silts. The ratio of these constituents is determined by the geology of the site. There is a wide range of cement-tosoil ratios that can be used; the proper ratio is dependent on the application. A smaller cement-to-soil ratio is required for solidification of hazardous wastes than for structural concrete because significantly less strength is required. Figure 2-2 shows the compressive strength as a function of cement content for a sandy gravel. This figure is for soil cements, which differ from soil concrete in that soil cements are compacted. However, the trend is indicative of the correlation between cement content and strength and applies to soil concretes. 


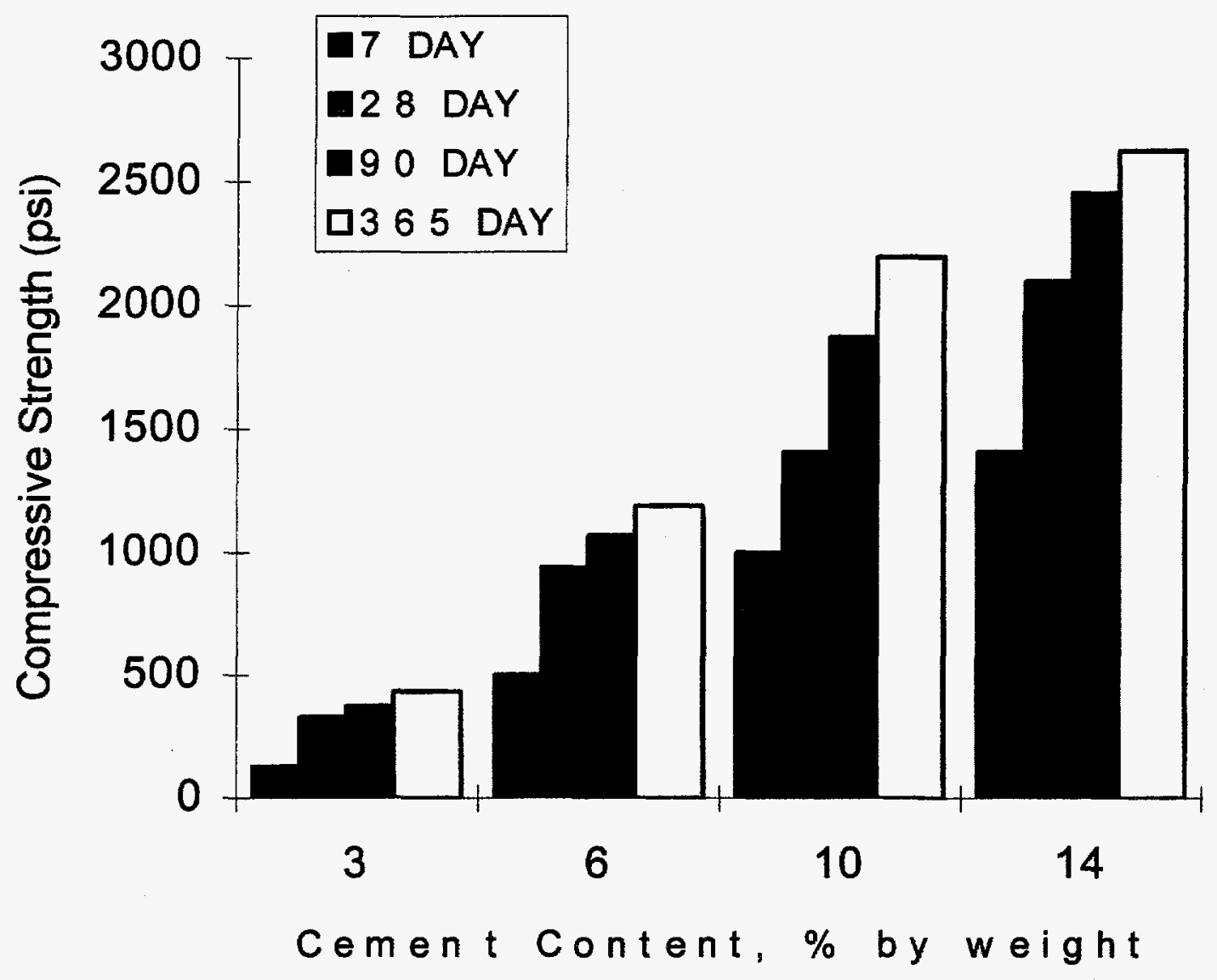

Figure 2-2. Compressive Strength as a Function of Cement Content and Time for a Sandy Gravel (Gillott 1968)

Cement is a successful solidification agent because the fibrillar matrix in the concrete incorporates the added aggregates and/or waste into a monolithic, rock-like mass (EPA 1980b). Another reason that cement is a successful solidification agent is that the solubility of $\mathrm{Cr}$ (III) is low in the $\mathrm{pH}$ range of concrete. The $\mathrm{pH}$ depends on the cement-to-soil ratio, but in general is approximately 10 to 12. As shown in Figure 1-2, $\mathrm{Cr}$ (III) solubility ranges from $10^{-12}$ to $10^{-10}$ moles per liter (M) in the $\mathrm{pH}$ range of 10 to 12. Figure 1-2 was created using the equations:

$$
\begin{array}{ll}
3 \mathrm{H}_{2} \mathrm{O}+2 \mathrm{Cr}^{3+}=\mathrm{Cr}_{2} \mathrm{O}_{3}+6 \mathrm{H}^{+} & \log \mathrm{K}=-12.7 \\
2 \mathrm{H}_{2} \mathrm{O}+2 \mathrm{Cr}^{3+}=\mathrm{Cr}(\mathrm{OH})_{2}^{-}+2 \mathrm{H}^{+} & \log \mathrm{K}=-43.3 \\
2 \mathrm{H}_{2} \mathrm{O}+\mathrm{Cr}^{3+}=\mathrm{CrO}_{2}^{+}+4 \mathrm{H}^{+} & \log \mathrm{K}=-28.0
\end{array}
$$

Kindness et al. (1994) suggest that cement is successful in immobilizing $\mathrm{Cr}(\mathrm{III})$, because the $\mathrm{Cr}(\mathrm{III})$ can be substituted for aluminum in most of the calcium aluminate hydrate phases. 


\section{Methods}

This section describes the methods used to complete this investigation. EPA and ASTM test methods were used whenever possible. Appendix A presents the methods in tabular form.

\subsection{Soil Retrieval and Testing for Transportation}

Soil samples were retrieved with an auger rig from a depth of 8 to $30 \mathrm{ft}$ bgs and placed in 5-gallon (gal.) hazardous waste buckets. The original target depth to obtain samples was from 10 to $20 \mathrm{ft}$ bgs; only one hole could be augered, so it was extended to $30 \mathrm{ft}$ bgs to obtain enough soil for the study. Collected soil was analyzed for metals and volatile organic compounds (VOCs) at the SNL/NM field laboratory before shipment to the University of New Mexico. Table 2-1 presents the soil analysis data provided by the SNL/NM field laboratory. Figure 1-3 shows the total chromium concentration with depth determined by X-ray fluorescence (XRF) analysis.

\subsection{Soil Physical Tests}

Soil physical tests were performed to characterize the soil. The test methods described in this section include those for soil moisture, sieve analysis, soil absorption, and loose bulk density. Sections 4.1 through 4.1 .4 present the test results.

\subsubsection{Soil Moisture}

In accordance with ASTM D2216-92 (ASTM 1995b), the soil moisture was determined for four samples taken at the following depths: 8 to $10 \mathrm{ft} \mathrm{bgs,}, 15$ to $17 \mathrm{ft} \mathrm{bgs,} 20$ to $21 \mathrm{ft} \mathrm{bgs}$, and 26 to $28 \mathrm{ft}$ bgs.

\subsubsection{Sieve Analysis}

Sieve analysis was performed on the composited material using the Bowles (1992) test method; this method combines more than two applicable ASTM and American Association of State Highway and Transportation Officials (AASHTO) procedures in a user-friendly document. The soil was not washed, as required by the procedure, to prevent $\mathrm{Cr}(\mathrm{VI})$ removal from the soil.

\subsubsection{Soil Absorption}

Soil absorption was determined using procedure ASTM C128-93 (ASTM 1995c). This procedure was performed on the three soil classifications defined in Section 3.2. 


\subsubsection{Loose Bulk Density}

It was necessary to determine the bulk density of the soil to estimate the quantity of soil for the first batch of soil concrete. The loose bulk density was determined by weighing a 5-gal. bucket containing soil, measuring the volume of water needed to fill the bucket to the same level, subtracting the weight of the bucket, and then dividing the soil weight by this volume.

\subsection{Total Chromium Analysis}

Total chromium was determined on a Perkin-Elmer Model 460 Atomic Absorption (AA) Spectrophotometer using a flame in accordance with EPA Method 7190.

\subsection{Colorimetric Analysis for Chromium (VI)}

The presence of $\mathrm{Cr}(\mathrm{VI})$ was determined using EPA. Method 7196A. This procedure involves acidification to a $\mathrm{pH}$ of $2.0 \pm 0.5$ using sulfuric acid and addition of a colorimetric reagent, diphenylcarbazide solution. The samples were analyzed for $\mathrm{Cr}(\mathrm{VI})$ on a Bausch \& Lomb Spectronic 88 colorimetric spectrophotometer. If $\mathrm{Cr}(\mathrm{VI})$ is present, the solution turns a red-violet color that is proportional to the $\mathrm{Cr}(\mathrm{VI})$ concentration.

\subsection{Reduction Experiments}

One goal of this study was to minimize the leaching of $\mathrm{Cr}$ (VI) from contaminated soil. The first step in obtaining this goal was to find a satisfactory reducing agent that can reduce the $\mathrm{Cr}(\mathrm{VI})$ at high $\mathrm{pH}$ (e.g., 8 to 10 ) in a relatively short period of time.

Batch studies were chosen as the most appropriate means to determine an effective reducing agent. The batch studies were conducted using 30-milliliter $(\mathrm{ml})$ and $40-\mathrm{ml}$ glass vials with screw caps and 130-ml glass sample bottles with rubber stoppers. The 30-ml and 40-ml glass vials were used with the following reducing agents: iron powder, iron filings, ferrous sulfide, ferrous sulfate, and ferrous ammonium sulfate. The $130-\mathrm{ml}$ glass sample bottles were used to accommodate a large volume of steel wool.

At the beginning of the study, a $50-\mathrm{mg} / \mathrm{l} \mathrm{Cr}$ (VI) solution was prepared by dissolving $141.4 \mathrm{mg}$ of dried potassium dichromate in 1 liter (1) of deionized water (DI water). The above solution was replaced with a $1000-\mathrm{mg} / \mathrm{l} \mathrm{Cr}$ (VI) Baker ${ }^{\circledR}$ analyzed AA standard prepared from ammonium dichromate halfway through the reduction experiments. This replacement was done to ensure the highest quality standard. $\mathrm{Cr}(\mathrm{VII})$ solutions were prepared by diluting the $1000-\mathrm{mg} / 1$ stock solution.

In batch studies, $20 \mathrm{ml}$ of $\mathrm{Cr}(\mathrm{VI})$ solution was poured into $30-\mathrm{ml}$ and $40-\mathrm{ml}$ vials, and $100 \mathrm{ml}$ of $\mathrm{Cr}(\mathrm{VI})$ solution was poured into $130-\mathrm{ml}$ sample bottles. The concentrations of the solutions ranged from $10 \mathrm{mg} / 1$ to $1000 \mathrm{mg} / 1$. After reduction experiment 11 , tap water was used 
to prepare the batch experiments for the remainder of this study because tap water would be used to make the soil concrete. DI water was used throughout the study in preparation of AA standards. The $\mathrm{pH}$ was adjusted using dilute and concentrated sulfuric acid, dilute and concentrated ammonium hydroxide solutions, and dilute and concentrated sodium hydroxide solutions.

The reducing agents were added as molar ratios of reducing agent to $\mathrm{Cr}(\mathrm{VI})$, except for steel wool and blast furnace slag. After addition of zero-valent iron and ferrous sulfide, the samples were shaken vigorously for approximately 3 seconds (sec), then placed on a daisy wheel, roller, or wrist shaker. Use of the wrist shaker was discontinued after reduction experiment 2, except for use with steel wool, because it could not keep the iron powder in suspension. After addition of ferrous sulfate and ferrous ammonium sulfate, the samples were shaken for 2 to 5 seconds. Initially, the samples containing ferrous sulfate and ferrous ammonium sulfate were placed on the counter to observe effects. Later, the samples were filtered immediately to reduce contact time. Uncontaminated soil was added to the last three batch experiments to determine whether there were any synergistic or antagonistic effects. All batch samples were filtered through a No. 41 Whatman ${ }^{\circledR}$ filter before analysis. (Section 4.2 presents the reduction experiment results. Tables 4-4 through 4-7 describe the experimental conditions of the batch tests.)

\subsection{Soil Chemical Tests}

Soil chemical tests were performed to characterize the chromium contamination in the soil. Test methods described in this section include those for chromium concentration and speciation, sulfate concentration, $\mathrm{pH}$, and the TCLP. (Sections 4.3 through 4.3.5 present the results for the soil chemical tests.)

\subsubsection{Chromium Concentration and Speciation with Depth}

By measuring the total chromium [Cr(VI) and $\mathrm{Cr}(\mathrm{III})]$ and the water-soluble chromium [Cr(VI)], chromium concentration and speciation were determined in three samples taken at the following depths: 10 to $13 \mathrm{ft} \mathrm{bgs,} 20$ to $21 \mathrm{ft}$ bgs, and 26 to $28 \mathrm{ft}$ bgs. The soil particle size used in the digestion and water leach experiments was smaller than a No. 10 sieve ( 2.0 millimeters $[\mathrm{mm}]$ ), and most was smaller than a No. 40 sieve [ 425 micrometers $(\mu \mathrm{m})$ ]. Soil samples were prepared by acid digestion, and the total chromium was determined in accordance with EPA Methods 3050A and 7190.

Water-soluble chromium was determined using soil samples weighing between 1.0 and 2.0 grams $(\mathrm{g})$. Three soil samples were used from the field samples taken at the following depths: 10 to $13 \mathrm{ft}$ bgs, 20 to $21 \mathrm{ft} \mathrm{bgs,} \mathrm{and} 26$ to $28 \mathrm{ft}$ bgs. The 10 - to $13-\mathrm{ft}$ bgs samples were combined with $40 \mathrm{ml}$ of DI water in $125-\mathrm{ml}$ Erlenmeyer flasks. The 20- to $21-\mathrm{ft}$ bgs and 26- to $28-\mathrm{ft}$ bgs samples were combined with $50 \mathrm{ml}$ of DI water in $125-\mathrm{ml}$ Erlenmeyer flasks. Except when a sample was taken, the flasks were placed in a wrist shaker and shaken constantly. Samples were analyzed for chromium using EPA Method 7190 at 24 hours (hr) and $48 \mathrm{hr}$. 


\subsubsection{Soil Compositing and Partitioning}

After determining the concentration and speciation with depth, the samples were composited in a 4-cubic-foot $\left(\mathrm{ft}^{3}\right)$ cement mixer to provide homogeneous soil for subsequent testing. Approximately $1 / 2$ of the soil was run through a No. 100 sieve for parallel study of the fine-grained soil. This paper refers to three soil classifications: minus 100 soil (passed the No. 100 sieve), composite soil (the original soil), and plus 100 soil (did not pass the No. 100 sieve).

\subsubsection{Chromium Concentration and Speciation in the Three Soil Classifications}

The minus 100 , composite, and plus 100 soil samples were analyzed for total chromium and water-leachable chromium following EPA Method 7190. The soil used in the digestion and water leach experiments was smaller than a No. 10 sieve $(2.0 \mathrm{~mm})$ and most was smaller than a No. 40 sieve $(425 \mu \mathrm{m})$.

The water leach experiments for the composite soil. were conducted by combining soil samples and $75 \mathrm{ml}$ of DI water in 125-ml Erlenmeyer flasks. Minus 100 and plus 100 soil water leach experiments were conducted by combining soil samples and $50 \mathrm{ml}$ of DI water in $125-\mathrm{ml}$ Erlenmeyer flasks. Six composite, three minus 100, and three plus 100 soil samples were subjected to the water leach experiments.

Soil samples weighed between 1.0 and $2.0 \mathrm{~g}$. Samples were initially leached for $96 \mathrm{hr}$, until analysis showed that $72 \mathrm{hr}$ produced equivalent results.

\subsubsection{Sulfate Concentration}

The sulfate concentration of the three soil classifications was determined by analysis on a Dionex 2010i ion chromatograph.

\subsection{5 $\mathrm{pH}$ Values}

The $\mathrm{pH}$ of the three soil classifications was determined by filling a 250 -ml beaker halfway with soil and then adding DI water to approximately $1 / 2$ inch (in.) above the soil. This mix was stirred for a few minutes and then allowed to set for 15 minutes. The $\mathrm{pH}$ probe was inserted to approximately $1 \mathrm{in}$. below the surface of the water.

\subsubsection{Soil Toxicity Characteristic Leaching Procedure}

It was necessary to determine whether the soil was considered hazardous waste due to the amount of chromium leachable from the soil. The method used to determine this is specified in RCRA, Part 261, Appendix II, Method 1311, TCLP, using extraction fluid number 2. Soil samples were run through a $9.423-\mathrm{mm}$ sieve as part of the test, and the TCLP extracts were initially digested per EPA Method 3010A. 
A clause in the EPA digestion procedure states that "TCLP extracts to be analyzed for metals shall be acid digested except in those instances where digestion causes loss of metallic analytes." In all but one digestion, the undigested concentration was equal to or greater than the digested concentration. Figure 3-1 presents these data in a scatter plot.

The slope of the line in the Figure 3-1 scatter plot is approximately 1. Data points below the line indicate that the chromium concentration decreased with digestion. All but one data point lies on or below the line, demonstrating that digestion was not required.

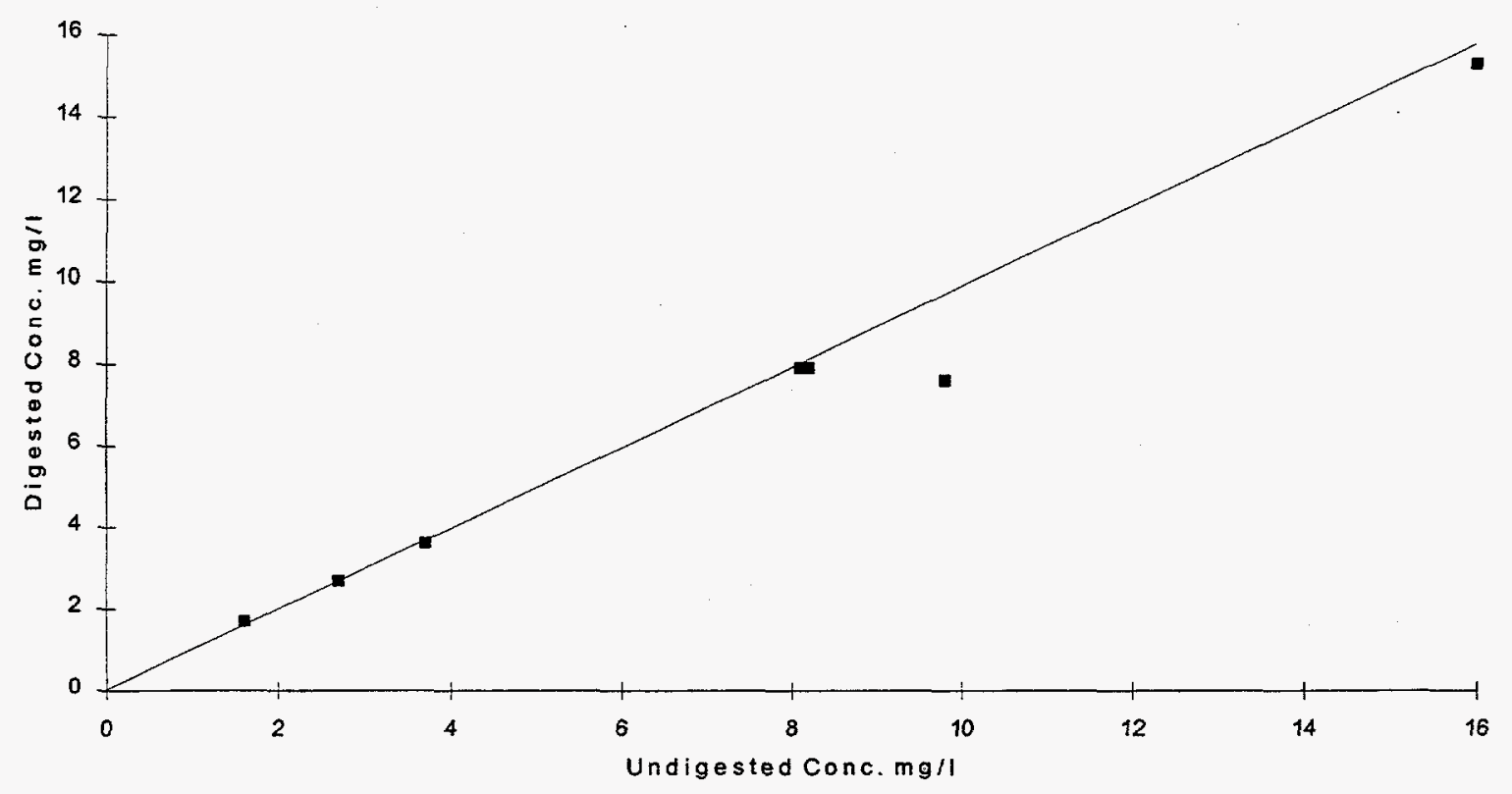

Figure 3-1. Scatter Plot Showing the Relationship Between Undigested and Digested Toxicity Characteristic Leaching Procedure Extract Concentrations. The line indicates a slope of 1 .

\subsubsection{Sample Verification}

A soil sample from each of the three soil classifications was sent to General Engineering Laboratories (GEL) of Charleston, South Carolina, for TCLP analysis to verify results obtained at the University of New Mexico (UNM) in Albuquerque. 


\subsection{Mortar Mixer Experiments}

Before making the first batch of soil concrete, it was necessary to determine whether the reduction process would be successful in a 5-quart (qt) mortar mixer set on the lowest speed. All rocks larger than 1 inch in any dimension were removed from these mixing bowl reduction experiments to conform with ASTM C192-90a (ASTM 1995c).

To test the reduction process, a set of experiments was conducted using ferrous sulfate as the reducing agent. In the first experiment, 23 pounds $(\mathrm{lb})(10.4 \mathrm{~kg})$ of soil were wetted with $1402 \mathrm{~g}$ of tap water. The wet soil was mixed for 1 to 2 minutes to ensure equal moisture distribution throughout the sample. After adding $79.0 \mathrm{~g}$ of ferrous sulfate, the soil was mixed for another 2 minutes; this amount of ferrous sulfate provided a 4.4 molar ratio of ferrous sulfate to $\mathrm{Cr}(\mathrm{VI})$ for the highest concentration of $\mathrm{Cr}(\mathrm{VI})$ in the soil as determined by the leaching experiments. The ratio of 4.4 moles of ferrous sulfate per mole of chromium was used, based on reduction experiment data. A grab sample consisting of soil and water was filtered through a No. 41 Whatman ${ }^{\circledR}$ filter and subjected to colorimetric analysis.

The purpose of the second experiment was to determine the effects of no reducing agent on $\mathrm{Cr}(\mathrm{VI})$ concentrations. In this experiment, $10 \mathrm{lb}(4.5 \mathrm{~kg})$ of soil was wetted with $853.7 \mathrm{~g}$ of tap water and mixed for 1 to 2 minutes to ensure equal moisture distribution. A grab sample was prepared and analyzed using the same procedure as that described for the first batch.

Using the same soil as in the previous experiment, $33.0 \mathrm{~g}$ of ferrous sulfate [ 4.4 molar ratio ferrous sulfate to $\mathrm{Cr}(\mathrm{VI})]$ was added to the soil-water mix and mixed for 1 minute. A grab sample was taken and analyzed as done previously. An additional $33.0 \mathrm{~g}$ of ferrous sulfate was added to determine the effects of additional reducing agent.

The final experiment was conducted to measure the effects of reducing the amount of ferrous sulfate added to the mix to treat the average Cr(VI) concentration in the soil. After $10 \mathrm{lb}$ $(4.5 \mathrm{~kg})$ of soil were wetted with $849.7 \mathrm{~g}$ of tap water, $29.2 \mathrm{~g}$ of ferrous sulfate were added and mixed for 1 minute. A grab sample was taken and analyzed for $\mathrm{Cr}(\mathrm{VI})$ as done previously. (Section 4.4 presents the results of the mortar mixer experiments.) 


\subsection{Soil Concrete Methods and Tests}

ASTM methods were used in the preparation and physical testing of the soil concrete to provide a comparison with other work. The soil concrete was subjected to the TCLP following the physical tests. Sections 4.5 through 4.9 present the experiment and TCLP results.

\subsubsection{Soil Concrete Preparation}

The soil concrete was prepared and cured in accordance with ASTM C192-90a (ASTM 1995c). Because of the range of the unconfined compression testing machines and the quantity of attainable soil, 3-in.-diameter by 6-in.-long cylinders were chosen as the specimen size. The concrete was cured in plastic molds with taped lids on a level, vibration-free surface.

\subsubsection{Soil Concrete Strength Testing}

Soil concrete samples were strength tested at 3, 7, and 28 days in accordance with ASTM C39-93a (ASTM 1995c). When it was possible, three samples were tested at each time interval. The samples were tested on calibrated Tinius Olsen and Riehle Testing machines. Some samples required sanding to meet the parallelism requirement, i.e., the ends of compressive test samples shall not depart from perpendicularity to the longitudinal axis by more than 0.5 degree.

\subsubsection{Soil Concrete Testing Using the Toxicity Characteristic Leaching Procedure}

The soil concrete TCLP tests were accomplished using the same EPA procedure and extraction fluid as the soil TCLP test. Soil concrete samples were broken with a chisel and a 4-lb sledgehammer, and an effort was made to split the samples longitudinally down the center. The large split-off chunk of the monolith was then crushed in preparation for the $9.423-\mathrm{mm}$ sieving. An attempt was made to use equal amounts of very fine and large material for the TCLP. Figures 3-2 through 3-4 show the preparation of the soil concrete for the TCLP.

The TCLP extracts were initially digested in accordance with EPA Method 3010A. TCLP extracts were analyzed for total chromium in accordance with EPA Method 7190 and for $\operatorname{Cr}(V I)$ using EPA Method 7196A.

Samples with concentrations reported as $0.05 \mathrm{mg} / \mathrm{l}$ of total chromium were below the detection limit of $0.1 \mathrm{mg} / 1$ of total chromium. All other TCLP data were rounded to the nearest $0.1 \mathrm{mg} / 1$ of total chromium.

\subsubsection{Verification}

One sample from each batch 18 and 19 was sent to GEL for the TCLP analysis to verify results obtained at UNM. 

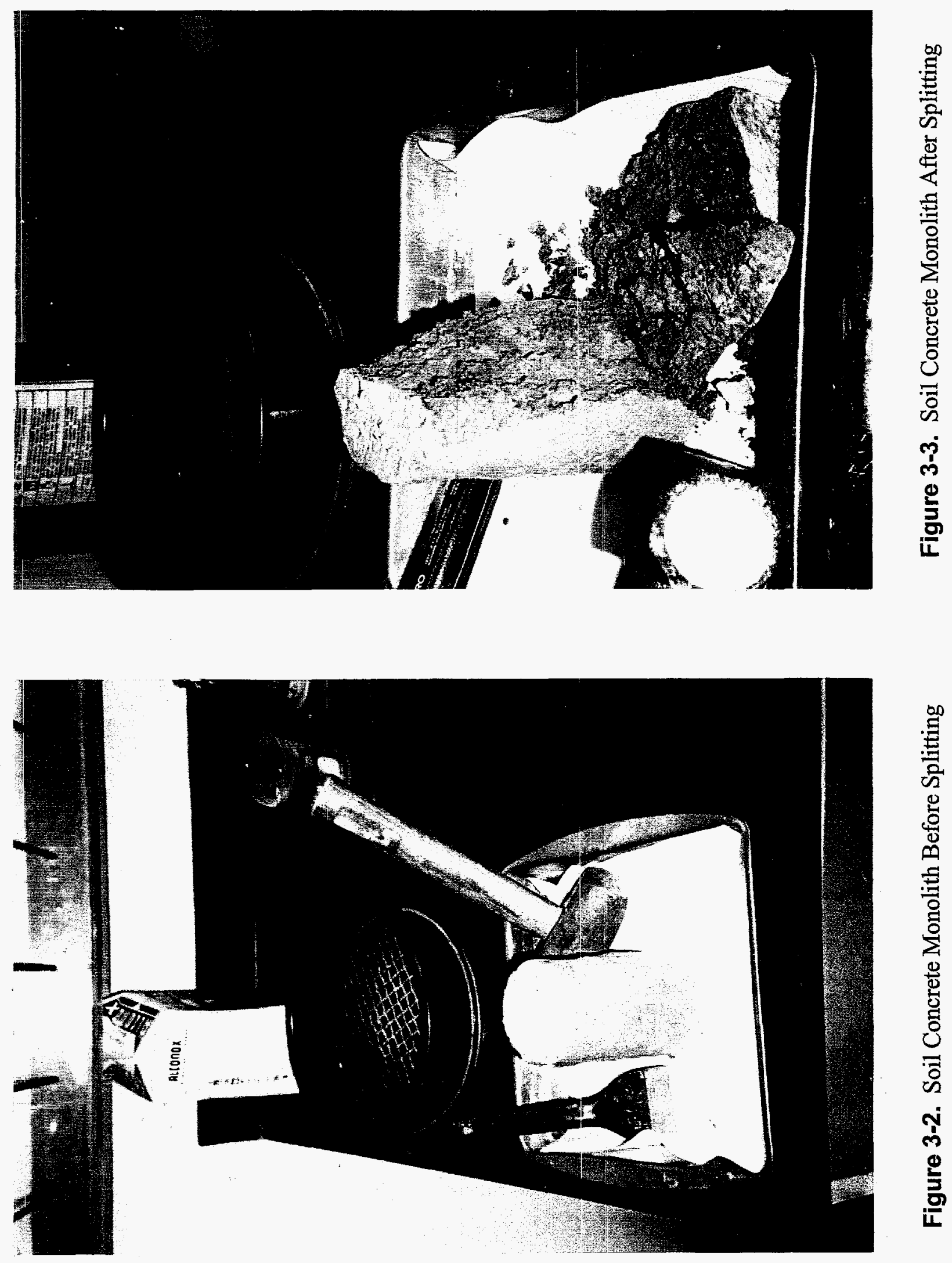

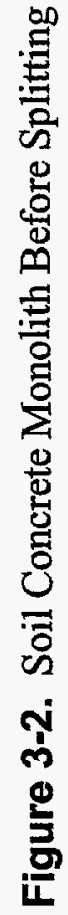




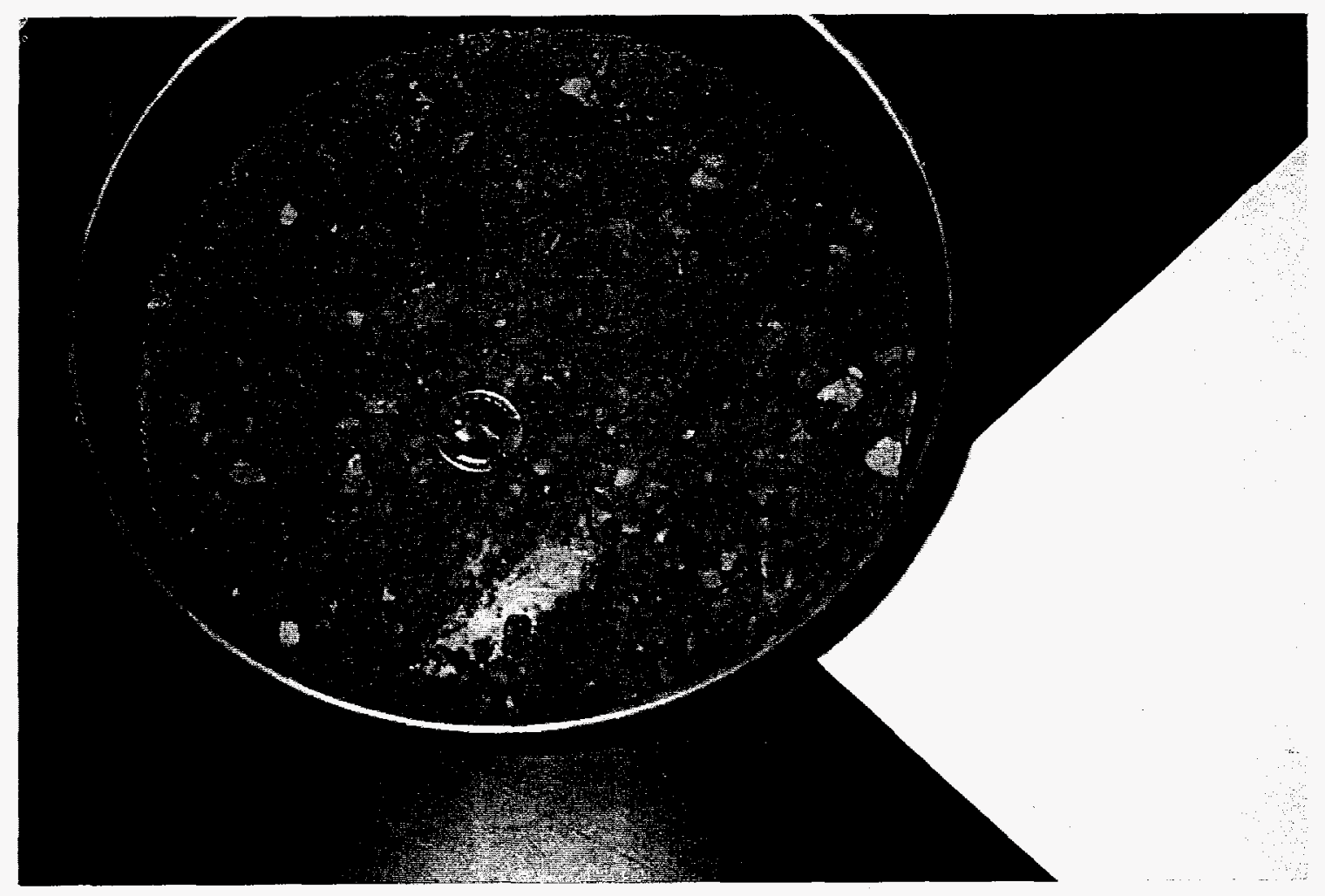

Figure 3-4. Crushed Soil Concrete Ready for the Toxicity Characteristic Leaching Procedure 


\subsection{Preliminary Soil Concrete Batches}

After satisfactory Cr(VI) reduction in mortar mixer experiments, the next step was to add cement to the soil to make soil concrete. The cement used in this study was Portland Cement Type 5, provided by Rio Grande Portland Cement Corporation. For the remainder of this paper, "cement" indicates Type 5 Portland cement.

Prior to receiving the contaminated soil for study, four initial batches of soil concrete were made using uncontaminated soil collected approximately 200 yards from the contaminated soil location. The physical characteristics of the soils were assumed to be the same. Two batches of soil concrete were made using composite soil and 15 percent cement (weight per weight [w/w]). One batch of soil concrete was made using minus 100 soil and 15 percent cement $(\mathrm{w} / \mathrm{w})$. One batch of soil concrete was made using plus 100 soil and 8 percent cement $(w / w)$. These batches were made to estimate the quantity of cement needed to solidify the contaminated soil, thereby reducing the amount of contaminated soil required for the study.

\subsection{Parameter Optimization}

Data from the uncontaminated samples proved useful in determining the appropriate ratio of cement to use for the contaminated soil. This was the first of three steps in the optimization process. The parameters optimized in this process were: the cement-to-soil ratio, the sodium silicate-to-cement ratio, and the reducing agent-to-soil ratio. The optimization process was based on data from two tests: strength testing and the TCLP test. Figure 3-5 shows this process in flowchart form. 


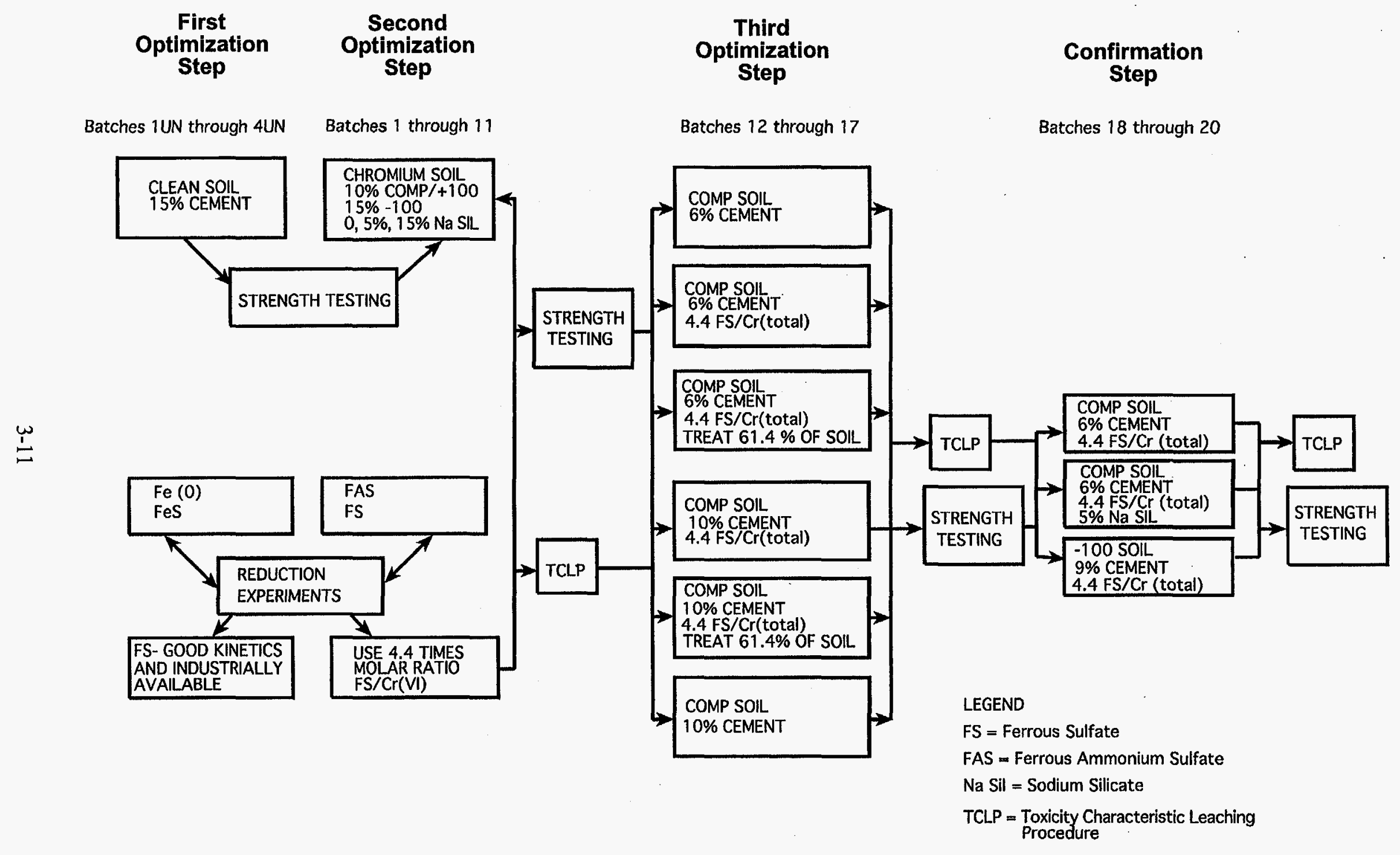

Figure 3-5. Optimization Process Flowchart 


\subsubsection{Second Optimization Step: Batches 1 through 11}

Cement was added to the contaminated soil in the ratio of 10 percent cement to soil (w/w) for batches 1 through 11, except for batch 4 because it was made with minus 100 soil. The other batches were made with composite soil and plus 100 soil. Water was added to batches. 1 through 7 to obtain a water-to-cement ratio of $0.4(\mathrm{w} / \mathrm{w})$ based on the soil absorption test. Table 3-1 shows the composition of the soil concrete for the second optimization step.

Batches 1 through 7 were too stiff to be used in a waste treatment process. The soil concrete would not pour and had to be dug out of the mixing bowl. Because one goal of this study was to provide bench-scale data for field processing, batches 8 through 11 were similar to batches 1 through 7, except more water was added to make them just pourable, but not selfleveling.

Ferrous sulfate and sodium silicate were added to the soil cement to reduce the chromium and increase the siliceous material, respectively. In the first set of soil concrete batches (1 through 11), ferrous sulfate was added in the ratio of 4.4 moles of ferrous sulfate per mole of $\mathrm{Cr}(\mathrm{VI})$ in the soil. The amount of $\mathrm{Cr}(\mathrm{VI})$ treated was the average concentration determined by the water leach study. Ferrous sulfate was added to the wetted soil and mixed for 1 minute. It was necessary to add enough water so that it ponded on top of the soil.

Sodium silicate was added to the initial set of soil concrete batches as a percent of the cement added $(\mathrm{w} / \mathrm{w})$. The amounts added were 0,5 , and 15 percent. Table $3-1$ shows the composition of each soil concrete batch. 
Table 3-1. Composition of Batches 1 through 11

\begin{tabular}{|c|c|c|c|}
\hline $\begin{array}{l}\text { Batch } \\
\text { Number }\end{array}$ & Soil Type & $\begin{array}{c}\text { Percent } \\
\text { Cement }(w / w)\end{array}$ & $\begin{array}{l}\text { Percent Sodium } \\
\text { Silicate }(w / w)\end{array}$ \\
\hline 1 & Composite & 10 & 0 \\
\hline 2 & Composite & 10 & 5 \\
\hline 3 & Composite & 10 & 15 \\
\hline 4 & -100 & 15 & 0 \\
\hline 5 & +100 & 10 & 0 \\
\hline 6 & +100 & 10 & 5 \\
\hline 7 & +100 & 10 & 15 \\
\hline 8 & Composite & 10 & 0 \\
\hline 9 & Composite & 10 & 5 \\
\hline 10 & +100 & 10 & 5 \\
\hline 11 & Composite & 10 & 15 \\
\hline \multicolumn{4}{|c|}{$\begin{array}{l}\text { Note: Ferrous sulfate was added to treat the average } \mathrm{Cr}(\mathrm{VT}) \\
\text { concentration in the soil in the ratio of } 4.4 \text { moles of ferrous } \\
\text { sulfate per mole of chromium. }\end{array}$} \\
\hline
\end{tabular}

\subsubsection{Third Optimization Step: Batches 12 through 17}

Batches 12 through 17 were made using the data acquired from batches 1 through 11 . Water was added to make the fresh soil concrete just pourable, but not self-leveling.

A lower ratio of cement was implemented, 6 percent, but 10 percent cement to soil (w/w) was maintained in three batches for continuity between batch sets. More ferrous sulfate was used to reduce the amount of $\mathrm{Cr}(\mathrm{VI})$ in the TCLP extract. Ferrous sulfate was added in the ratio of 4.4 moles of ferrous sulfate per mole of total chromium in the soil and 4.4 moles of ferrous sulfate per mole of total chromium in 61.4 percent of the soil. The number 61.4 percent comes from sieve analysis data showing that 38.6 percent of the soil was gravel. Gravel was assumed to not 
contain any chromium. In the initial batches (batches 1-11), ferrous sulfate was added to treat $\mathrm{Cr}(\mathrm{VI})$ only. Sodium silicate was not added to these batches of soil concrete. Only four samples were made for each of these batches because of the limited supply of soil and confidence that the necessary information would be provided. Table 3-2 shows the composition of batches 12 through 17.

Table 3-2. Composition of Batches 12 through 17

\begin{tabular}{|c|c|c|}
\hline Batch Number & $\begin{array}{c}\text { Percent Cement } \\
\text { (w/w) }\end{array}$ & Ferrous Sulfate \\
\hline 12 & 10 & 0 \\
\hline 13 & 10 & To treat $100 \%$ of soil \\
\hline 14 & 10 & To treat $61.4 \%$ of soil \\
\hline 15 & 6 & To treat $100 \%$ of soil \\
\hline 16 & 6 & To treat $61.4 \%$ of soil \\
\hline 17 & 6 & 0 \\
\hline Note: $\begin{array}{l}\text { All batches were made with composite soil and sodium } \\
\text { silicate was not added to any of the batches. Ferrous } \\
\text { sulfate was added to treat the average total chromium in the } \\
\text { ratio of } 4.4 \text { moles of ferrous sulfate per mole chromium. }\end{array}$ \\
\hline
\end{tabular}

\subsubsection{Confirmation Step: Batches 18, 19, and 20}

Review of the TCLP and strength data showed that batch 15 had the optimal proportions of components. A final set of batches, 18 through 20, was made to parallel batch 15. An attempt was made to match the water quantities; however, it was difficult to control due to slight variances in soil composition/absorption and the addition of sodium silicate in batch 19 . Batch 15 was successfully reproduced in batches 18 and 19 except for the addition of 5 percent sodium silicate to cement (w/w) in Batch 19. Batch 20 was made with the remaining minus 100 soil $(4.2 \mathrm{lb})(1.9 \mathrm{~kg})$ and 9 percent cement. An extra 3 percent cement to soil $(\mathrm{w} / \mathrm{w})$ was added based on previous data. Figures 3-6 through 3-9 show steps in the mixing process for batches 18 and 19, and Table 3-3 shows the composition of batches 18, 19, and 20 . 


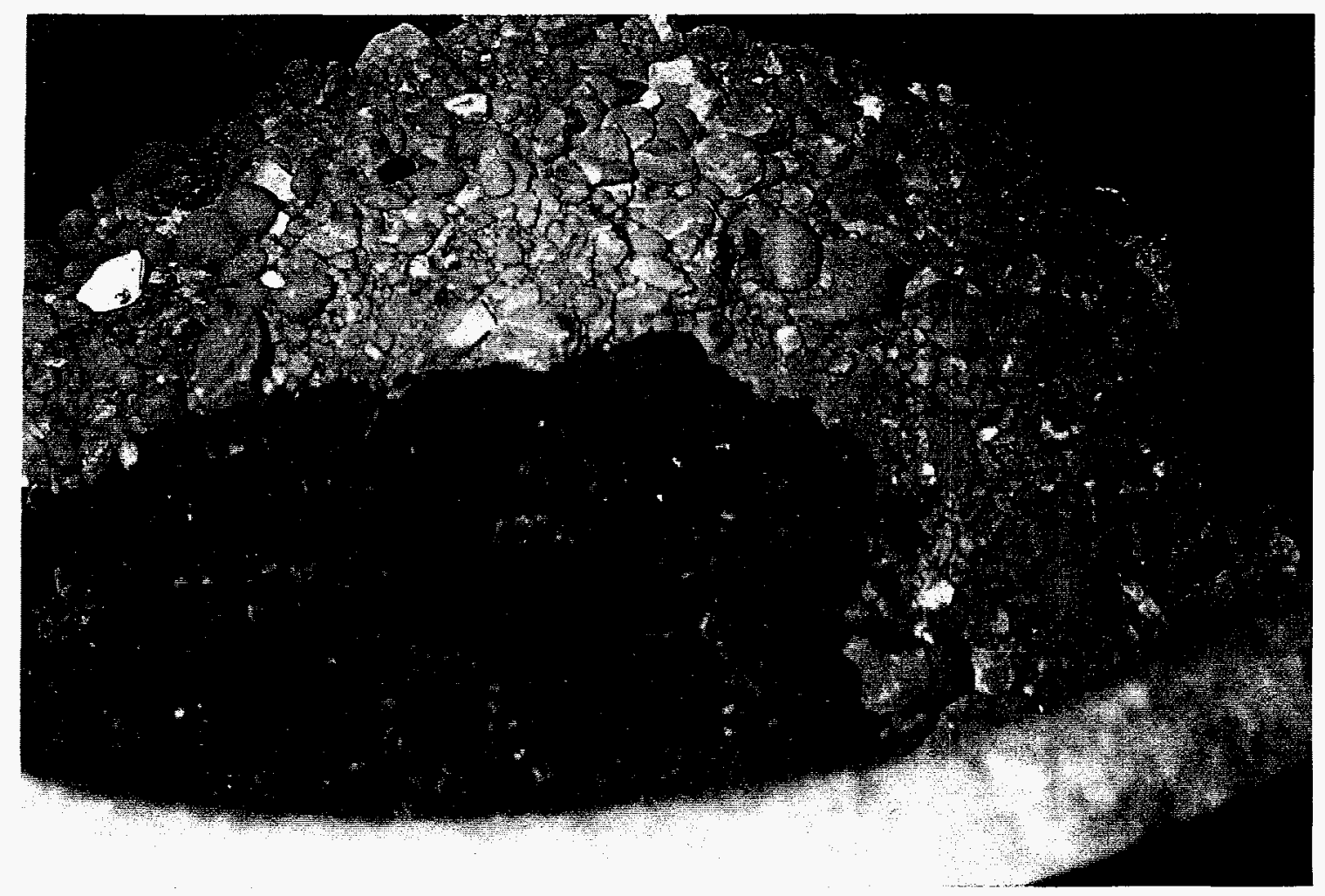

Figure 3-6. Water Added to the Soil

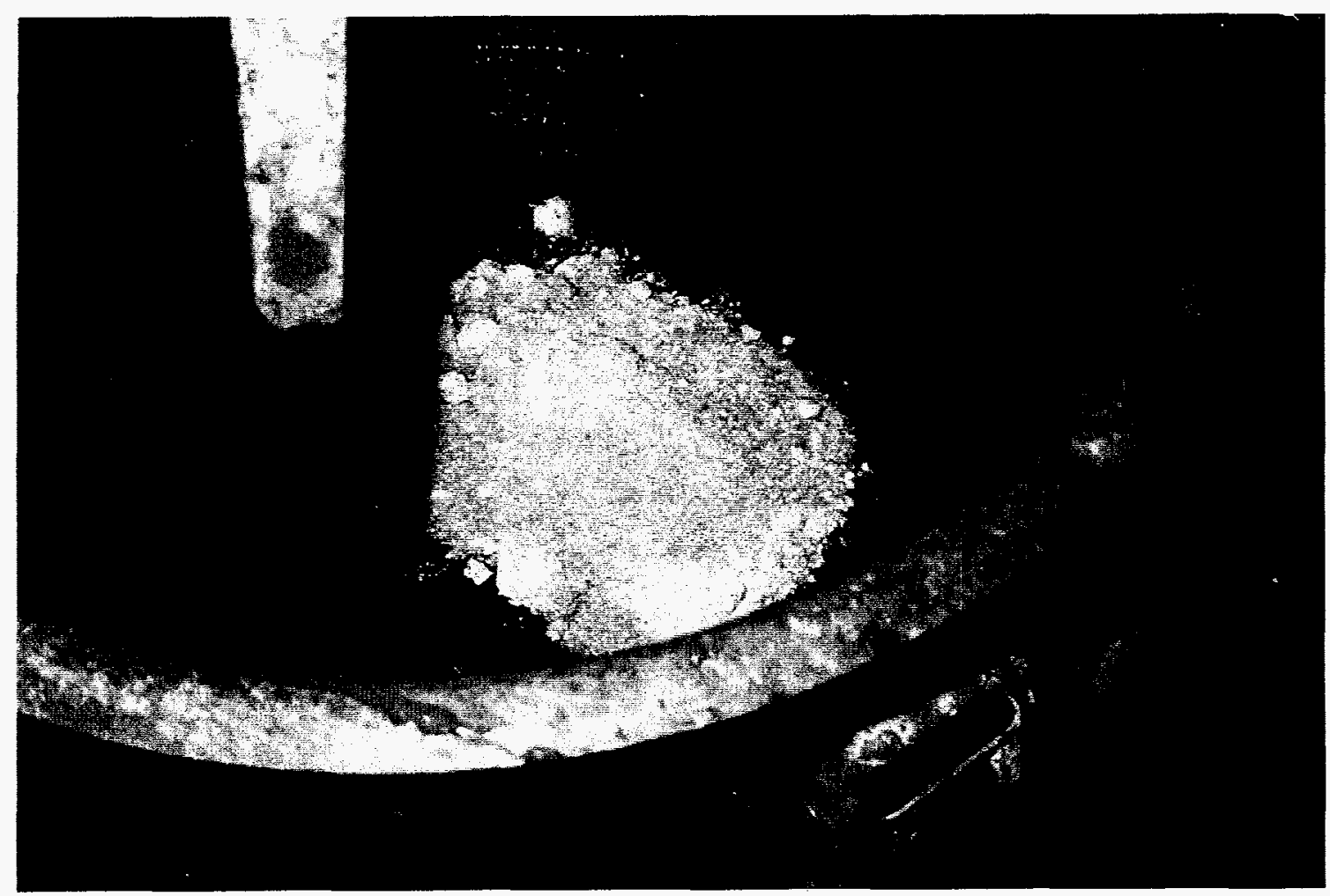

Figure 3-7. Addition of Ferrous Sulfate to Batch 18 


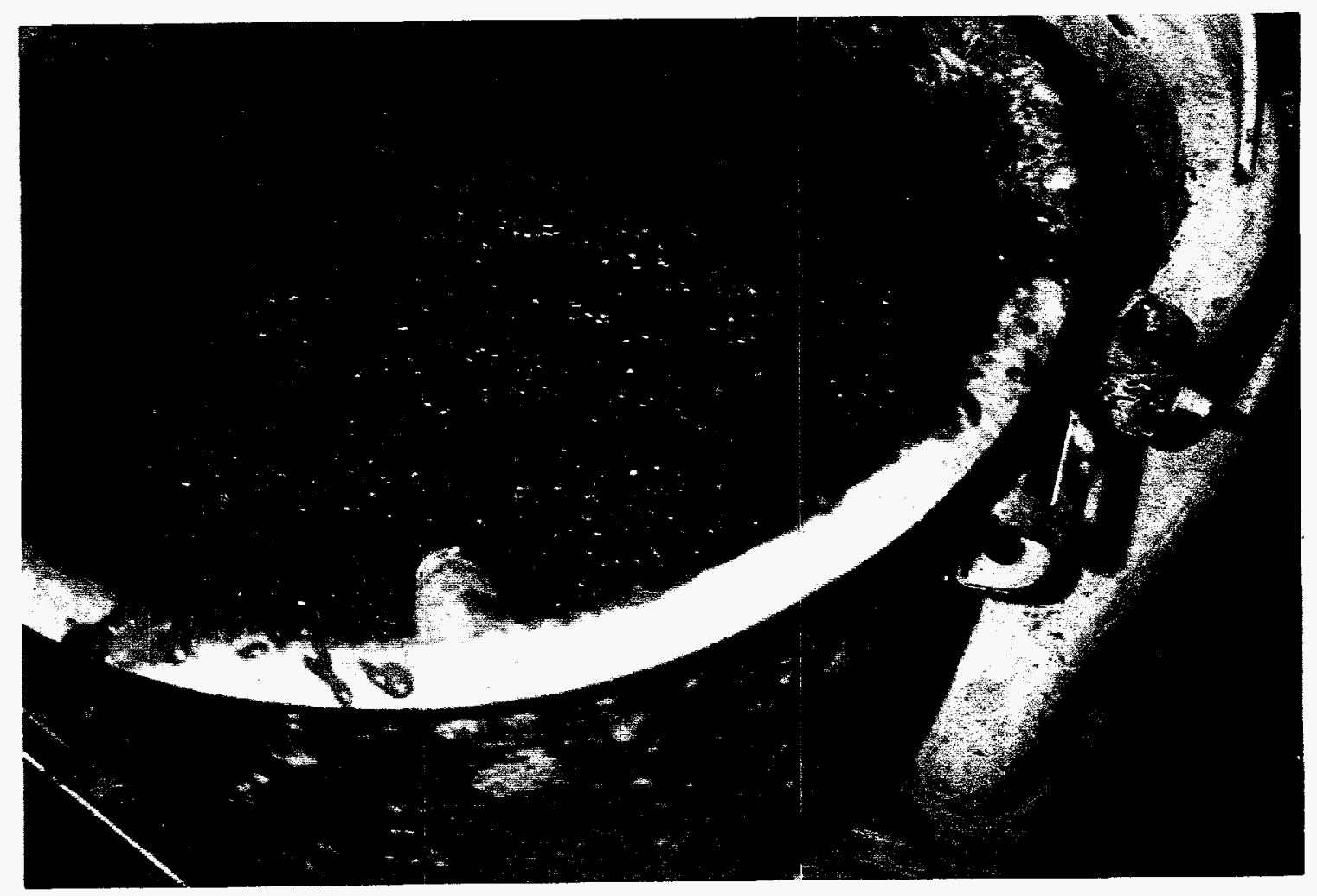

Figure 3-8. Prepared Soil Concrete Ready to be Placed into Molds

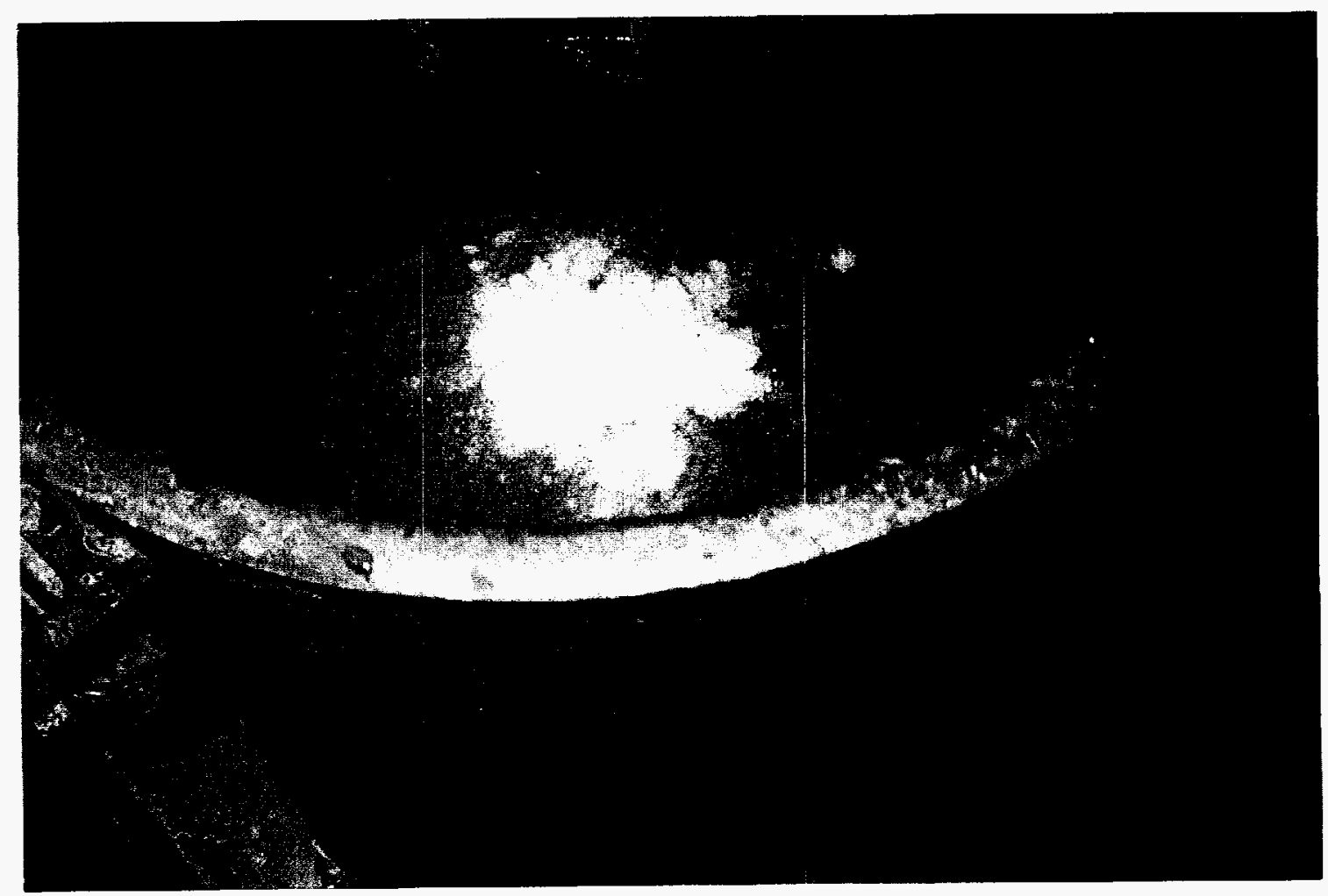

Figure 3-9. Addition of Cement and Sodium Silicate to Batch 19 
Table 3-3. Composition of Batches 18, 19, and 20

\begin{tabular}{|c|c|c|c|}
\hline $\begin{array}{c}\text { Batch } \\
\text { Number }\end{array}$ & Soil Type & $\begin{array}{c}\text { Percent } \\
\text { Cement (w/w) }\end{array}$ & $\begin{array}{c}\text { Percent } \\
\text { Sodium } \\
\text { Silicate }\end{array}$ \\
\hline 18 & Composite & 6 & 0 \\
\hline 19 & Composite & 6 & 5 \\
\hline 20 & -100 & 9 & 0 \\
\hline Note: $\begin{array}{c}\text { Ferrous sulfate was added to treat the average total } \\
\text { chromium concentration in 100 percent of the soil in the } \\
\text { ratio of 4.4 moles of ferrous sulfate per mole of chromium. }\end{array}$ \\
\hline
\end{tabular}

\subsection{Bulk Density}

The bulk density of the soil concrete was determined by weighing each monolith and dividing the weight by the volume of the 3-in.-diameter by 6-in.-long mold. (Section 4.11 presents the results.) 


\section{Results}

The data in this section are presented in parallel with the methods described in Section 3.0. This should provide easy reference between sections.

\subsection{Soil Physical Data}

Small variations in soil physical data could affect treatment. The amount of water required for the proper consistency is dependent on soil absorption and soil moisture. (Sections 3.3 through 3.3.4 describe the methods used to determine the following results.)

\subsubsection{Soil Moisture}

Table 4-1 contains soil moisture results.

Table 4-1. Soil Moisture Results

\begin{tabular}{|c|c|}
\hline Sample & Moisture Content (wt \%) \\
\hline $8-10 \mathrm{ft} \mathrm{bgs}$ & 9.1 \\
\hline $15-17 \mathrm{ft} \mathrm{bgs}$ & 4.0 \\
\hline $20-21 \mathrm{ft} \mathrm{bgs}$ & 4.1 \\
\hline $26-28 \mathrm{ft} \mathrm{bgs}$ & 3.3 \\
\hline Average moisture content & 5.1 \\
\hline
\end{tabular}




\subsubsection{Sieve Analysis}

Sieve analysis results are given in Table 4-2.

Table 4-2. Sieve Analysis Results

\begin{tabular}{|c|c|c|c|c|c|}
\hline $\begin{array}{c}\text { Sieve } \\
\text { Number }\end{array}$ & $\begin{array}{c}\text { Diameter } \\
\text { (mm) }\end{array}$ & $\begin{array}{c}\text { Run 1 } \\
\text { (\% finer) }\end{array}$ & $\begin{array}{c}\text { Run 2 } \\
\text { (\% finer) }\end{array}$ & $\begin{array}{c}\text { Run 3 } \\
\text { (\% finer) }\end{array}$ & $\begin{array}{c}\text { Average } \\
\text { (\% finer) }\end{array}$ \\
\hline 4 & 4.75 & 62.1 & 60.6 & 61.6 & 61.4 \\
\hline 10 & 2.00 & 39.7 & 39.8 & 39.3 & 39.6 \\
\hline 40 & 0.425 & 20.6 & 21.3 & 20.8 & 20.9 \\
\hline 100 & 0.150 & 9.7 & 9.9 & 9.5 & 9.7 \\
\hline 200 & 0.075 & 3.0 & 3.2 & 2.9 & 3.0 \\
\hline
\end{tabular}

\subsubsection{Soil Absorption}

Soil absorption was calculated by the equation:

$$
\text { Absorption } \%=[(\mathrm{S}-\mathrm{A}) / \mathrm{A}] \times 100 \%
$$

where

$$
\begin{aligned}
& S=\text { wet soil weight and } \\
& A=\text { oven-dry soil weight. }
\end{aligned}
$$

Table 4-3 shows the results of the calculations.

Table 4-3. Soil Absorption Results

\begin{tabular}{|c|c|}
\hline Soil Type & Absorption (\%) \\
\hline Composite & 9.4 \\
\hline+100 & 7.1 \\
\hline-100 & 22.6 \\
\hline
\end{tabular}




\subsubsection{Loose Bulk Density}

The loose bulk density of the soil was $93.6 \mathrm{lb} / \mathrm{ft}^{3}$.

\subsection{Reduction Experiments}

A satisfactory reducing agent was determined by employing 17 batch experiments (described in Section 3.6). Ferrous sulfate and ferrous ammonium sulfate provided sufficiently rapid kinetics, whereas $\mathrm{Fe}(0)$, blast furnace slag, and ferrous sulfide did not. Tables 4-4 through 4-7 show the experimental conditions and results of the batch experiments.

In the reduction experiments, the percent reduction was calculated by subtracting the concentration given by EPA Method 7196A (colorimetric analysis) from the initial concentration, then dividing this number by the initial concentration.

The addition of FS and FAS to the chromium solutions produced a floc that would precipitate from solution. Figures 4-1 and 4-2 show the results of the addition of these reducing agents in reduction experiments 12 and 13. The two samples shown on the far right in Figure 4-1 are from reduction experiment 12. All the samples shown in Figure 4-2 are from reduction experiment 13. 
Table 4-4. Reduction Experiments Using Fe(0), Blast Furnace Slag, or Steel Wool

\begin{tabular}{|c|c|c|c|c|c|}
\hline $\begin{array}{c}\text { Experiment } \\
\text { Number }\end{array}$ & $\begin{array}{c}\text { Reducing } \\
\text { Agent }^{a}\end{array}$ & pH Values $^{b}$ & $\begin{array}{l}\operatorname{Cr}(V I)^{c} \\
(m g / I)\end{array}$ & $\begin{array}{c}\text { Molar Ratio: } \\
\text { Reducing Agent/Cr(VI) }\end{array}$ & Results \\
\hline 1 & Fe powder & $\begin{array}{l}1.7,5.4,7.5, \text { and } \\
10.1\end{array}$ & 50 & 5 & $\begin{array}{l}100 \% \text { reduction in } \mathrm{pH} 1.7 \text { sample } \\
\text { immediately; others not reduced } \\
\text { after } 33 \text { days }\end{array}$ \\
\hline 2 & Fe powder & $2.0,2.5$, and 3.7 & 50 & 5 & $\begin{array}{l}100 \% \text { reduction in } \mathrm{pH} 2.0 \text { sample } \\
\text { immediately; others not reduced } \\
\text { after } 27 \text { days }\end{array}$ \\
\hline 3 & BFS & $\begin{array}{l}8.1,9.0,9.8, \text { and } \\
10.5\end{array}$ & 50 & N/A $: 7.0$ grams & No reduction after 27 days \\
\hline 4 & Fe powder & 7.5 & $10,20,30$, and 40 & 10 & No reduction after 23 days \\
\hline 5 & BFS & Neutral & $5,10,15$, and 20 & N/A: 2.0 grams & No reduction after 23 days \\
\hline 6 & Steel wool & 7.5 & $5,10,15$, and 20 & N/A: 0.75 grams & No reduction after 19 days \\
\hline 7 & Steel wool & $8.0,8.7,9.6,9.9$ & 10 & N/A: 0.7 grams & No reduction after 19 days \\
\hline
\end{tabular}

${ }^{\mathrm{a}} \mathrm{Fe}=$ iron; $\mathrm{BFS}=$ blast furnace slag.

${ }^{b}$ Neutral $=$ The $\mathrm{pH}$ of the solution was not measured and was near the $\mathrm{pH}$ of the tap water and DI water. The $\mathrm{pH}$ of the tap water and the DI water was approximately 8.

${ }^{c} \mathrm{Cr}(\mathrm{VI})=$ Hexavalent chromium.

$\mathrm{N} / \mathrm{A}=$ not applicable. 
Table 4-5. Reduction Experiments Using Ferrous Sulfide

\begin{tabular}{|c|c|c|c|c|c|}
\hline $\begin{array}{l}\text { Experiment } \\
\text { Number }\end{array}$ & $\begin{array}{l}\text { Reducing } \\
\text { Agent }^{\mathrm{a}}\end{array}$ & pH Values ${ }^{\mathrm{b}}$ & $\begin{array}{l}\mathrm{Cr}(\mathrm{VI})^{\mathrm{c}} \\
(\mathrm{mg} / \mathrm{l})\end{array}$ & $\begin{array}{l}\text { Molar Ratio: } \\
\text { Reducing } \\
\text { Agent/Cr(VI) }\end{array}$ & Results \\
\hline 8 & $\mathrm{FeS}$ & Neutral & $\begin{array}{l}\text { 1. } 20 \\
\text { 2. } 15 \\
\text { 3. } 10 \\
\text { 4. } 5\end{array}$ & $\begin{array}{l}\text { 1. } 542 \\
\text { 2. } 1084 \\
\text { 3. } 1626 \\
\text { 4. } 2168\end{array}$ & $\begin{array}{l}\text { Samples No. } 3 \text { and No. } 4 \\
\text { reduced in } 1 \text { day; Samples } \\
\text { No. } 1 \text { and No. } 2 \text { not reduced }\end{array}$ \\
\hline 9 & $\mathrm{FeS}$ & $\begin{array}{l}7.7,8.0,9.0 \text {, } \\
\text { and } 9.5\end{array}$ & 10 & 237 & $\begin{array}{l}\text { Samples analyzed after } 3 \text { days: } \\
\text { pH } 8.0 \text { and } 9.0 \text { samples } \\
\text { reduced, pH } 7.7 \text { sample reduced } \\
26 \% \text {, and } \mathrm{pH} 9.5 \text { sample } \\
\text { reduced } 52 \%\end{array}$ \\
\hline 10 & $\mathrm{FeS}$ & $\begin{array}{l}6.9,7.6,8.9 \\
\text { and } 9.3\end{array}$ & 10 & 237 & $\begin{array}{l}\text { Samples analyzed after } 1 \text { day: } \\
\text { pH } 6.9 \text { sample reduced, pH } 7.6 \\
\text { sample reduced } 91 \% \text {, pH } 8.9 \\
\text { sample reduced } 71 \% \text {, and pH } \\
9.3 \text { sample reduced } 53 \%\end{array}$ \\
\hline \multirow[t]{4}{*}{11} & FeS & 5.8 & 10 & 708 & Reduced in 28 hours \\
\hline & $\mathrm{FeS}$ & 5.3 & 20 & 354 & Reduced in 28 hours \\
\hline & FeS & 5.1 & 30 & 236 & Reduced in 28 hours \\
\hline & $\mathrm{FeS}$ & 5.1 & 40 & 177 & Reduced in 28 hours \\
\hline \multirow[t]{2}{*}{12} & FeS & $7.9,8.9$ & 100 & 100 & No reduction after 6 days \\
\hline & $\mathrm{FeS}$ & $7.9,8.9$ & 100 & 200 & No reduction after 6 days \\
\hline
\end{tabular}

${ }^{\mathrm{a}} \mathrm{FeS}=$ Ferrous sulfide.

${ }^{b}$ Neutral $=$ The $\mathrm{pH}$ of the solution was not measured and was near the $\mathrm{pH}$ of the tap water and DI water. The $\mathrm{pH}$ of the tap water and the DI water was approximately 8.

${ }^{\mathrm{c}} \mathrm{Cr}(\mathrm{VI})=$ Hexavalent chromium . 
Table 4-6. Reduction Experiments Using Ferrous Sulfate or Ferrous Ammonium Sulfate

\begin{tabular}{|c|c|c|c|c|c|}
\hline $\begin{array}{c}\text { Experiment } \\
\text { Number }\end{array}$ & $\begin{array}{c}\text { Reducing } \\
\text { Agent }^{\mathrm{a}}\end{array}$ & pH Values & $\begin{array}{l}\operatorname{Cr}(\mathrm{VI})^{\mathrm{b}} \\
(\mathrm{mg} / \mathrm{l})\end{array}$ & $\begin{array}{l}\text { Molar Ratio: } \\
\text { Reducing } \\
\text { Agent/Cr(VI) }\end{array}$ & Results \\
\hline \multirow[t]{2}{*}{12} & FS & $7.9,8.9$ & 100 & 55 & Reduced immediately $^{c}$ \\
\hline & FAS & $7.9,8.9$ & 100 & 72 & Reduced immediately ${ }^{c}$ \\
\hline \multirow[t]{4}{*}{13} & FS & $\begin{array}{l}9.0,10.0,11.0, \\
\text { and } 11.4 \text { using } \\
\mathrm{NH}_{4} \mathrm{OH}\end{array}$ & 100 & 28 & $\begin{array}{l}\text { Samples reduced immediately, } \\
\text { except } \mathrm{pH} 11.4 \text { sample not } \\
\text { reduced }\end{array}$ \\
\hline & FS & $\begin{array}{l}9.9,11.0 \text { using } \\
\mathrm{NaOH}\end{array}$ & 100 & 28 & Reduced immediately \\
\hline & FAS & $\begin{array}{l}9.0,10.0,11.0 \\
\text { and } 11.4 \text { using } \\
\mathrm{NH}_{4} \mathrm{OH}\end{array}$ & 100 & 36 & Reduced immediately \\
\hline & FAS & $\begin{array}{l}9.9,11.0 \text { using } \\
\mathrm{NaOH}\end{array}$ & 100 & 36 & Reduced immediately \\
\hline \multirow[t]{2}{*}{14} & FS & $\begin{array}{l}8.0,9.0,10.0 \\
11.0, \text { and } 11.5\end{array}$ & 100 & 5.5 & Reduced immediately \\
\hline & FAS & $\begin{array}{l}8.0,9.0,10.0 \\
11.0, \text { and } 11.5\end{array}$ & 100 & 7.2 & Reduced immediately \\
\hline
\end{tabular}

${ }^{2} \mathrm{FS}=$ Ferrous sulfate; $\mathrm{FAS}=$ ferrous ammonium sulfate.

${ }^{\text {b }} \mathrm{Cr}(\mathrm{VI})=$ Hexavalent chromium.

Note: FS, pH changed to 3.9 ; FAS, pH changed to 3.6. 
Table 4-7. Reduction Experiments Using Ferrous Sulfate and Uncontaminated Soil

\begin{tabular}{|c|c|c|c|c|c|}
\hline $\begin{array}{l}\text { Experiment } \\
\text { Number }\end{array}$ & $\begin{array}{l}\text { Reducing } \\
\text { Agent }^{\mathrm{a}}\end{array}$ & pH Values ${ }^{b}$ & $\begin{array}{l}\mathrm{Cr}(\mathrm{VI})^{\mathrm{c}} \\
(\mathrm{mg} / \mathrm{l})\end{array}$ & $\begin{array}{l}\text { Molar Ratio: } \\
\text { Reducing } \\
\text { Agent/Cr(VI) }\end{array}$ & Results \\
\hline 15 & FS & 8.0 & 100 & $\begin{array}{l}\text { 1. } 1.1 \\
\text { 2. } 2.7 \\
\text { 3. } 5.5\end{array}$ & $\begin{array}{l}\text { Sample No. } 1 \text { not reduced, } \\
\text { Sample No. } 2 \text { reduced } 99.5 \% \text {, } \\
\text { and Sample No. } 3 \text { reduced }\end{array}$ \\
\hline 16 & FS & $\begin{array}{l}\text { Neutral and } \\
\text { added } 0.2 \mathrm{ml} \\
\mathrm{NaOH}\end{array}$ & 100 & $\begin{array}{ll}\text { 1. } & 1.1 \\
\text { 2. } & 1.6 \\
\text { 3. } & 2.2\end{array}$ & $\begin{array}{l}\text { Sample No. } 1 \text { not reduced, } \\
\text { Sample No. } 2 \text { reduced } 30 \% \text {, and } \\
\text { Sample No. } 3 \text { reduced } 64 \%\end{array}$ \\
\hline \multirow[t]{2}{*}{17} & FS & Neutral & 500 & $\begin{array}{l}\text { 1. } 2.2 \\
\text { 2. } 2.7 \\
\text { 3. } 4.4\end{array}$ & $\begin{array}{l}\text { Sample No. } 1 \text { reduced } 80 \% \text {, } \\
\text { Sample No. } 2 \text { reduce } 99 \% \text {, and } \\
\text { Sample No. } 3 \text { reduced }\end{array}$ \\
\hline & FS & Neutral & 1000 & $\begin{array}{l}\text { 1. } 2.2 \\
\text { 2. } 2.7 \\
\text { 3. } 4.4\end{array}$ & $\begin{array}{l}\text { Sample No. } 1 \text { reduced } 86 \% \text {, } \\
\text { Sample No. } 2 \text { reduce } 89 \% \text {, and } \\
\text { Sample No. } 3 \text { reduced }\end{array}$ \\
\hline
\end{tabular}

Note: Samples were turned on a daisy wheel for 24 hours prior to ferrous sulfate addition.

${ }^{2} \mathrm{FS}=$ Ferrous sulfate.

"Neutral $=$ The $\mathrm{pH}$ of the solution was not measured and was near the $\mathrm{pH}$ of the tap water and DI water. The $\mathrm{pH}$ of the tap water and the DI water was approximately 8 .

${ }^{\circ} \mathrm{Cr}(\mathrm{VI})=$ Hexavalent chromium. 


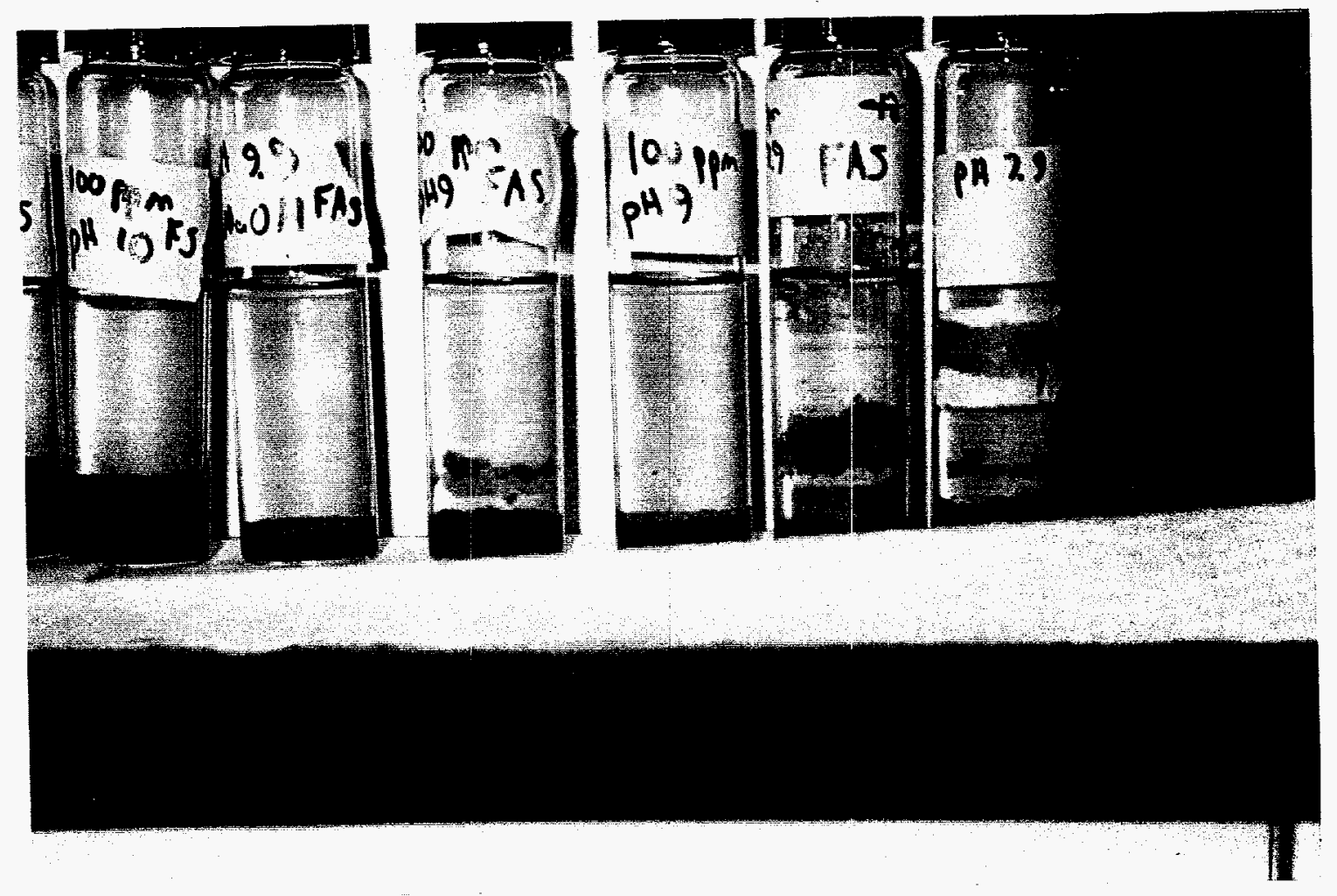

Figure 4-1. Floc Produced in Reduction Experiments 12 and 13

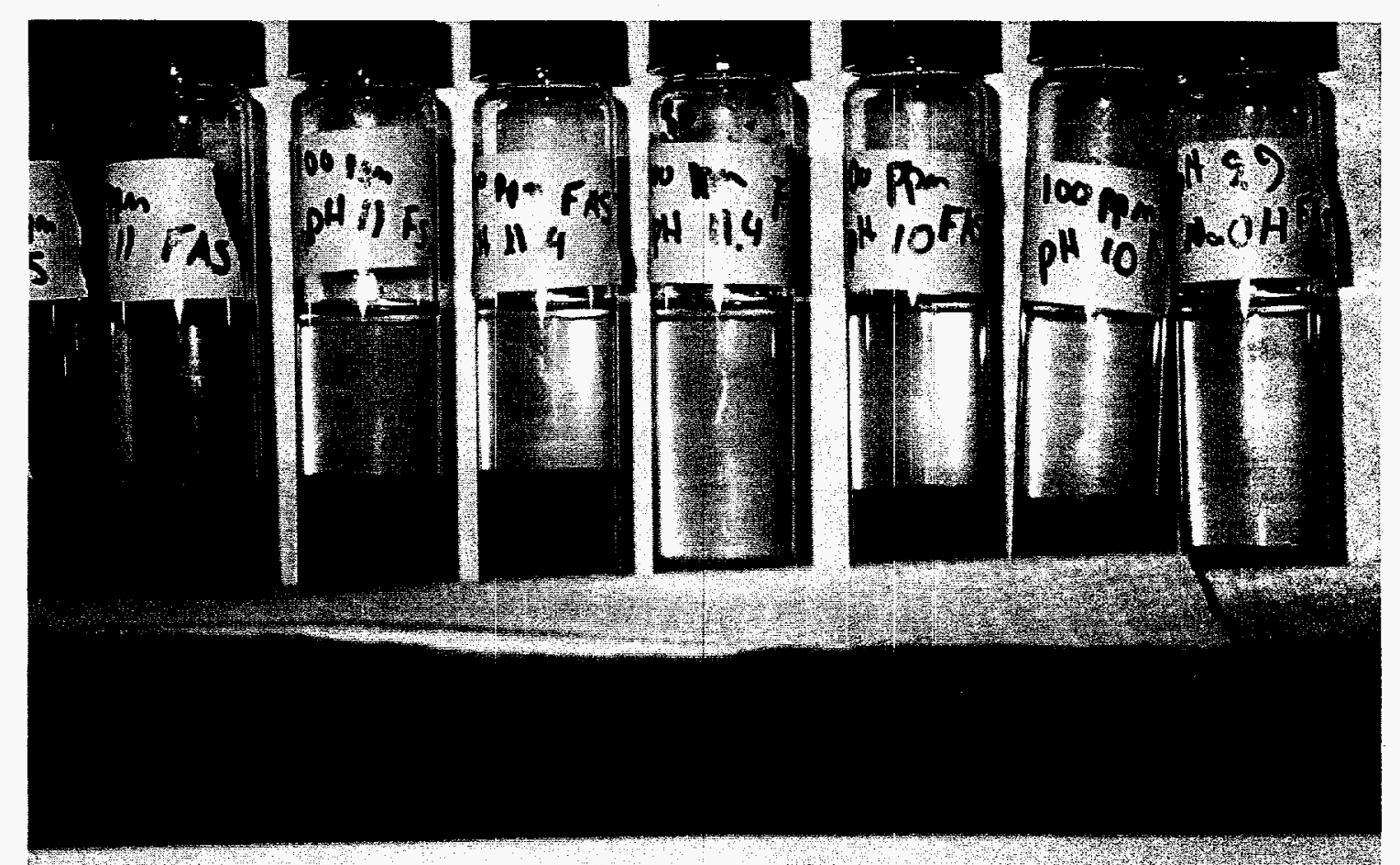

Figure 4-2. Floc Produced in Reduction Experiment 13 
A qualitative demonstration of the colorimetric analysis can be seen in Figures 4-3 and 4-4. Figure 4-3 shows reduction experiment 10 samples prepared for colorimetric analysis. The $\mathrm{pH} 6.9$ sample is clear, indicating that all $\mathrm{Cr}(\mathrm{VI})$ was reduced to $\mathrm{Cr}(\mathrm{III})$. From right to left, the other samples becomes darker in color, indicating less reduction to $\mathrm{Cr}$ (III). The data for these samples are contained in Table 4-5. Figure 4-4 shows reduction experiment 12 and 13 samples prepared for colorimetric analysis. All samples were reduced, except for the $\mathrm{pH} 11.4$ ferrous sulfate sample, as indicated by the red-violet color.

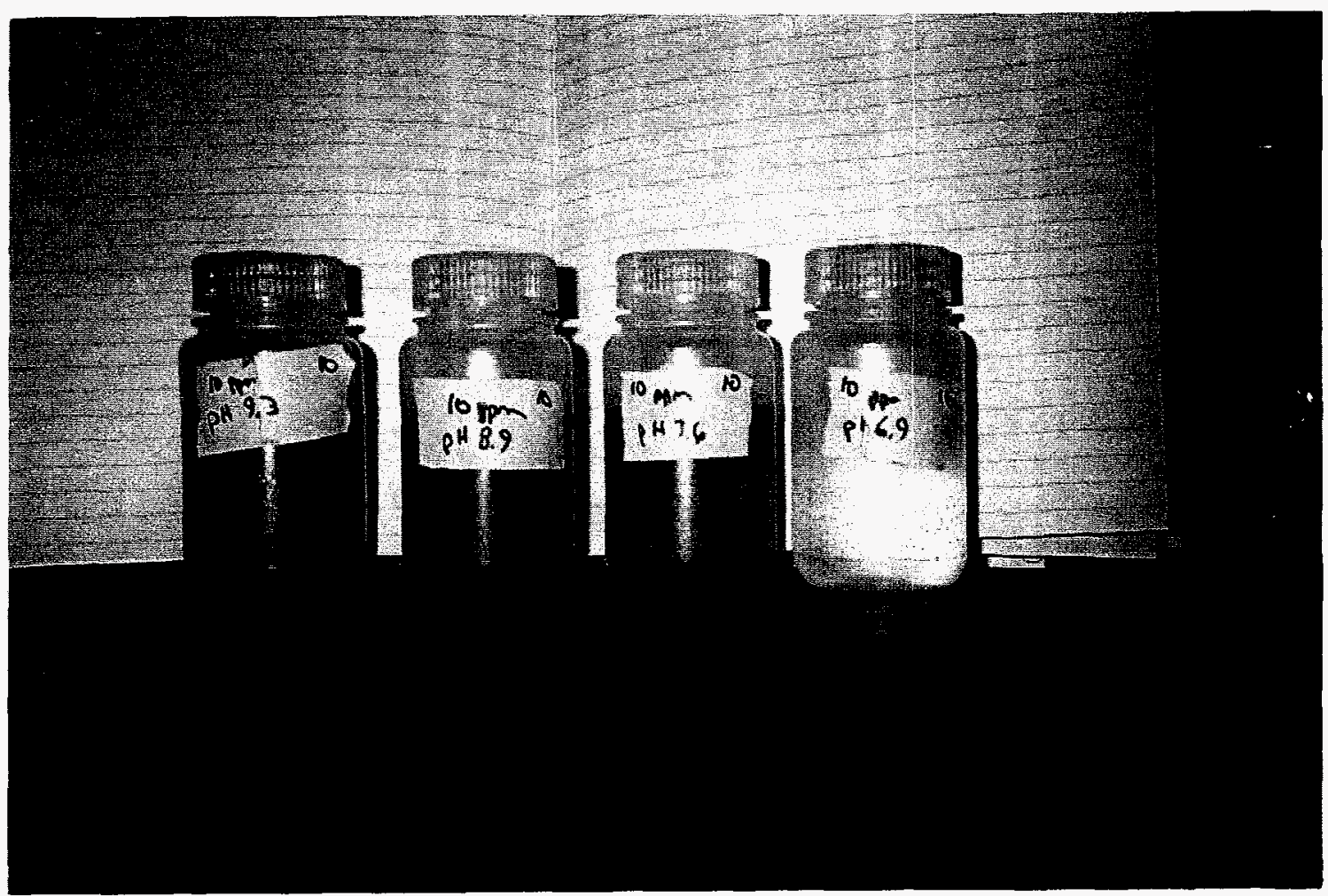

Figure 4-3. Reduction Experiment 10 Samples Prepared for Colorimetric Analysis 


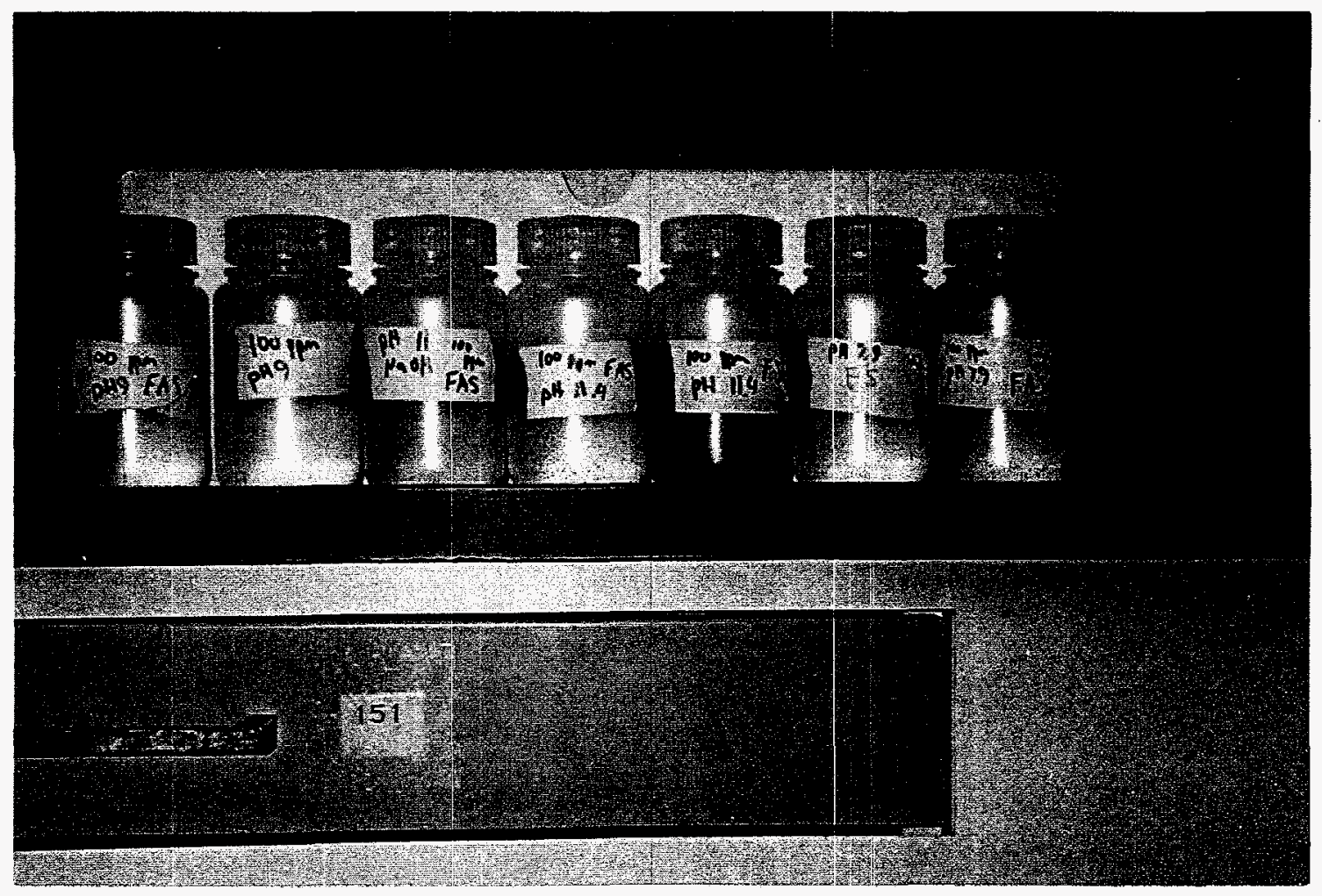

Figure 4-4. Reduction Experiments 12 and 13 Prepared for Colorimetric Analysis

\subsection{Soil Chemical Data}

The data presented in this section were essential for determining the amount of reducing agent required so that the treated waste would pass the TCLP. Sections 3.7 through 3.7.6 describe the chemical test methods used on the soil.

\subsubsection{Chromium Concentration and Speciation with Depth}

Before the soil was composited, the chromium oxidation state in the soil was determined below the disposal pit. Figure $4-5$ shows the results. 


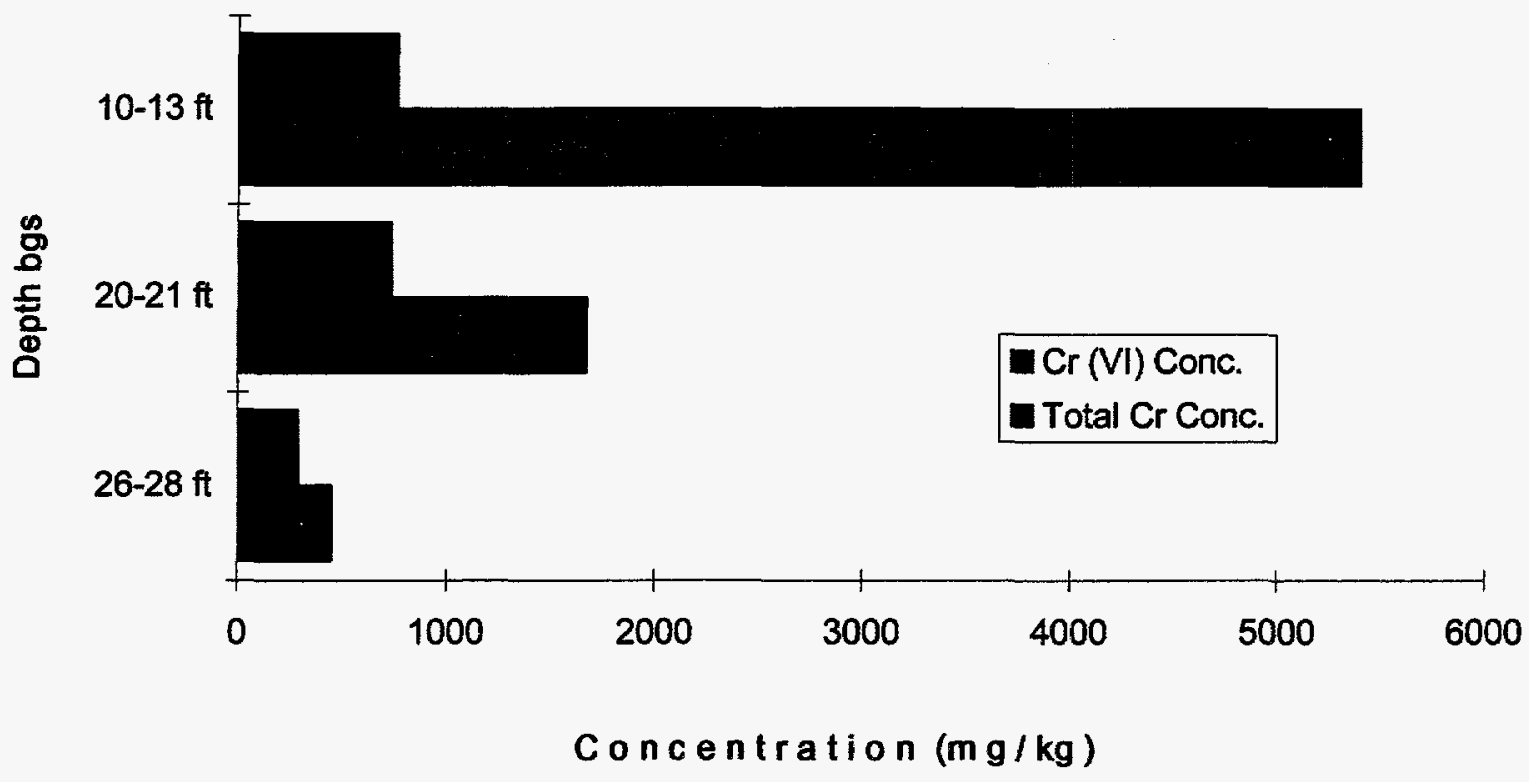

Figure 4-5. Chromium Oxidation State with Depth Below the Disposal Pit. The $\mathrm{Cr}(\mathrm{VI})$ concentrations were determined by a water leach experiment (described in Section 3.6, 48-hour data).

\subsubsection{Chromium Concentration and Speciation in the Three Soil Classifications}

After the soil was composited, the total chromium and $\mathrm{Cr}(\mathrm{VI})$ concentrations were determined in the three soil classifications. Figure 4-6 presents the data.

\subsubsection{Toxicity Characteristic Leaching Procedure}

The three soil classifications were subjected to the TCLP to determine whether the material was a RCRA-regulated waste. Table 4-8 shows the TCLP results. 


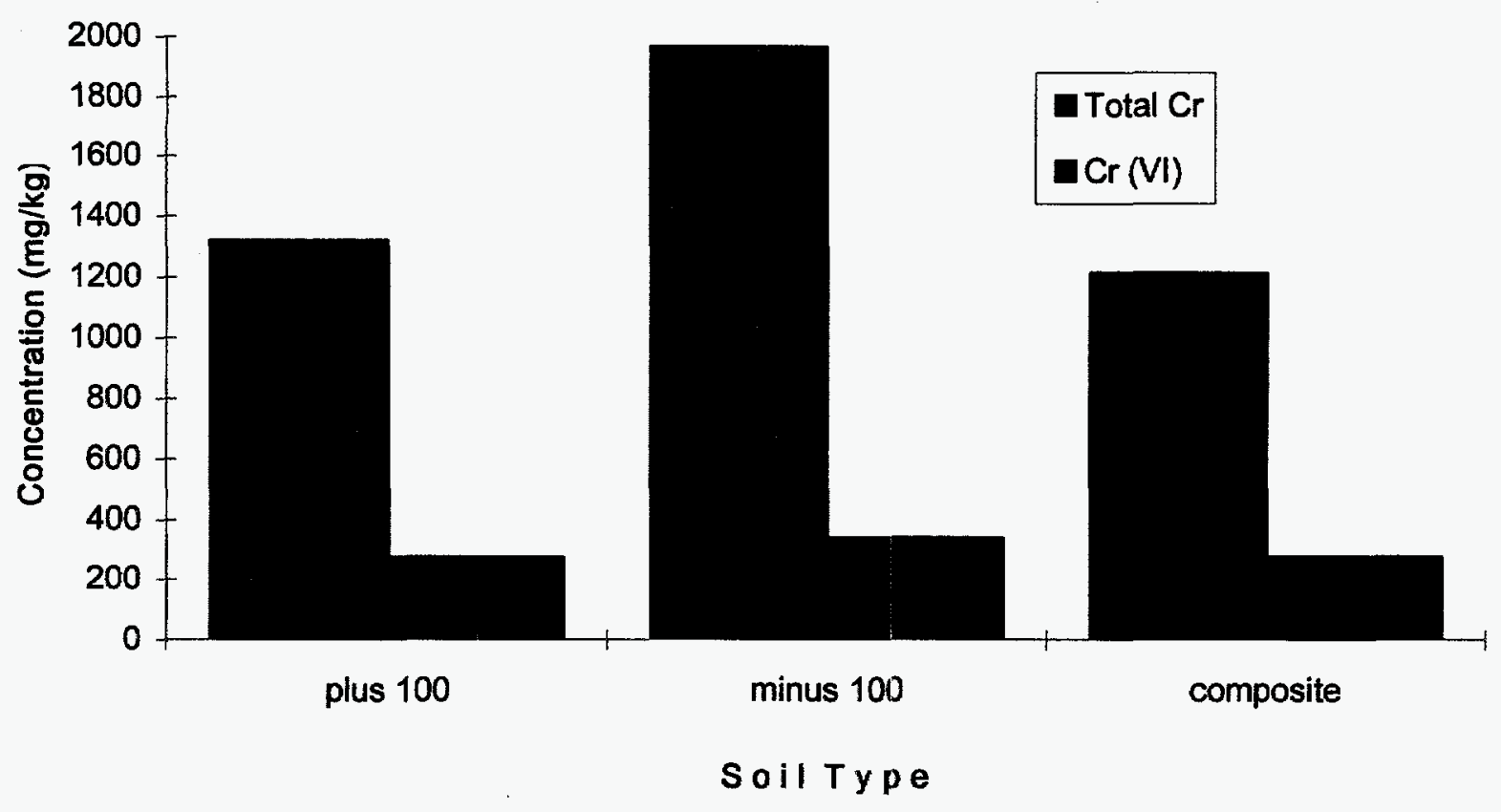

Figure 4-6. Chromium Oxidation State in the Three Soil Classifications

Table 4-8. Results of the Toxicity Characteristic Leaching Procedure for the Three Soil Classifications

\begin{tabular}{|c|c|c|}
\hline Soil Type & UNM $^{\mathrm{a}}$ Results $(\mathbf{m g} / \mathbf{l})$ & GEL $^{\mathbf{b}}$ Results $(\mathbf{m g} / \mathbf{l})$ \\
\hline+100 & 8.0 & 7.96 \\
\hline Composite & 8.1 & 10.6 \\
\hline-100 & 15.0 & 12.8 \\
\hline
\end{tabular}

${ }^{2} \mathrm{UNM}=$ University of New Mexico (UNM results were determined by the author). ${ }^{\mathrm{b}} \mathrm{GEL}=$ General Engineering Laboratories.

GEL performed the TCLP for all RCRA metals. The values obtained for the other RCRA metals are significantly below regulatory levels or not detected. 


\subsubsection{Sulfate Concentration}

Table 4-9 shows the sulfate concentration determined for the three soil classifications.

Table 4-9. Sulfate Concentration

\begin{tabular}{|c|c|}
\hline Soil Type & $\begin{array}{c}\text { Sulfate Concentration in Soil } \\
(\mathbf{m g} / \mathbf{k g})\end{array}$ \\
\hline+100 & 11,520 \\
\hline Composite & 8,590 \\
\hline-100 & 15,530 \\
\hline
\end{tabular}

\subsection{5 pH Values}

The soil $\mathrm{pH}$ value, 8.1 , was the same for the three soil classifications.

\subsection{Mortar Mixer Experiments}

A crucial set of experiments were performed to determine whether the reduction reaction kinetics would be fast enough in the mortar mixing bowl. The first experiment used $23 \mathrm{lb}(10.4 \mathrm{~kg})$ of composite soil and $79.0 \mathrm{~g}$ of ferrous sulfate. Most of the chromium in the first batch was reduced, resulting in a Cr(VI) concentration of $0.1 \mathrm{mg} / \mathrm{l}$ in the free water.

The second experiment used $10 \mathrm{lb}(4.5 \mathrm{~kg})$ of composite soil and no ferrous sulfate. The chromium in the second batch was not reduced, resulting in a $\mathrm{Cr}(\mathrm{VI})$ concentration greater than $10 \mathrm{mg} / \mathrm{l}$ in the free water. The colorimetric procedure is only valid for $\mathrm{Cr}(\mathrm{VI})$ concentrations at or below $10 \mathrm{mg} / \mathrm{l}$; therefore, concentrations greater than $10 \mathrm{mg} / 1$ could not be determined.

The third experiment used the same soil-water mix as the second batch. In this experiment, $33.0 \mathrm{~g}$ of ferrous sulfate were added. The chromium was reduced, resulting in a Cr(VI) concentration of less than $0.1 \mathrm{mg} / \mathrm{l}$ in the free water. Another $33.0 \mathrm{~g}$ of ferrous sulfate was added, with no further reduction in the Cr(VD).

The fourth experiment used $10 \mathrm{lb}(4.5 \mathrm{~kg})$ of composite soil and $29.2 \mathrm{~g}$ of ferrous sulfate. The chromium was reduced, resulting in a $\mathrm{Cr}(\mathrm{VI})$ concentration of less than $0.1 \mathrm{mg} / \mathrm{l}$ in the free water. 


\subsection{Uncontaminated Soil Concrete Data}

With successful chromium reduction in the mortar mixer, the first set of soil concrete batches using contaminated soil could be made. Before presenting the data for the set of contaminated-soil concrete batches, it is important to see the compressive strength results of the uncontaminated soil concrete. Figure 4-7 presents the uncontaminated-soil concrete strength data. The following graphs (Figures 4-7 through 4-10, 4-14, and 4-18) present the average values for the compressive strength data.

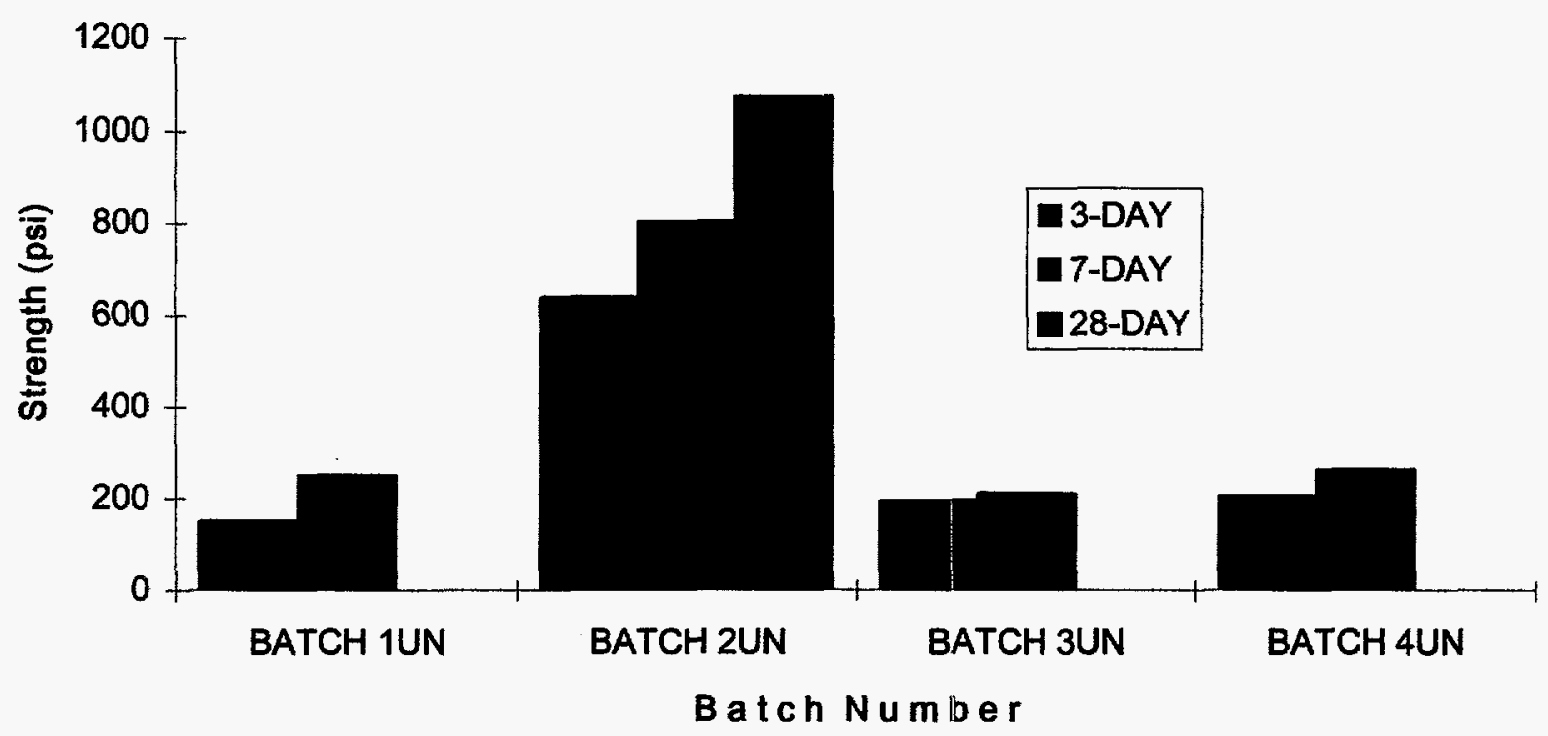

Figure 4-7. Compressive Strength of Uncontaminated Soil Concrete

Batch 2UN had the only reportable data for 28 days. Batch $1 \mathrm{UN}$ samples were not tested because they could not meet the required parallelism without extensive work. Batches $3 \mathrm{UN}$ and 4UN were not tested at 28 days due to 3 - and 7-day strength data and batch $2 \mathrm{UN}$ strength data, which led to a preliminary conclusion that the desired strength was bracketed by these initial cement concentrations.

\subsection{Second Optimization Step: Batches 1 through 11}

Batches 1 through 11 are the initial set of contaminated soil batches; batches 8 through 11 are repeats of batches $1,2,3$, and 6 , except more water was added to make them pourable, but not self-leveling. Figures 4-8 through 4-10 present the compressive strength of batches 1 through 7, batches 8 through 11, and batch couples (same mix except more water), respectively. 


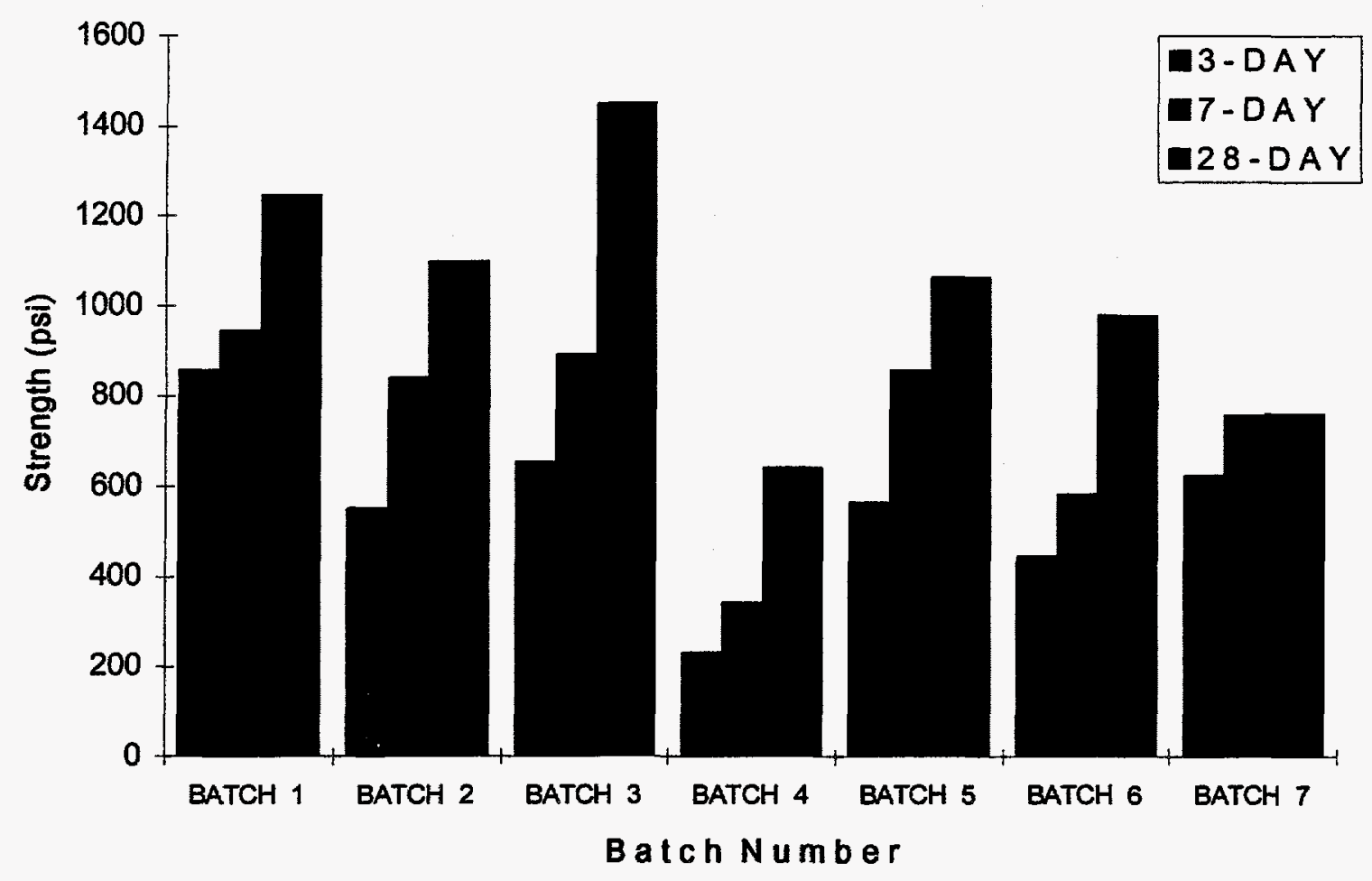

Figure 4-8. Compressive Strength of Batches 1 through 7

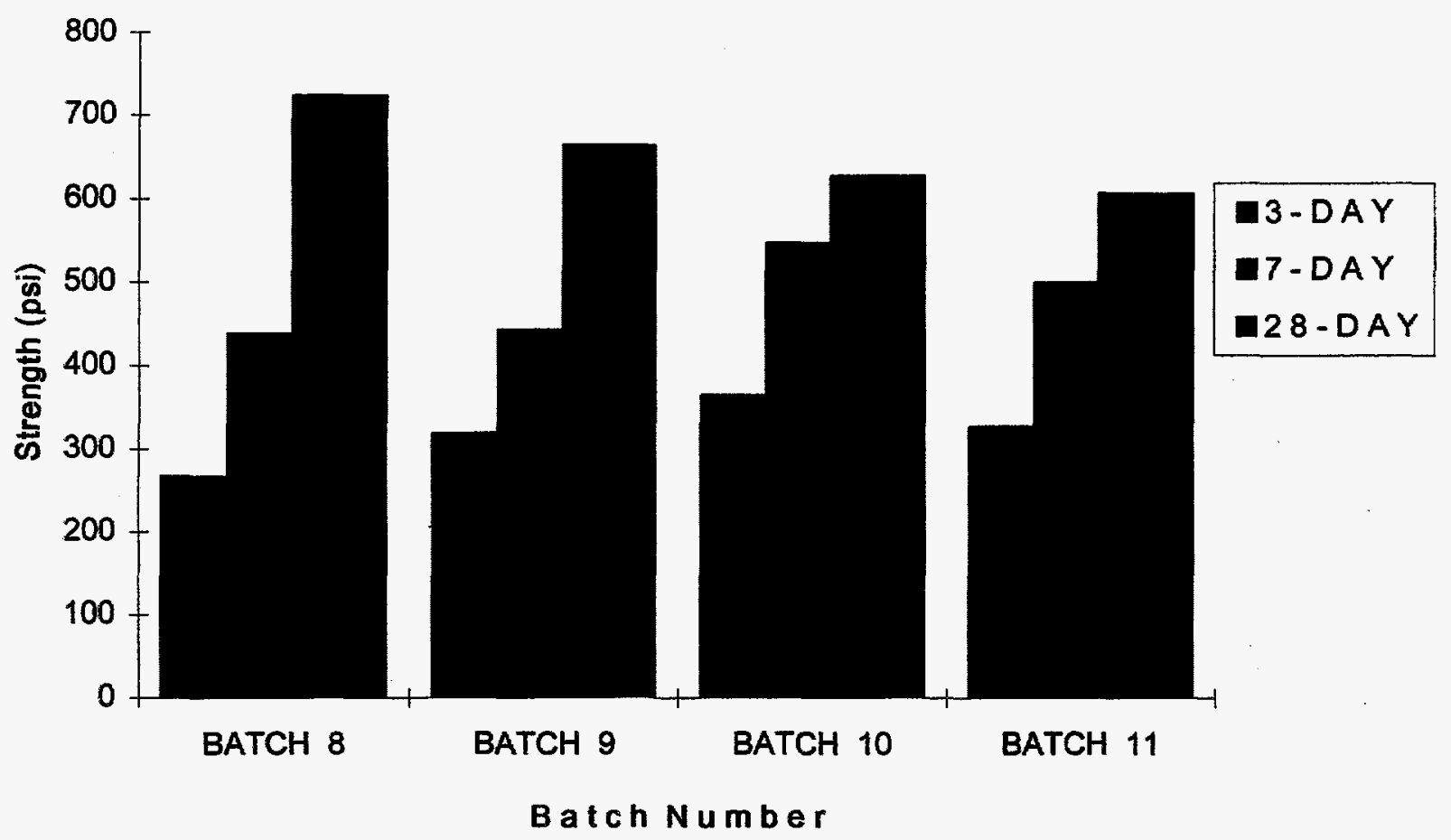

Figure 4-9. Compressive Strength of Batches 8 through 11 


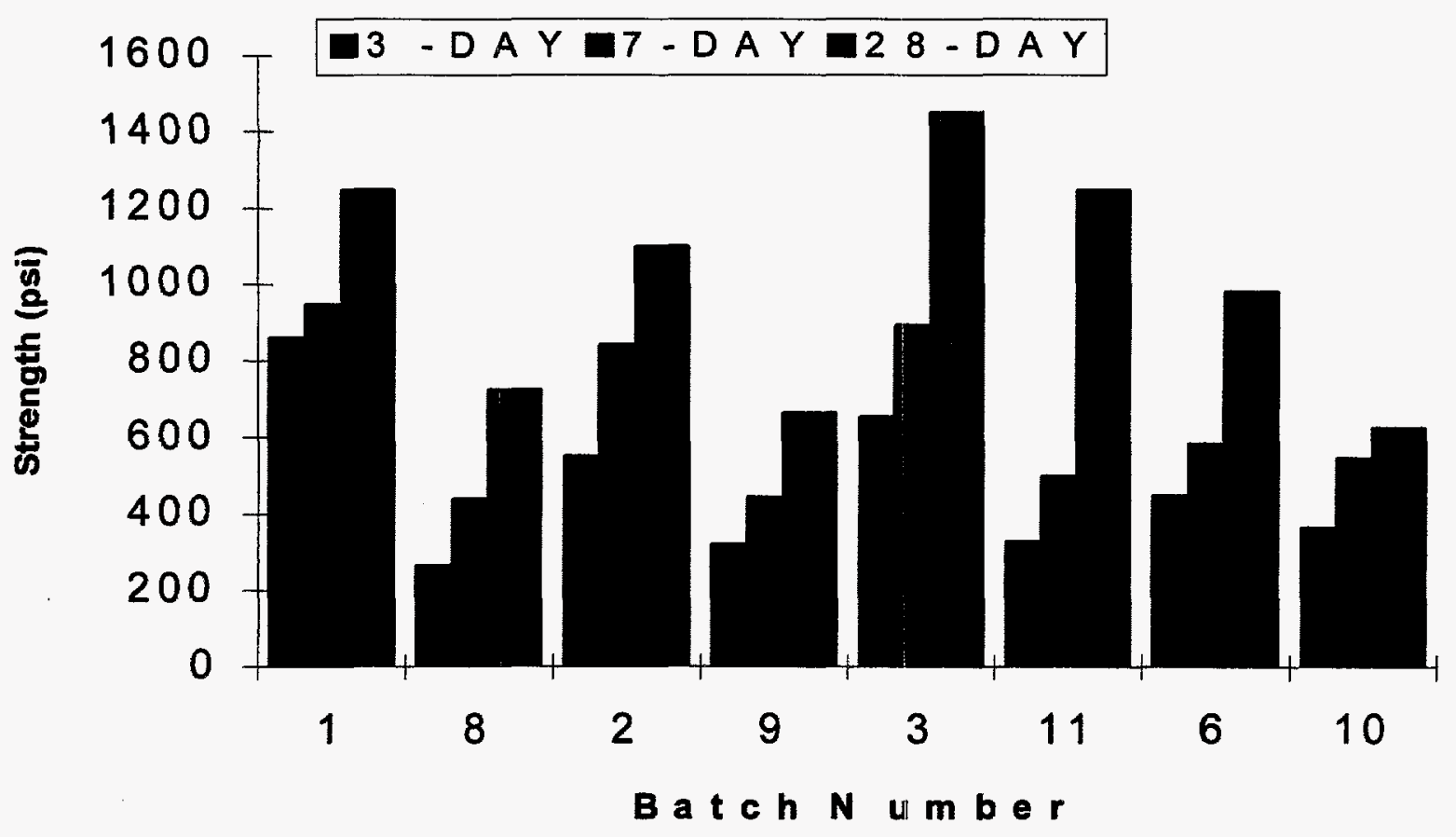

Figure 4-10. Compressive Strength of Batch Couples. The batch couples are batches 1 and 8 , batches 2 and 9, batches 3 and 11 , and batches 6 and 10 .

Following unconfined compressive testing, samples were subjected to the TCLP. TCLP samples were cured for 3 and 28 days. Figures 4-11 through 4-13 present the TCLP data for batches 1 through 7, batches 8 through 11, and the batch couples, respectively.

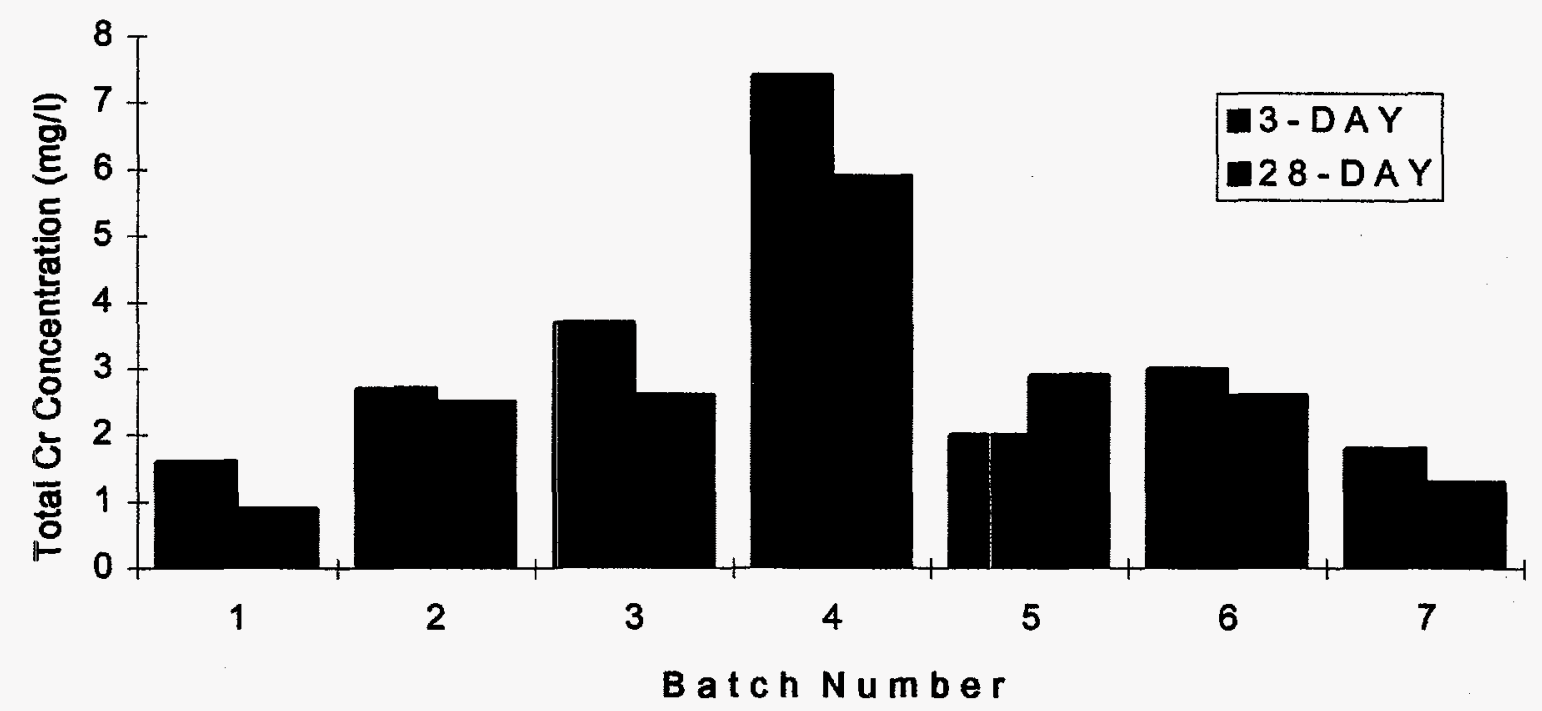

Figure 4-11. Experiment Results for Extract Concentrations Using the Toxicity Characteristic Leaching Procedure, Batches 1 through 7 


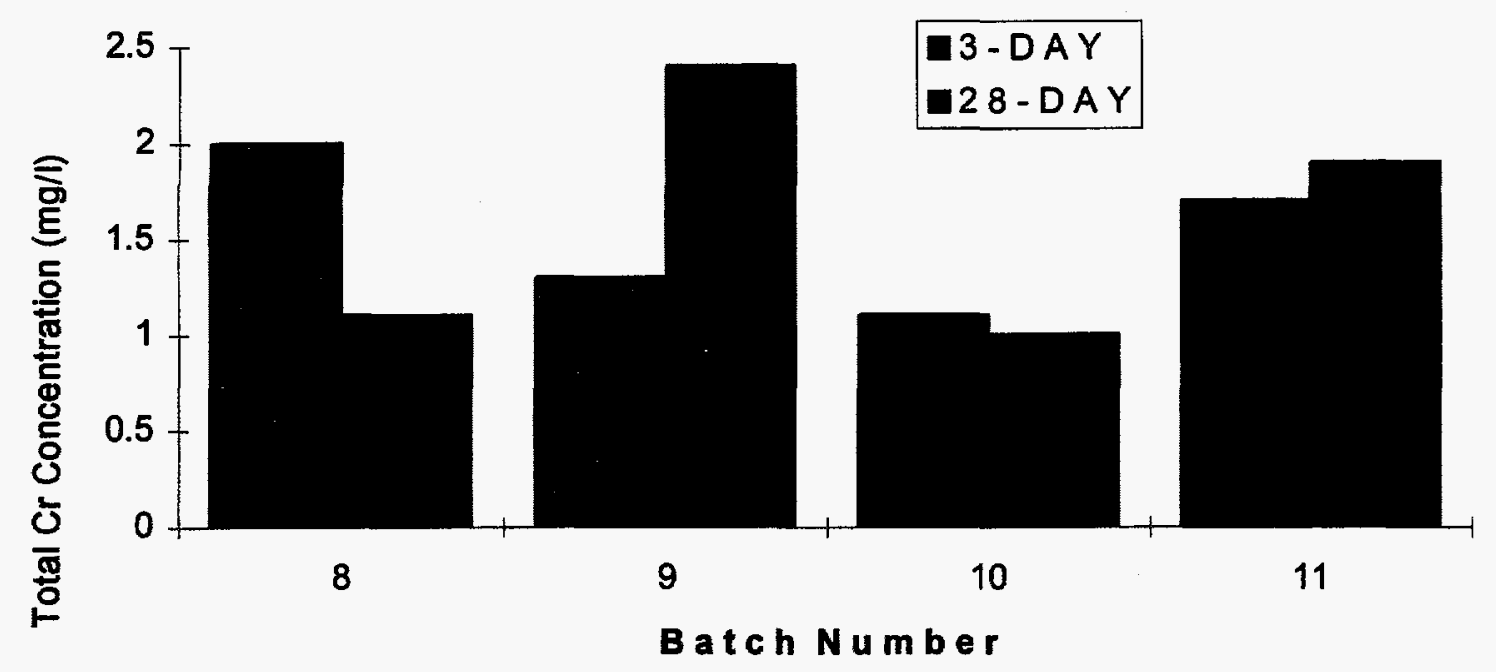

Figure 4-12. Experiment Results for Extract Concentrations Using the Toxicity Characteristic Leaching Procedure, Batches 8 through 11

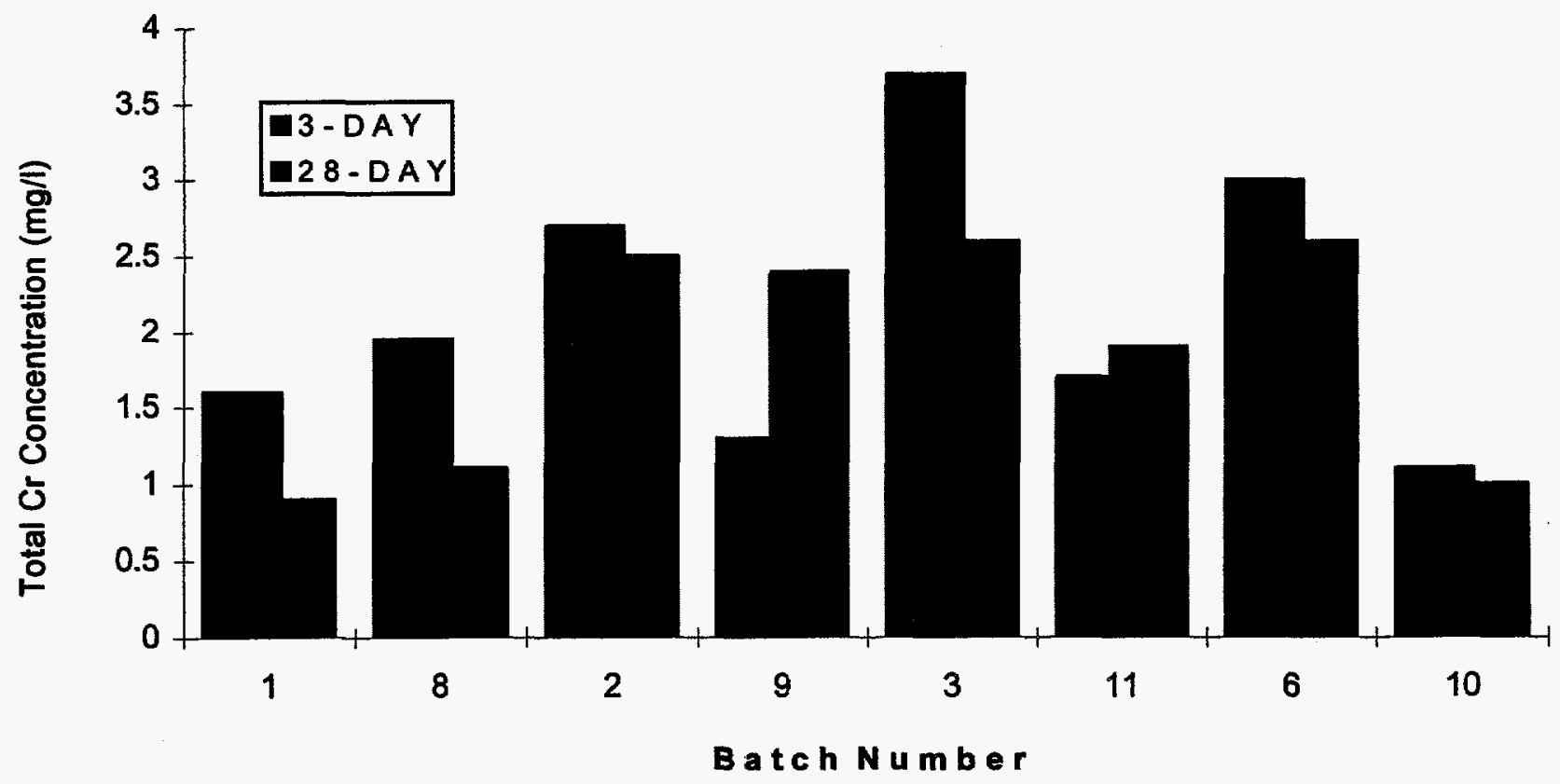

Figure 4-13. Experiment Results for Extract Concentrations Using the Toxicity Characteristic Leaching Procedure, Batch Couples 


\subsection{Third Optimization Step: Batches 12 through 17}

Batches 12 through 17 were prepared based on results from the previous optimization step. Figure 4-14 presents the unconfined compressive strength data. The 3day strength for batch 15 was near zero, therefore, it does not appear on Figure 4-14.

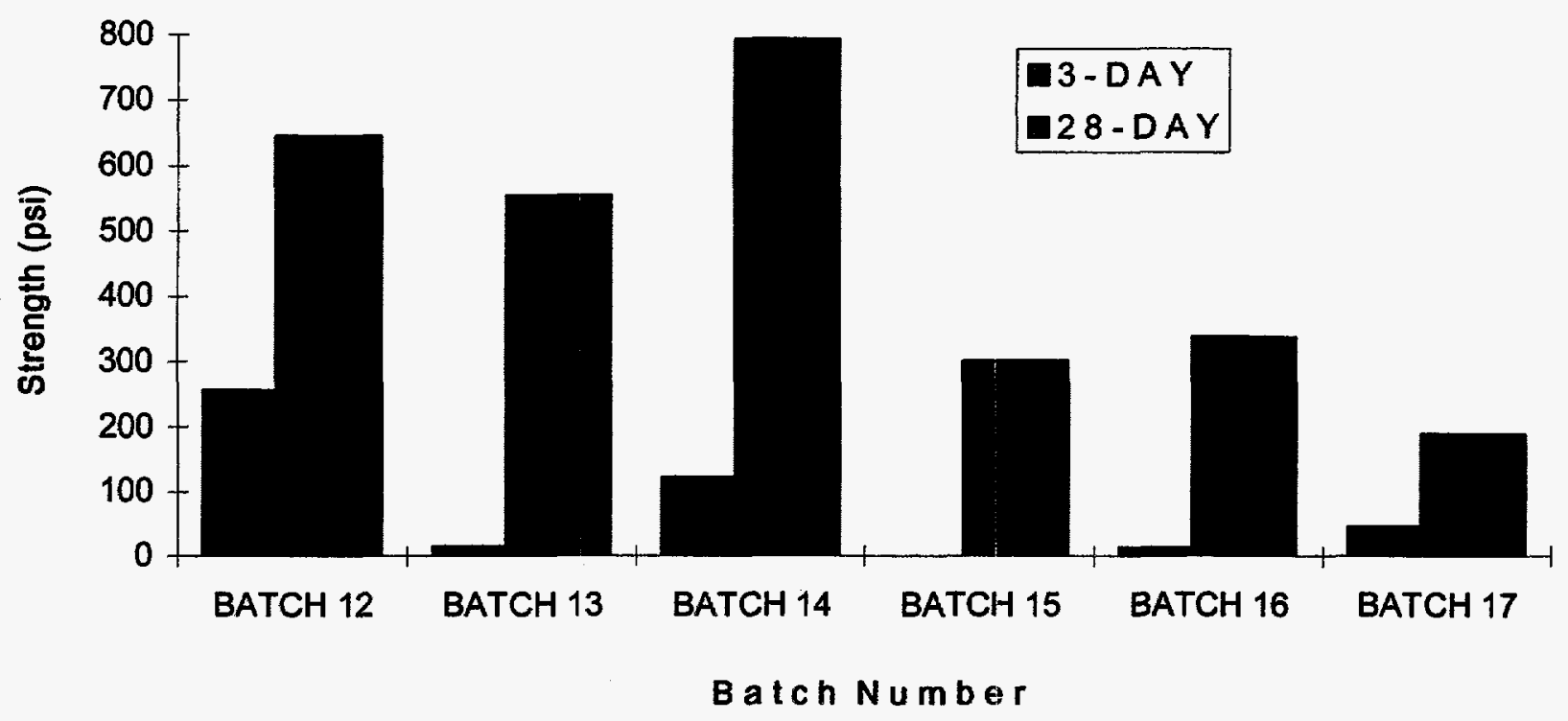

Figure 4-14. Compressive Strength of Batches 12 through 17

Following strength testing, samples were subjected to the TCLP. Figures 4-15 through 4-17 present the TCLP data of batches 12 through 17, cured 3 days; batches 12 through 17, cured 28 days; and batches 13 through 16, cured 28 days, respectively. Each column represents an individual sample. 


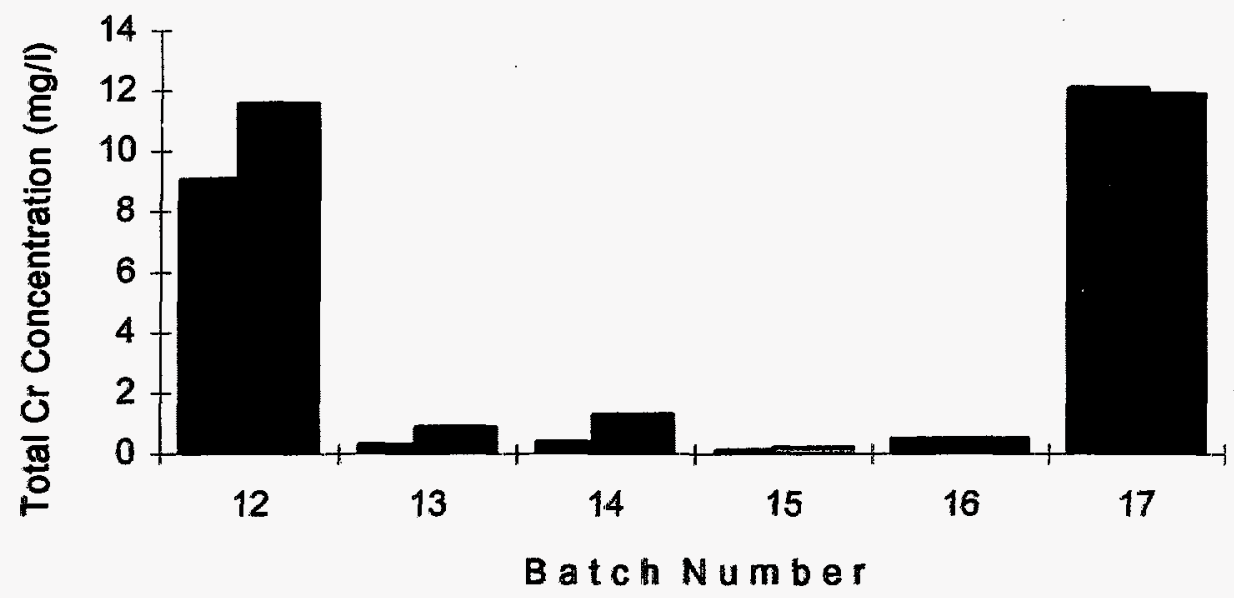

Figure 4-15. Experiment Results for Extract Concentrations Using the Toxicity Characteristic Leaching Procedure, Batches 12 through 17. Samples were cured 3 days.

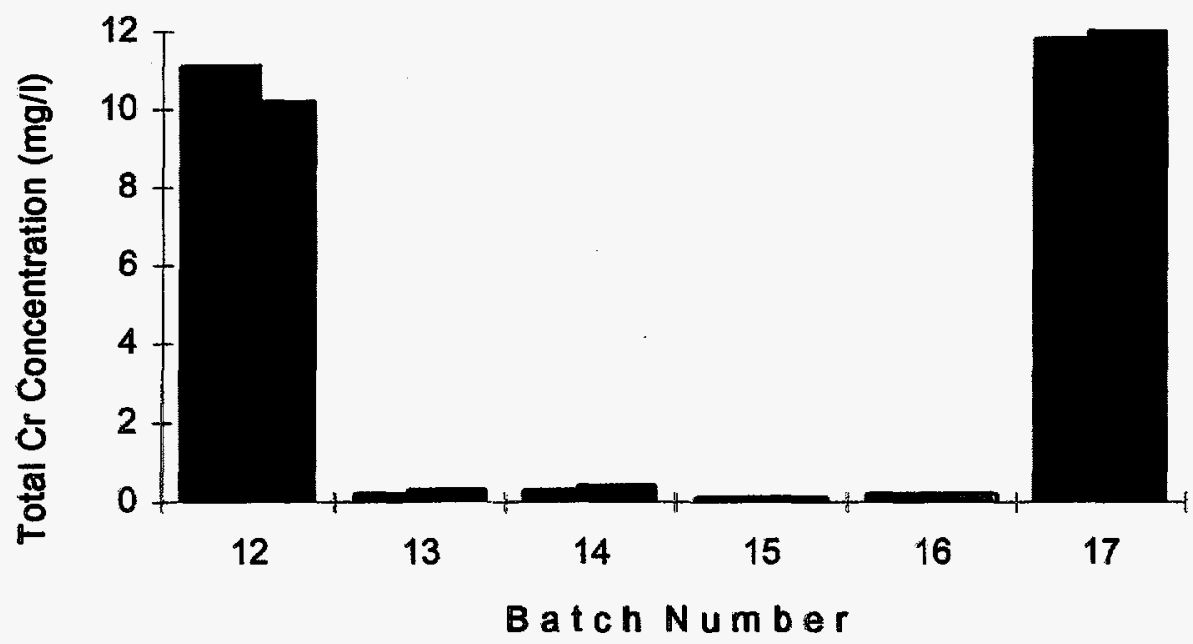

Figure 4-16. Experiment Results for Extract Concentrations Using the Toxicity Characteristic Leaching Procedure, Batches 12 through 17. Samples were cured 28 days. 


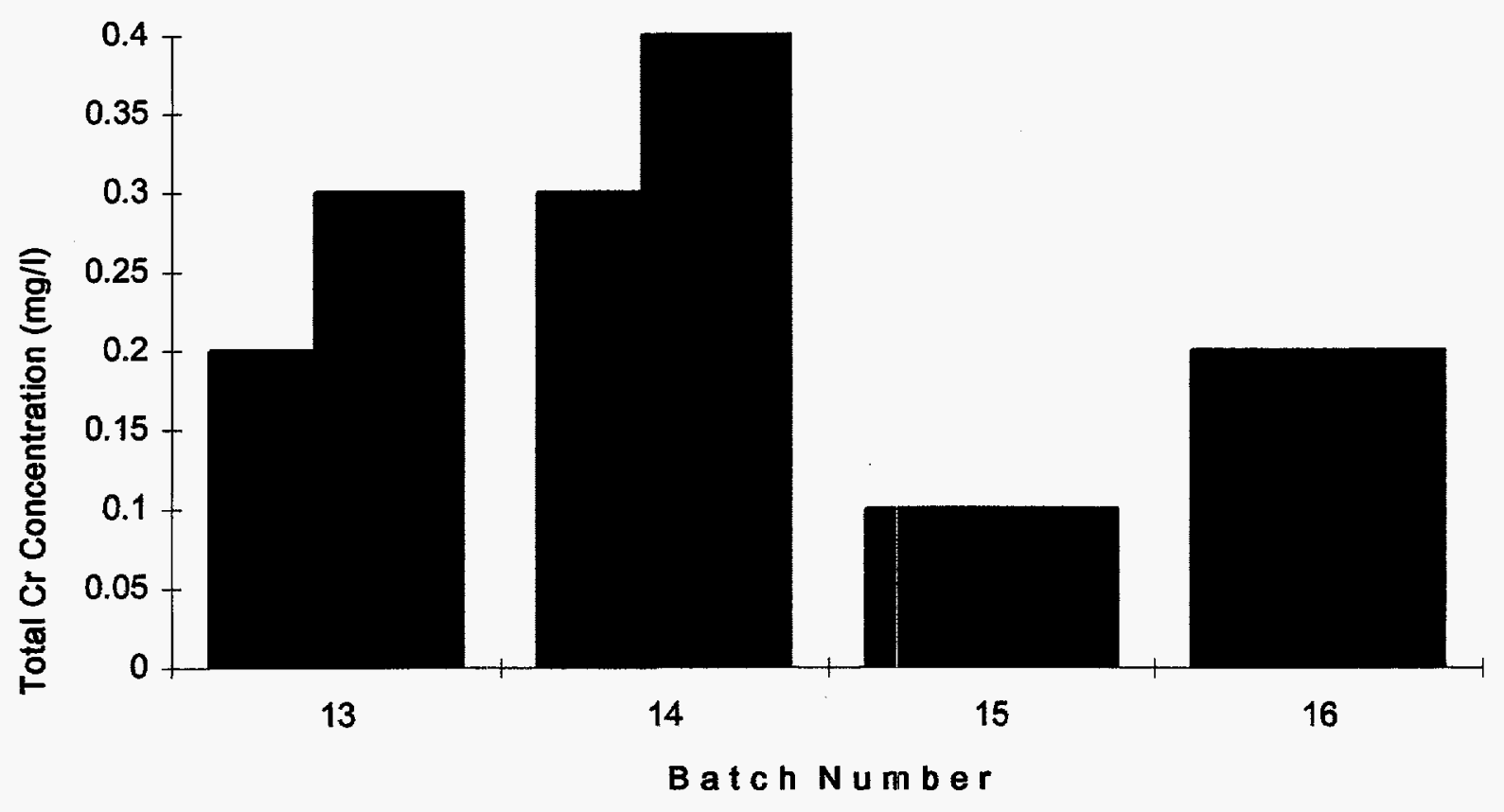

Figure 4-17. Experiment Results for Extract Concentrations Using the Toxicity Characteristic Leaching Procedure, Batches 13 through 16. Samples were cured 28 days.

\subsection{Confirmation Step: Batches 18, 19, and 20}

Batches 18,19 , and 20 were prepared based on results from the previous optimization step. Figure 4-18 shows the compressive strength of batches 18, 19, and 20 . The 3-day strength for batch 19 was near zero, therefore, it does not appear on Figure 418. Batch 20 was only tested at 28 days, due to the limited amount of material. 


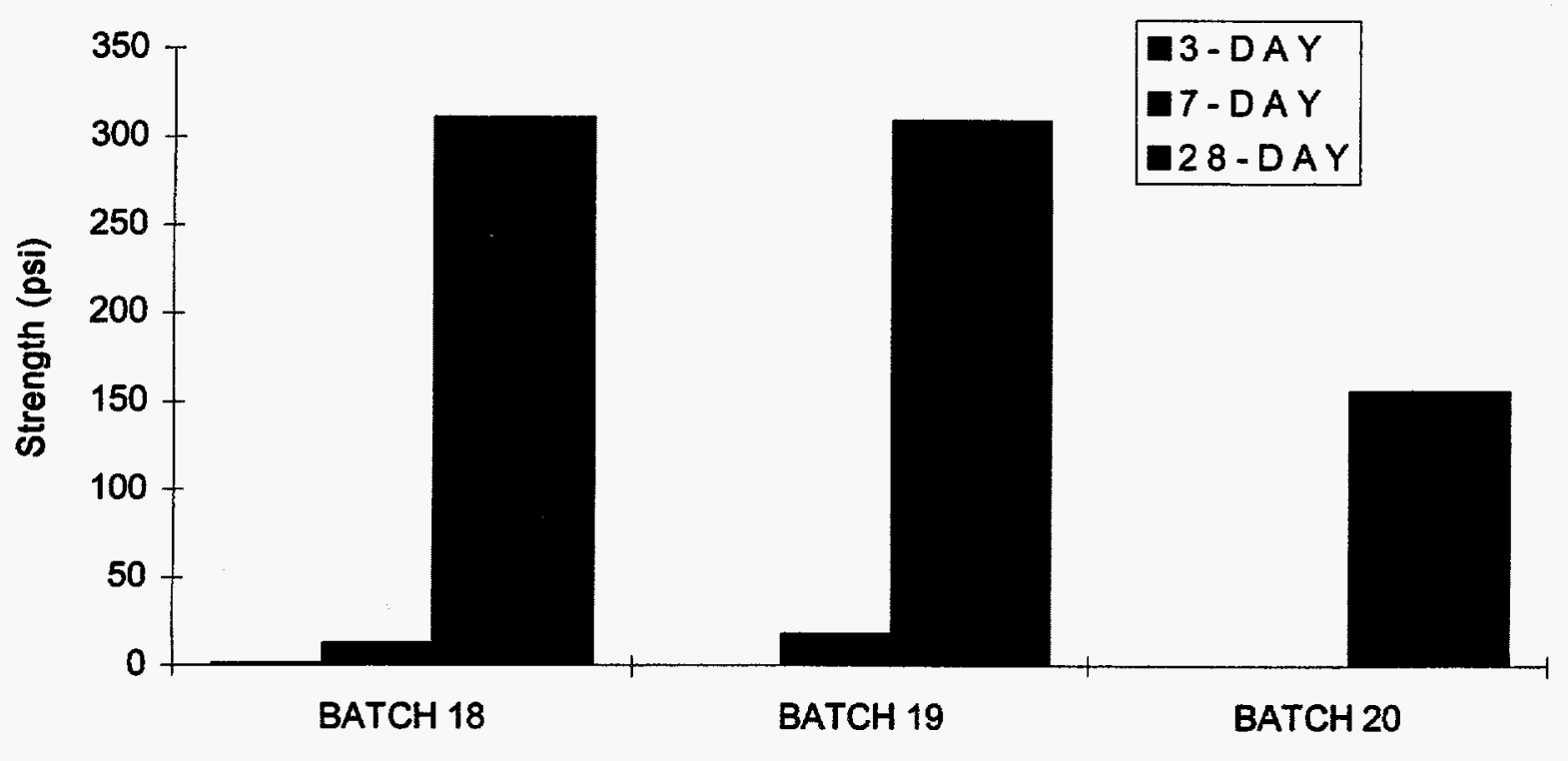

Batch Number

Figure 4-18. Compressive Strength of Batches 18, 19, and 20 
After the samples were compression tested, they were subjected to the TCLP. Figures 4-19 and 4-20 present the TCLP data for batches 18, 19, and 20.

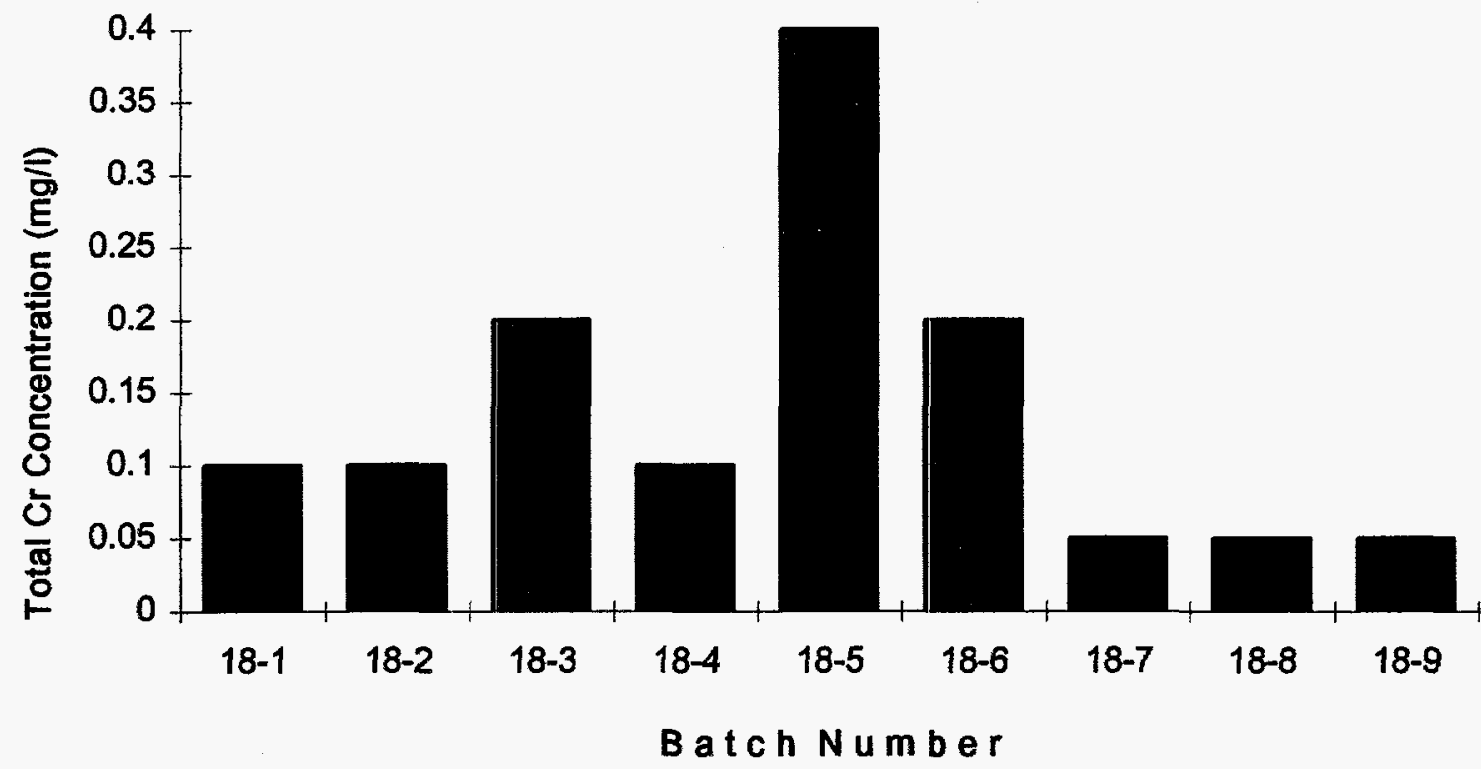

Figure 4-19. Experiment Results for Extract Concentrations Using the Toxicity Characteristic Leaching Procedure, Batch 18

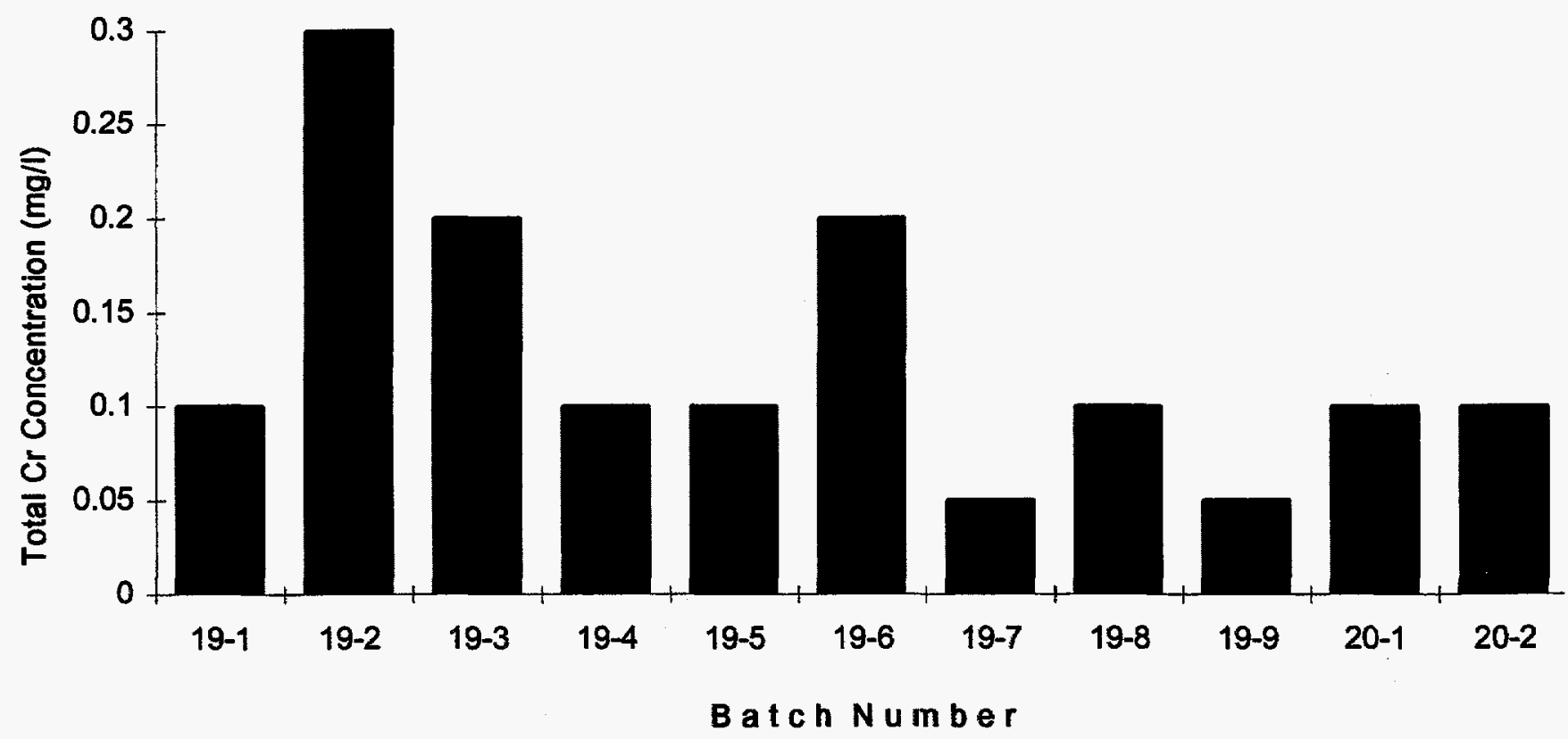

Figure 4-20. Experiment Results for Extract Concentrations Using the Toxicity Characteristic Leaching Procedure, Batches 19 and 20 


\subsection{Results of the Toxicity Characteristic Leaching Procedure for the Soil Concrete}

Table 4-10 presents a comparison of the TCLP results for two different laboratories.

Table 4-10. Results of the Toxicity Characteristic Leaching Procedure for the Soil Concrete

\begin{tabular}{|c|c|c|}
\hline Sample & UNM $^{\mathrm{a}}$ Results $(\mathbf{m g} / \mathbf{l})$ & GEL $^{\mathrm{b}}$ Results $(\mathbf{m g} / \mathbf{l})$ \\
\hline $18-4$ & 0.1 & 0.844 \\
\hline $19-4$ & 0.1 & 0.701 \\
\hline
\end{tabular}

${ }^{a}$ UNM = University of New Mexico (UNM results were determined by the author).

${ }^{\mathrm{b}} \mathrm{GEL}=$ General Engineering Laboratories.

\subsection{Chromium Oxidation State in the Extract from the Toxicity Characteristic Leaching Procedure}

TCLP leachates were analyzed in accordance with EPA Method 7196 to determine the oxidation state of the chromium. The chromium in the TCLP leachate was in the $\mathrm{Cr}(\mathrm{VI})$ oxidation state. The data have not been presented herein because they nearly duplicate the data already presented.

\subsection{Soil Concrete Bulk Density}

The bulk density of selected samples was determined before compressive strength testing. Table 4-11 presents the data. (Section 3.12 describes the method used for determining the bulk density.) 
Table 4-11. Bulk Density of Selected Soil Concrete Samples

\begin{tabular}{|c|c|}
\hline Sample & Bulk Density $\left(\mathrm{lb} / \mathrm{ft}^{3}\right)$ \\
\hline $18-7$ & 128 \\
\hline $18-8$ & 129 \\
\hline $19-7$ & 126 \\
\hline $19-8$ & 126 \\
\hline $19-9$ & 126 \\
\hline $20-1$ & 111 \\
\hline $\begin{array}{l}\text { Note: Samples 18-9 and 20-2 were not used in the determination } \\
\text { of bulk density due to the cylinders missing material. }\end{array}$ \\
\hline
\end{tabular}

\subsection{Soil Concrete Sulfate Concentration}

The sulfate concentration in the TCLP extract was $720 \mathrm{mg} / 1$. The effects of elevated sulfate concentrations are discussed in Section 5.9.

\subsection{Reduced Data}

All data presented graphically in this section are provided in the reduced form in Appendix B.

\subsection{Photographs of Soil Concrete}

Figures 4-21 through 4-27 are photographs of the soil concrete cured for 28 days unless otherwise specified. 


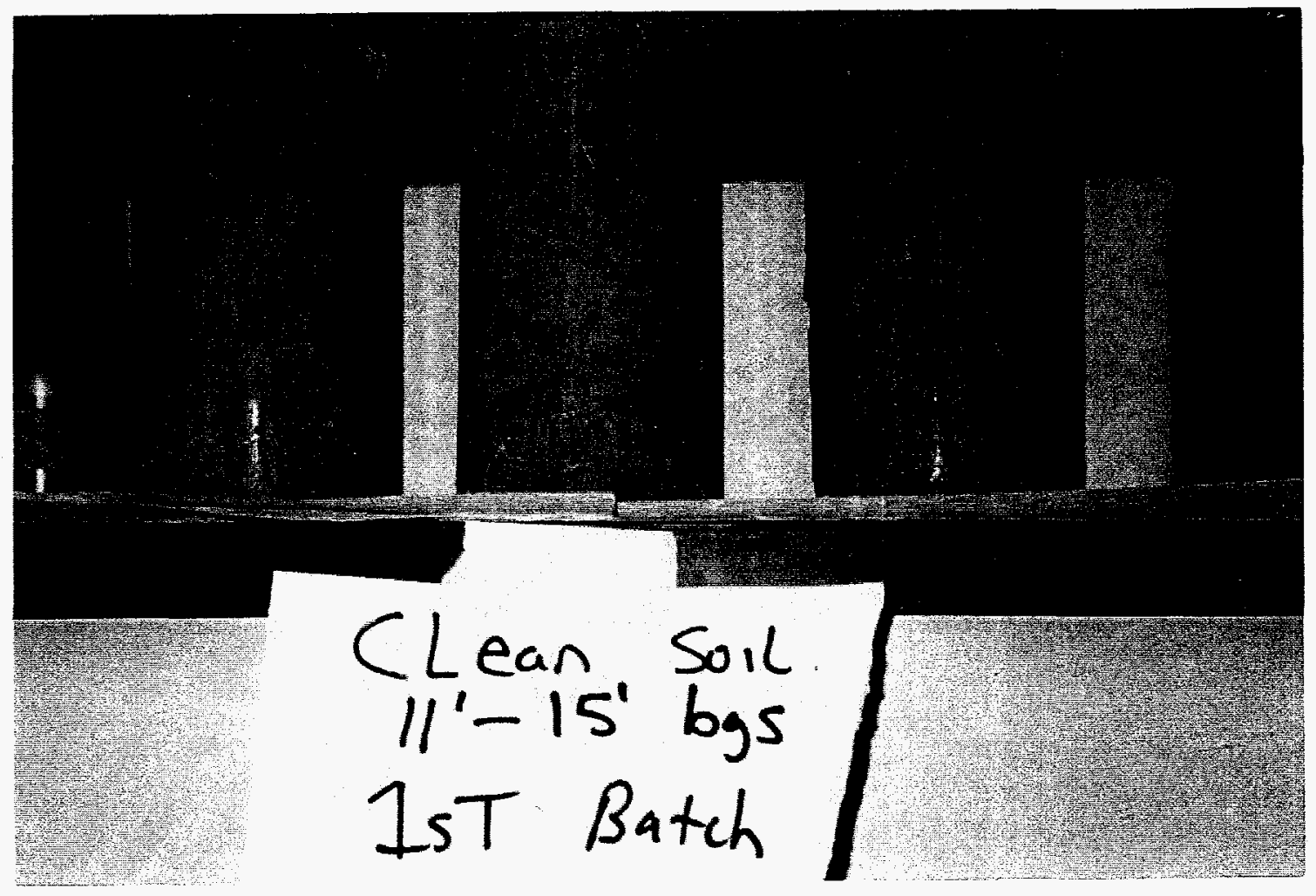

Figure 4-21. Photograph of Soil Concrete Using Uncontaminated Soil 

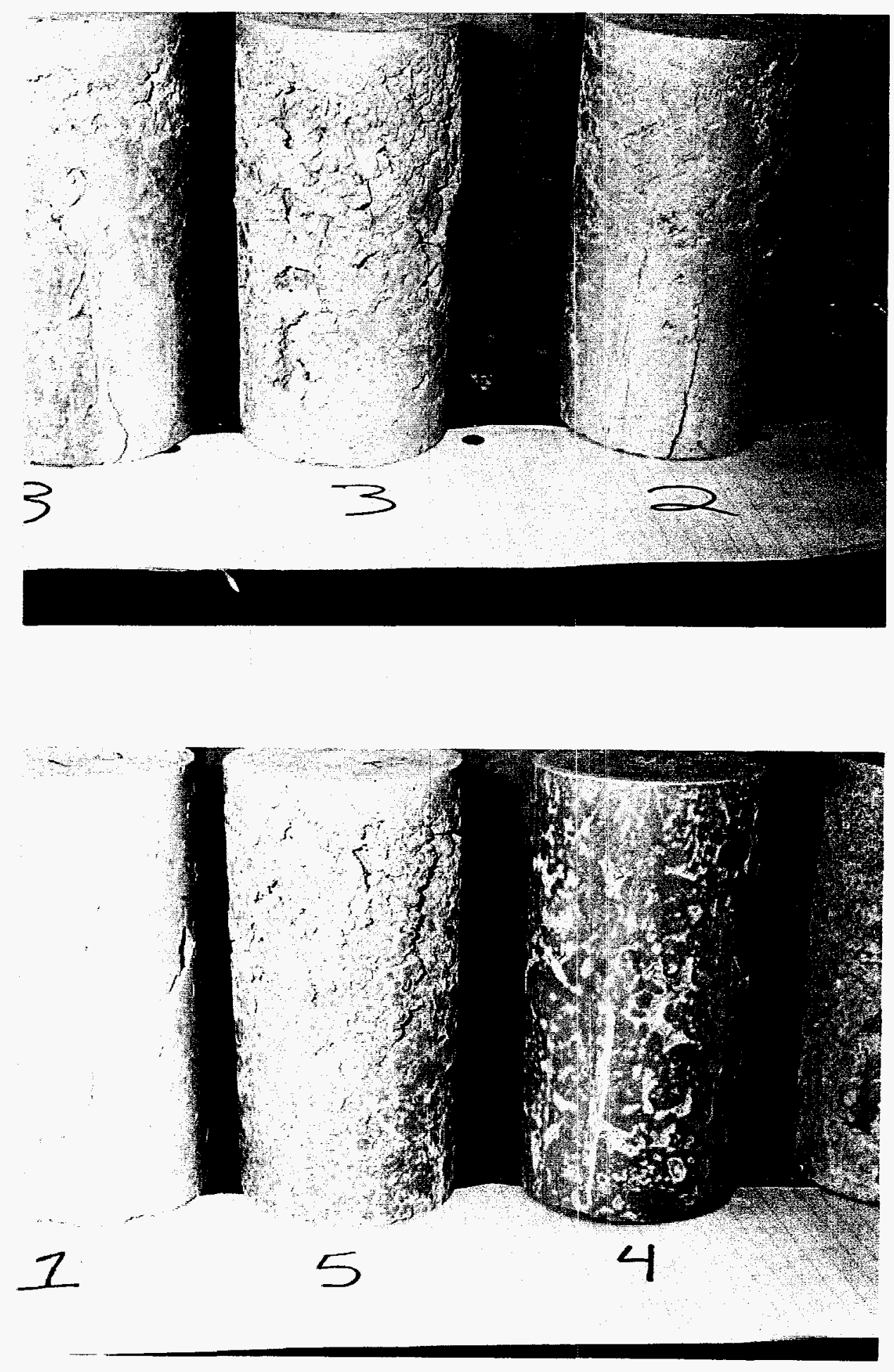

Figure 4-22. Photographs of Batches 1 through 5 Soil Concrete 


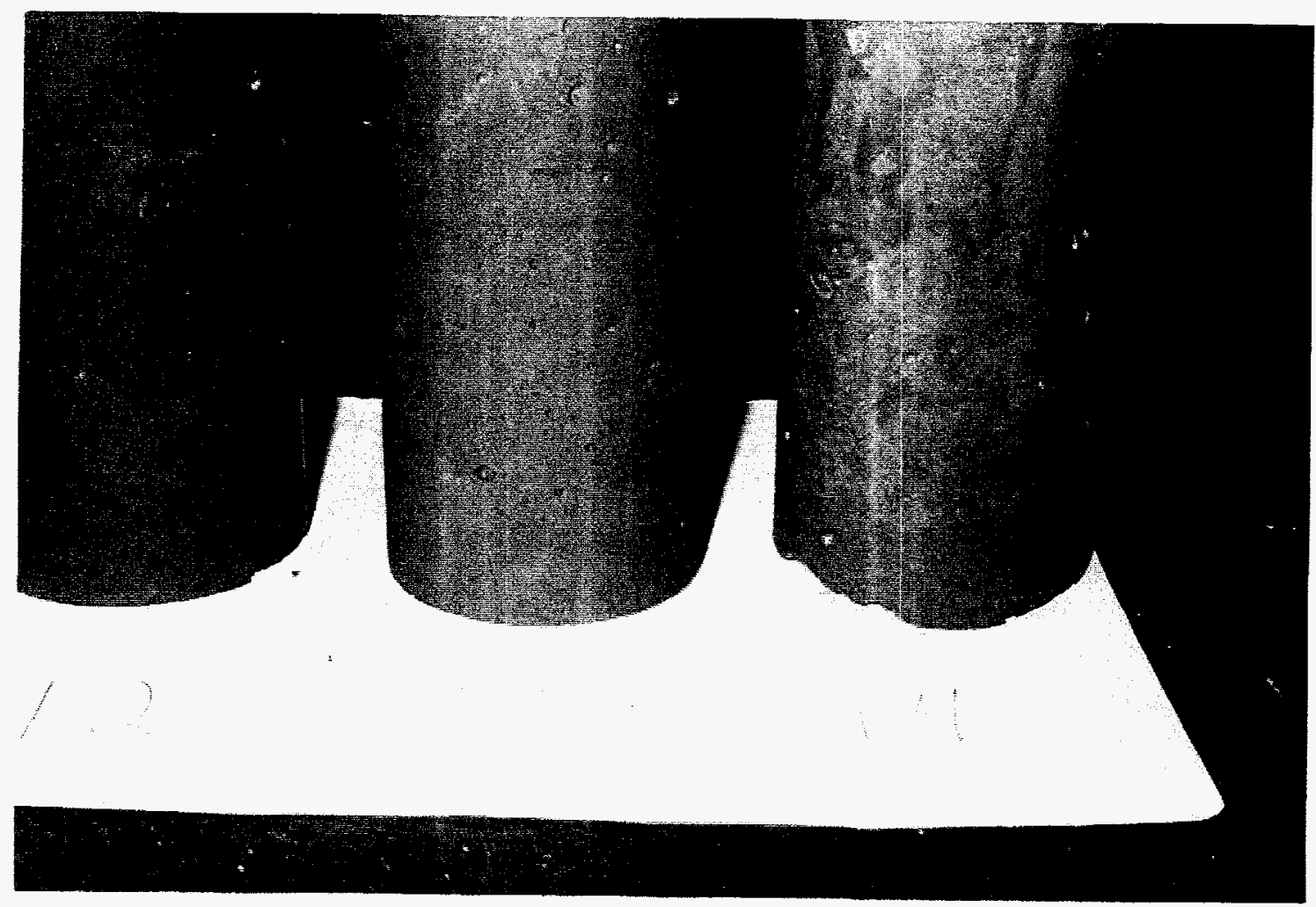

Figure 4-23. Photograph of Batches 12, 13, and 14 Soil Concrete

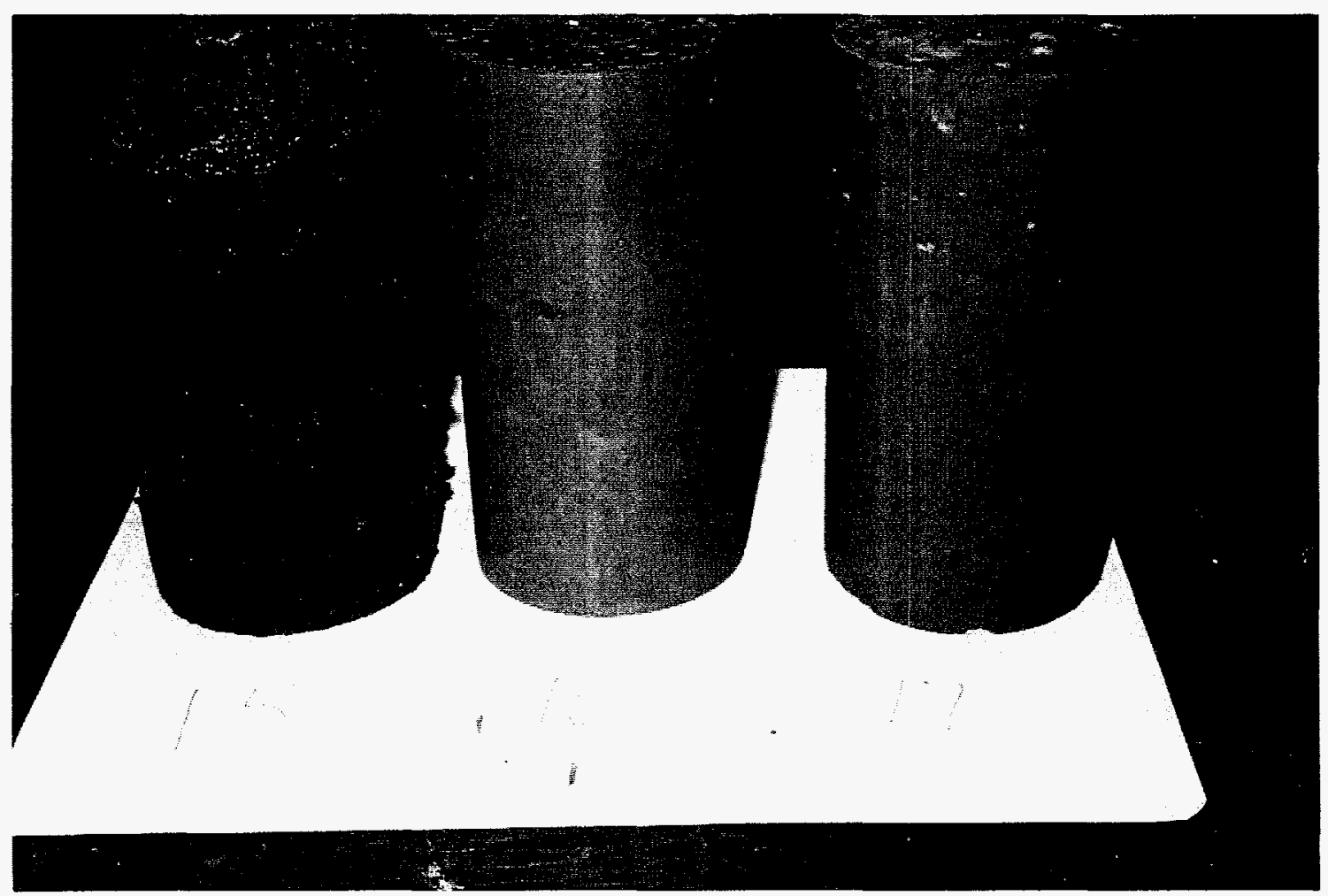

Figure 4-24. Photograph of Batches 15, 16, and 17 Soil Concrete 


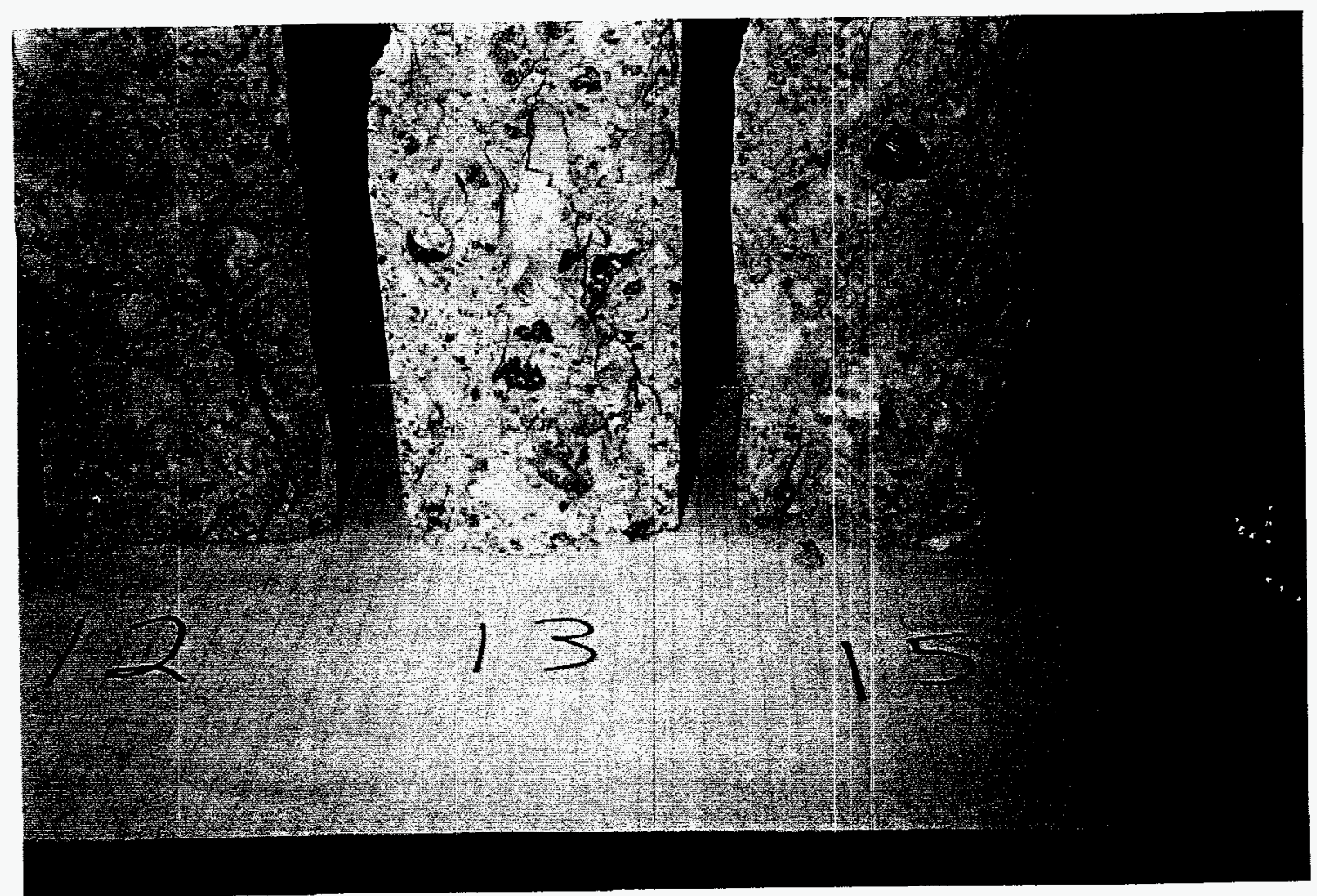

Figure 4-25. Photograph of Soil Concrete Samples Split in Half

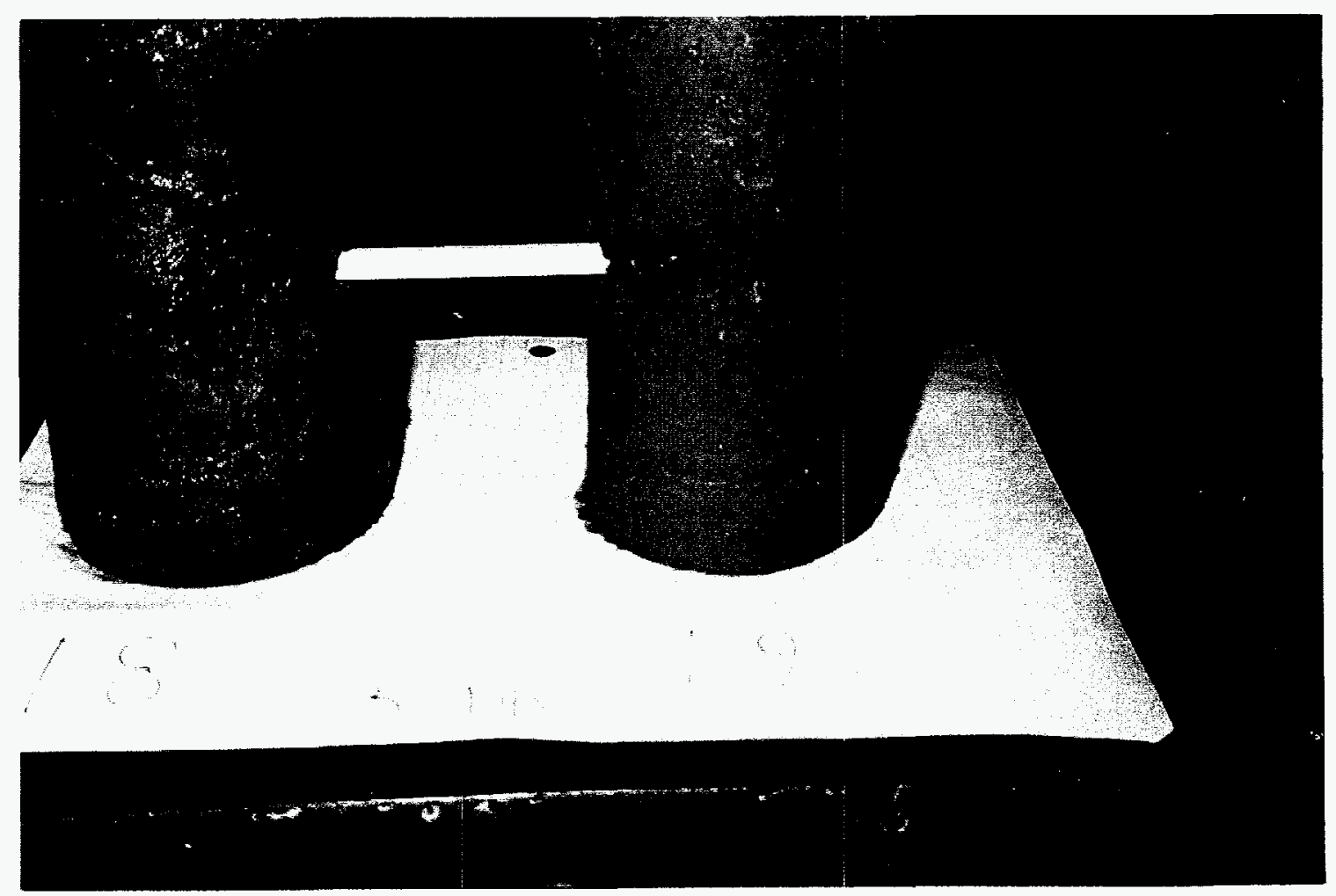

Figure 4-26. Photograph of Batches 18 and 19 Soil Concrete Cured for 3 Days. The pen inserted into the samples shows the lack of structural integrity. 


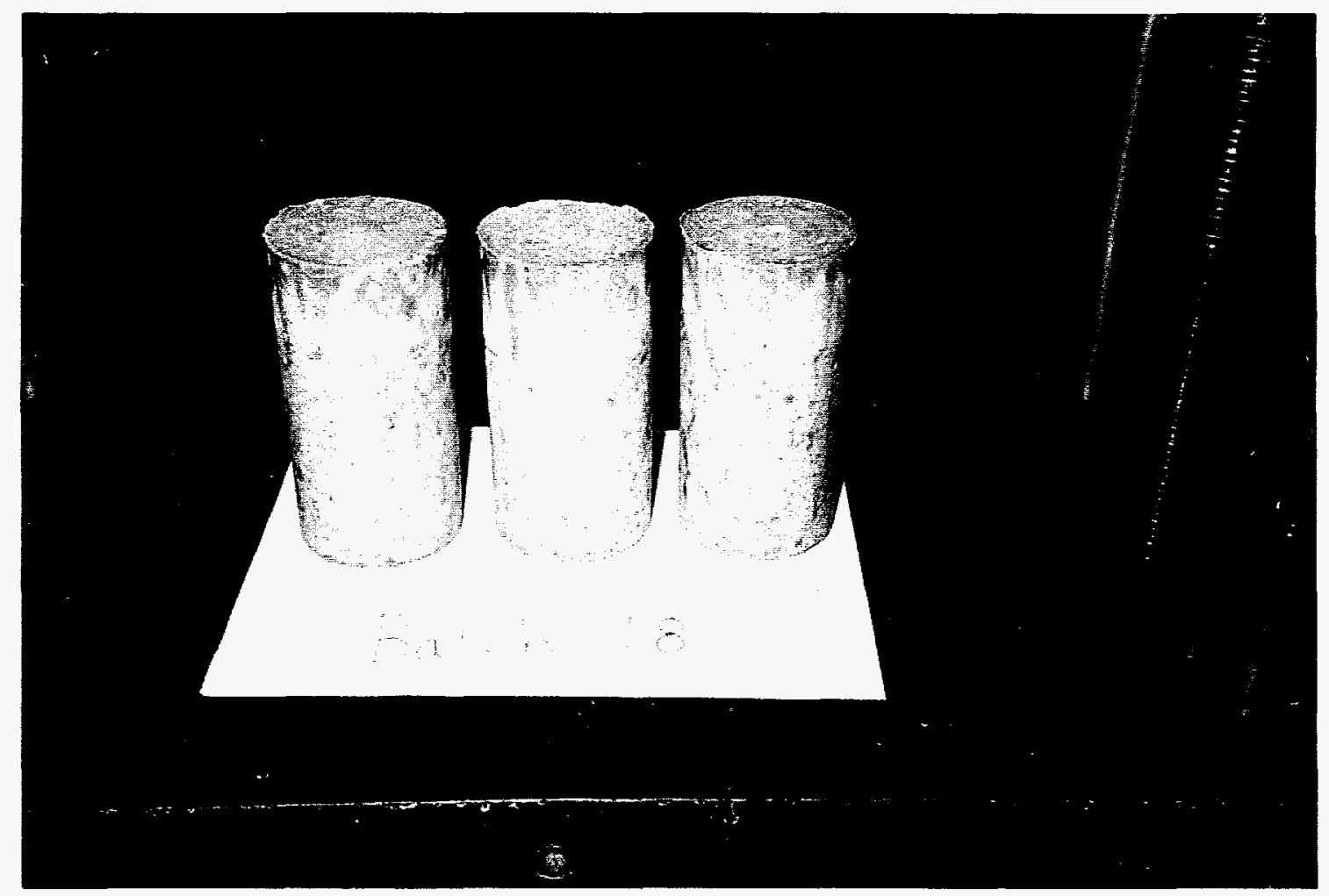

Figure 4-27. Photograph of Batch 18 Soil Concrete 


\section{Discussion}

This section discusses deviations from test methods and presents explanations in the most important areas of the research.

\subsection{Reduction Experiments}

Based on the results from reduction experiments, ferrous ammonium sulfate and ferrous sulfate were the best reducing agents. While preparing reduction experiment 12 samples, it was noted that the sample containing ferrous sulfate was reduced immediately. It was evident that the $\mathrm{Cr}$ (VI) was reduced because the fluid in the vial turned orange, indicating oxidation of $\mathrm{Fe}$ (II) to $\mathrm{Fe}$ (III); this oxidation coincided with the chromium reduction. Upon addition of ferrous ammonium sulfate, an orange trail was left behind as the ferrous ammonium sulfate fell to the bottom of the vial, indicating rapid oxidation of $\mathrm{Fe}(\mathrm{II})$ to $\mathrm{Fe}$ (III). Although numerous commercial chemical companies were contacted, ferrous ammonium sulfate is only available through laboratory suppliers. Thus, use of ferrous ammonium sulfate would not be economically feasible to stabilize the large amount of contaminated soil at SNL/NM. Ferrous sulfate, on the other hand, is commercially available from various sources around the country. After determining material availability, the decision was made to use ferrous sulfate as the reducing agent. Because of this decision, the remaining reduction experiments, 14 through 17, utilized ferrous sulfate as the reducing agent.

After the reactions had occurred in reduction experiment 12, a few samples were measured for $\mathrm{pH}$ (as indicated in Table 4-6). The $\mathrm{pH}$ changed from 7.9 and 8.9 to 3.9 in the ferrous sulfate samples and from 7.9 and 8.9 to 3.6 in the ferrous ammonium sulfate samples. This shift in $\mathrm{pH}$ is consistent with the reduction reactions presented in Section 2.3.

\subsection{Toxicity Characteristic Leaching Procedure Extract: Relationship of the Chromium Concentration to Ferrous Sulfate}

The batch experiments provided necessary data to determine the amount of reducing agent to use in the mortar mixer experiments. The molar ratio of 4.4 moles of ferrous sulfate to 1 mole of $\mathrm{Cr}(\mathrm{VI})$ was successful in reducing the chromium in the mortar mixer experiments. The resulting fluid in the mixing bowl experiments had a chromium concentration of approximately $0.1 \mathrm{mg} / 1$. This molar ratio was used in the first set of contaminated soil concrete batches (1 through 11). In batches 1 through 11, the TCLP extract concentrations were greater than $1.0 \mathrm{mg} / 1$; although the concentrations were below the regulatory level of $5.0 \mathrm{mg} / \mathrm{l}$, it was necessary to determine why these high results occurred. 
Additional ferrous sulfate was mixed into batches 13 through 16 based on TCLP results from batches 1 through 11 . The reason more reducing agent was added is that the total chromium needed to be treated, not just the Cr(VI). Experiment results showed this idea was successful, and all TCLP extracts from batches 13 through 16 and 18 through 20 are less than or equal to $0.4 \mathrm{mg} / \mathrm{l}$, with most of the TCLP extract concentrations of samples approximately equal to $0.1 \mathrm{mg} / \mathrm{l}$ (see Figures 4-15, 4-16, 4-17, 4-19, and 4-20).

One possible explanation for the higher-than-expected concentrations in batches 1 through 11 is that $\mathrm{Cr}(\mathrm{III})$ was being converted to $\mathrm{Cr}$ (VI) upon addition of the cement. The $\mathrm{pH}$ of the soil is 8.1 . When ferrous sulfate is added, the $\mathrm{pH}$ will drop to somewhere near neutral and the pe will also drop. After the cement is added, the $\mathrm{pH}$ will increase. In batch 18 , the $\mathrm{pH}$ increased to 11.5 . The effects of $\mathrm{pH}$ changes on chromium speciation can be described by referring to Figure 5-1. Position 1 is the soil-water mix. The pathway leading to position 2 is produced when ferrous sulfate is added; the $\mathrm{pH}$ is lowered and the pe of the system is reduced. The pathway from position 2 to position 3 is produced when cement is added. Position 3 is the final $\mathrm{pH}$ and pe of the soil concrete. Chromium speciation changes when crossing the $\mathrm{Cr}_{2} \mathrm{O}_{3}-\mathrm{CrO}_{4}{ }_{4}^{2-}$ line.

By adding additional ferrous sulfate to treat the total chromium in the soil, point 2 on Figure 5-1 is reduced further to point 2'. Adding cement brings the system to point 3', which is below the $\mathrm{Cr}_{2} \mathrm{O}_{3}-\mathrm{CrO}_{4}{ }_{4}^{2-}$ line. Therefore, the chromium would remain as $\mathrm{Cr}$ (III).

The amount of chromium treated in the soil was the average total chromium [Cr(VI) and $\mathrm{Cr}(\mathrm{III})$ ] concentration determined earlier in this study (see Section 4.3.2). The reduction experiments helped determine that it is only necessary to treat the average total chromium concentration and not the highest sampled concentration. The benefit of this approach is that by treating the average value, high and low sample values (that may not be indicative of the average chromium concentration) will be averaged out; this will aid in treating large quantities of contaminated soil. The number of samples that need to be collected to determine the quantity of ferrous sulfate required for chromium reduction is reduced. 


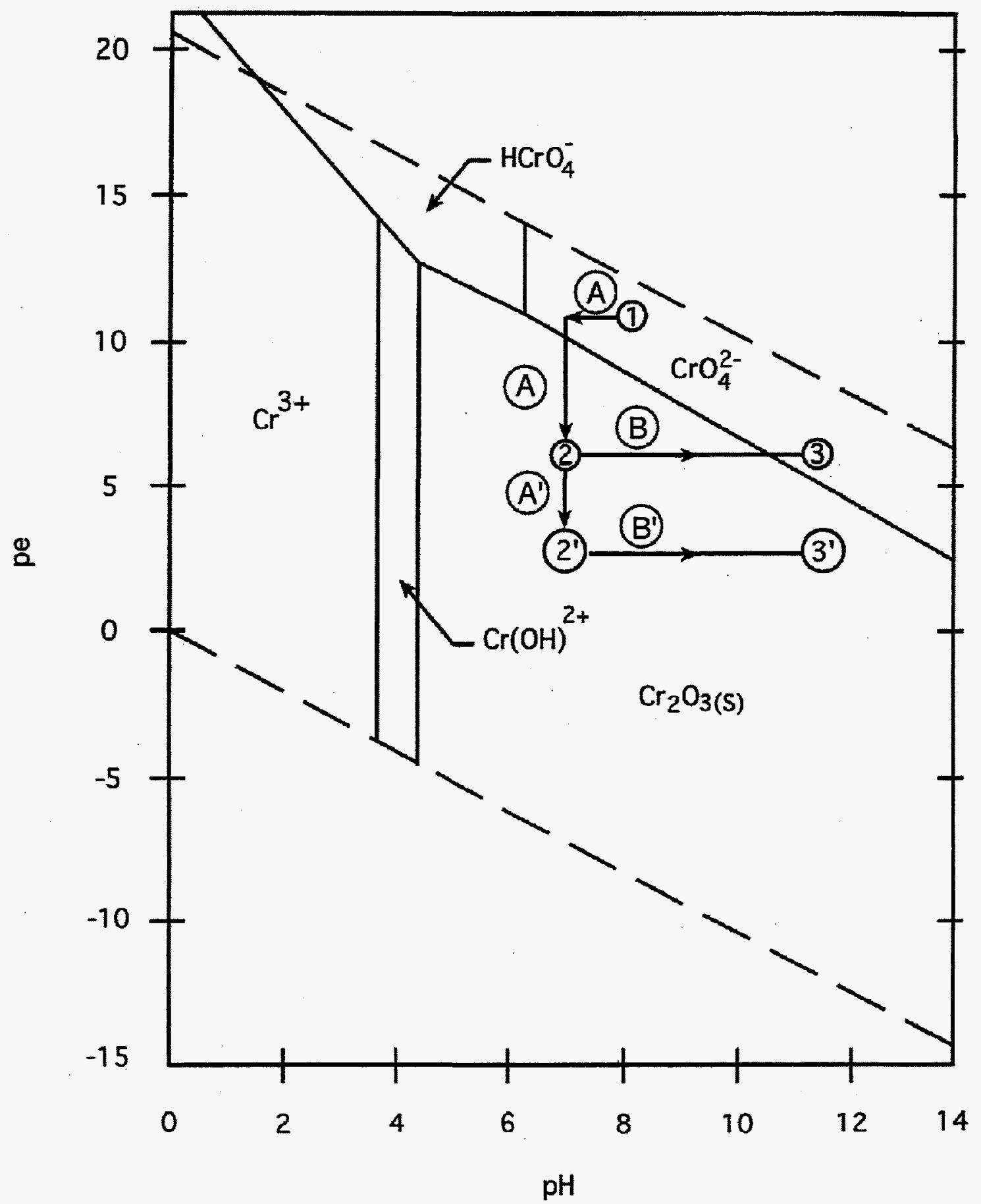

Figure 5-1. Schematic of effects of Stabilization/Solidification Process on Chromium Speciation; Total $[\mathrm{Cr}]=1 \times 10^{-5} \mathrm{M}$ (after Thomson 1987) Paths $A, A^{\prime}$ : ferrous sulfate addition Paths $B, B^{\prime}$ : addition of cement 


\subsection{Toxicity Characteristic Leaching Procedure Extract}

The chromium concentration in the TCLP extract was not equivalent in all samples from the same batch. This heterogeneity is best shown in Figures 4-19 and 4-20. In Figure 4-19, sample 18-5 had a chromium concentration of $0.4 \mathrm{mg} / 1$; whereas six other samples from the same batch had chromium concentrations of less than or equal to 0.1 $\mathrm{mg} / \mathrm{l}$. This heterogeneity is accounted for by individual samples containing soil with a higher $\mathrm{Cr}(\mathrm{VI})$ concentration than others. Treating the soil to obtain a chromium concentration in the TCLP extract of less than $0.5 \mathrm{mg} / 1$ provides a margin of safety if there is a "hot spot" of $\mathrm{Cr}(\mathrm{VI})$ in the soil.

As discussed in the preceding section, it is important to treat the total chromium concentration, not just $\mathrm{Cr}(\mathrm{VI})$ in the soil, in order to reduce the chromium concentration in the extract. $\mathrm{Cr}$ (III) solubility is very low. As shown in Figure 1-2, solubility of $\mathrm{Cr}$ (III) in the TCLP extract is $10^{-12} \mathrm{M}$ to $10^{-15} \mathrm{M}$. The $\mathrm{pH}$ data of the TCLP extracts are important: $\mathrm{Cr}(\mathrm{III})$ solubility is a minimum at $\mathrm{pH} 7.0$. Table $5-1$ shows the $\mathrm{pH}$ of the TCLP extracts per batch.

Table 5-1. Average $\mathrm{pH}$ Values of Toxicity Characteristic Leaching Procedure Extracts

\begin{tabular}{|c|c|}
\hline Batch Number & pH Value \\
\hline 12 & 10.5 \\
\hline 13 & 10.1 \\
\hline 14 & 10.2 \\
\hline 15 & 7.5 \\
\hline 16 & 7.6 \\
\hline 17 & 8.1 \\
\hline 18 & 7.6 \\
\hline 19 & 7.6 \\
\hline
\end{tabular}

The $\mathrm{pH}$ is higher for the 10 percent cement-to-soil ratio (w/w) (batches 12,13 , and 14) than for the 6 percent cement-to-soil ratio (w/w) (batches $15,16,17,18$, and 19). Also, the $\mathrm{pH}$ is affected by the amount of ferrous sulfate added. No ferrous sulfate was added to batches 12 and 17 . Batches 13 and 15 had more ferrous sulfate added than 
batches 14 and 16, and there is a $0.1 \mathrm{pH}$ difference in both sets. Batches 18 and 19 had the same amount of cement and ferrous sulfate as batch 15 .

Recent research has shown that $\mathrm{Cr}(\mathrm{VI})$ may be absorbed by concrete. Weng et al. (1996) studied the migration of $\mathrm{Cr}(\mathrm{VI})$ into concrete and absorption of $\mathrm{Cr}$ (VI) by concrete. In the $\mathrm{pH}$ range of TCLP extracts for batches 15 and $18(\mathrm{pH} 7.5)$, the soil concrete may absorb up to $0.1 \mathrm{mg} / 1$ (Weng et al. 1996). This is not a significant value in itself; however, it may aid in reducing the $\mathrm{Cr}(\mathrm{VI})$ concentration in the TCLP extract. [These data are for an initial concentration of $0.5 \mathrm{mg} / \mathrm{l}$ of $\mathrm{Cr}(\mathrm{VI}$.$) ]$

\subsection{Stability of Trivalent Chromium in the Environment}

The soil from the mortar mixer experiments was left covered, but not sealed, for the duration of this study. A grab sample, consisting of soil and water obtained by dipping a $600-\mathrm{ml}$ beaker into the 5-gal. bucket of soil-water mix, was analyzed colorimetrically 32 days after the mortar mixer experiments. The sample was filtered and analyzed in accordance with EPA Method 7196, and the chromium remained as $\mathrm{Cr}$ (III). This test was performed to show that after 32 days, the $\mathrm{Cr}$ (III) did not oxidize to $\mathrm{Cr}$ (VI). These results may indicate that the chromium will remain as $\mathrm{Cr}$ (III) in the treated waste form.

\subsection{Particle Size Analysis: Effect on Soil Chromium Concentration}

The particle size analysis produced noteworthy results. The sieve analysis procedure specified washing the soil through a No. 200 sieve to remove all the -200 material from the sample. This washing process was not performed because it would have removed some or all the $\mathrm{Cr}(\mathrm{VI})$ from the soil. Because this process was not performed, some -200 material with high chromium concentration may have remained adhered to the larger particles, possibly causing the chromium concentration to be higher than would be found in the +100 soil after sieving. This increased concentration may have affected the data shown in Figure 4-6. The +100 soil had a higher total chromium concentration than the composite soil, $1321 \mathrm{mg}$ of total chromium per kilogram of soil, and $1212 \mathrm{mg}$ of total chromium per kilogram of soil, respectively. The -100 soil had a total chromium concentration of $1961 \mathrm{mg}$ of total chromium per kilogram of soil. Logically, the composite soil would have a higher total chromium concentration than the +100 soil, because the composite soil contained the -100 soil which has the highest chromium concentration.

Another possible explanation for the +100 soil having a higher total chromium concentration than the composite soil is that all samples were grab samples. Although three samples were taken from each soil classification, it is possible that the +100 samples contained "packets" of soil containing high concentrations of chromium. 


\subsection{Importance of Studying the Waste}

The heterogeneous nature of the chromium contamination and the presence of foreign material in the soil stresses the importance of using soil from the site, rather than doping uncontaminated soil for the treatability study. The heterogeneous nature of the contamination produces "hotspots" in the soil. The treatment must be able to accommodate this situation to be effective. Foreign material, especially organics (e.g., roots) could lead to problems in the solidification process. Figure 5-2 shows a photograph of the soil. Notice the brown glass and the shred of plastic. The foreign material did not cause any problems in this study and the soil was successfully stabilized.

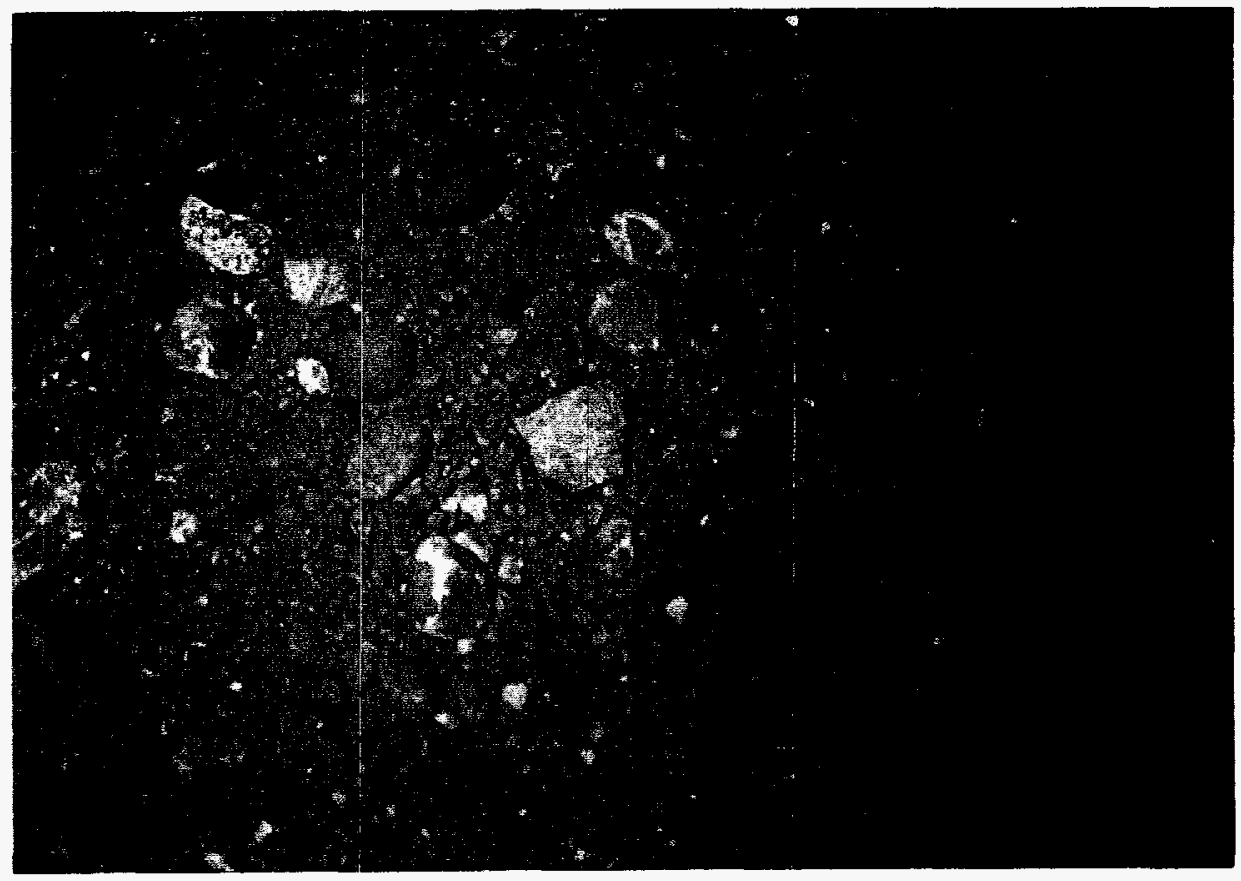

Figure 5-2. Photograph of the Soil 


\subsection{Water-to-Cement Ratio}

The strength of the soil concrete is dependent on the water-to-cement ratio (described in Section 2.4). Batches 1 through 7 were intended to be made with a waterto-cement ratio of $0.4(\mathrm{w} / \mathrm{w})$. The amount of water adsorbed by the soil and the amount necessary for cement hydration are two values that affect soil concrete strength. These two values could be calculated; however, the amount of water that the ferrous sulfate and the sodium silicate would adsorb was not considered. For this reason, the water-tocement ratio was less than the planned $0.4(\mathrm{w} / \mathrm{w})$. The soil concrete was too firm and had to be dug out of the mixing bowl; this consistency would not be amenable to a field-scale process. The soil concrete should be pourable while mixing; batches 8 through 11 were made with this in mind. Water was added until the mix was pourable, but not selfleveling. This required approximately a 35 percent increase in the total amount of water added. Figure $4-10$ shows the decrease in strength with higher water content. The batches made pourable are approximately $2 / 3$ as strong as their counterpart. The rough surface on the earlier batches is indicative of reduced water content (see Figure 4-22).

\subsection{Effect of High Sulfate Concentration}

The late setting of concrete caused by a high sulfate concentration was witnessed in this study (discussed in Section 2.1). Figure 4-14 presents data showing the impact of sulfate concentration on setting time of the soil concrete. Batches 13 and 15 had the most ferrous sulfate added. Batches 12 and 17 had no ferrous sulfate added. The addition of ferrous sulfate increased the sulfate concentration by $10,680 \mathrm{mg}$ of $\mathrm{SO}_{4}{ }^{2-}$ per kilogram of soil for batches 13,15 , and 18 through 20 and increased the sulfate concentration by $6,606 \mathrm{mg}$ of $\mathrm{SO}_{4}{ }^{2-}$ per kilogram of soil for batches 14 and 16 . This addition makes the total sulfate concentration approximately $20,000 \mathrm{mg}$ of $\mathrm{SO}_{4}{ }^{2-}$ per kilogram of soil for batches 13, 15, and 18 through 20. Evidence of the late set is also shown in Figure 4-18 for batches 18 and 19 .

The sulfate concentration in the TCLP extract, $720 \mathrm{mg} / 1$, exceeds the EPA recommended level of $250 \mathrm{mg} / 1$ (Driscoll 1986). However, the TCLP is an aggressive test and any leachate from the soil concrete would be mixed with groundwater and the sulfate concentration would be diluted. High sulfate levels are not dangerous. The health effect of sulfate upon people unaccustomed to drinking water with elevated levels is that these salts may act as a laxative (Driscoll 1986).

\subsection{Effect of Sodium Silicate Addition}

Sodium silicate was added to numerous batches to test its effect on reducing chromium leachability. Review of these data shows that the addition of sodium silicate in the amounts of 5 percent and 15 percent to cement $(w / w)$ had no significant effect on the chromium leachability. Sodium silicate could possibly have had a positive effect if a larger amount was added. The chromium concentration in the TCLP extract was at an 
acceptable level, so there was no reason to increase the amount of sodium silicate. The addition of sodium silicate is also an extra process step and expense.

\subsection{Verifying the Results of the Toxicity Characteristic Leaching Procedure}

The untreated soil TCLP results obtained by GEL agreed with the soil TCLP results obtained at UNM; however, the treated-soil TCLP results did not share the same agreement (see Tables 4-8 and 4-10). It is difficult to account for the disagreement. Both untreated and treated soil samples were investigated with the same laboratory precision and quality control at UNM. It may have been the heterogeneous nature of the soil that caused the discrepancy in results. The half of the sample sent to GEL may have contained "hot spots" of chromium. Even though GEL's results appear to be significantly higher, they are well within one order of magnitude of UNM's results and far below the regulatory limit of $5 \mathrm{mg} / \mathrm{l}$. Therefore, the reduction of $\mathrm{Cr}(\mathrm{VI})$ was a success.

\subsection{Additional Batch Experiment Information}

Sulfate and ammonia were added to batch experiments to adjust $\mathrm{pH}$. Adding these reagents and other chemicals present in the soil would complicate the reactions presented in Section 2.3. For simplicity, they were left out of the reactions. Therefore, the reactions presented in section 2.3 are only theoretical; however, they are useful to explain the redox environment.

An interesting result in the batch experiments was the floc produced upon addition of the reducing agent in reduction experiments 12 and 13. At pH 9.9 and below, the floc was an orange color with a specific gravity near 1 . Above a $\mathrm{pH}$ of 9.9 , the floc was a blue-green color and denser than the orange floc. The most probable reason for these differences in the flocs is that some chromium was being reduced to the +2 oxidation state. Additional electrons were being provided by the oxidation of ammonia to nitrogen. As the $\mathrm{pH}$ increases, the pe required for $\mathrm{NH}_{3}$ oxidation to $\mathrm{N}_{2}$ decreases. Figure 5-3 shows this relationship. The $\mathrm{pK} 1$ for the ammonia system is 9.3 . The green color is typical of eskolaite, with chromium in the +3 . A blue color is typical of chromium in the +2 oxidation state (Kroschwitz 1993). The ammonium ion was present in every sample with the blue-green floc, and was absent in samples without the blue-green floc.

\subsection{Field-Scale Operations}

One objective of this study was to formulate a stabilization and solidification process for chromium-contaminated soil that is applicable to field operations. This objective was accomplished by choosing commercially available reducing and solidification agents and by controlling the consistency of the wet soil concrete. 
The process of stabilization and solidification performed in this study can be scaled to field operations. First, the Cr(VI) must be put into solution by adding water to the soil and mixing for 1 to 2 minutes. Then, ferrous sulfate should be added and mixed for 1 to 2 minutes before adding the cement. Rocks larger than 1 inch were removed from this study to comply with ASTM C192-90a. This step (removal of rocks larger than $1 \mathrm{inch}$ ) would not be performed in the field, and aggregate as large as $1 / 3$ of the waste container diameter could be solidified and maintain strengths relative to those reported in this study.

Ferrous sulfate is available from Crown Technology in Indianapolis, Indiana for $\$ 125$ per ton. The material could be shipped from their California plant for approximately $\$ 700$ per truckload; a truckload is $22,000 \mathrm{lb}$. Type V Portland cement is available locally from Rio Grande Portland Cement Corporation for $\$ 70$ per ton. Quoted prices were based on purchasing material by the ton. Material costs to treat 1 ton of contaminated soil would be approximately $\$ 12$. This cost is for the composite soil and includes transportation. 


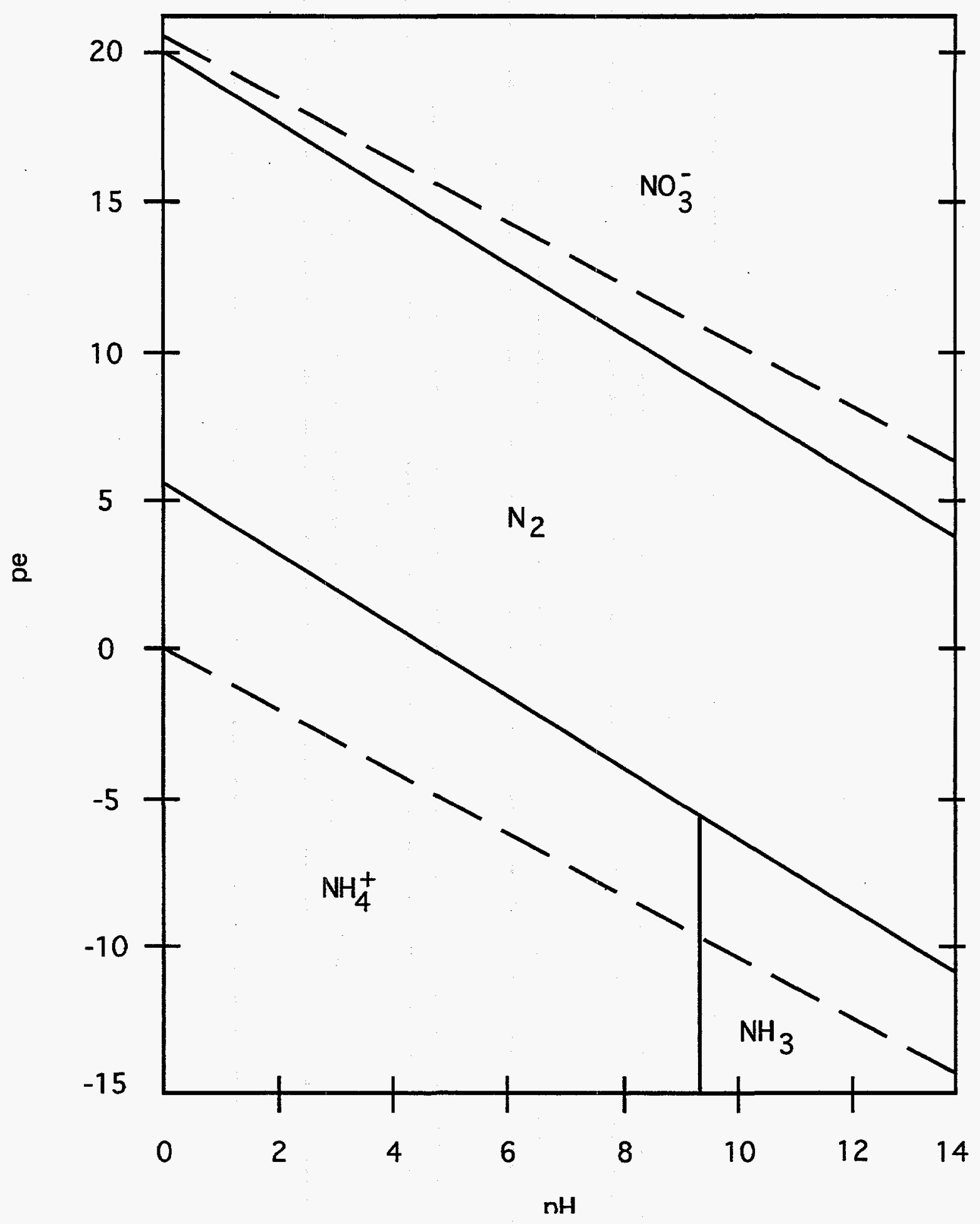

Figure 5-3. Diagram of pe-pH for Nitrogen; Total $[\mathrm{N}]=1 \times 10^{-3} \mathrm{M}$ (Pankow 1991) 


\section{Conclusions}

The chromium-contaminated soil was successfully stabilized and solidified by combining it with ferrous sulfate and Type V Portland cement using a process amenable to field-scale operations. Both of the added materials are commercially available and relatively inexpensive. The optimal mixture is 4.4 moles of ferrous sulfate per mole of total chromium with a 6 percent cement-to-soil ratio $(w / w)$, and the consistency of the soil concrete in the mixer should be pourable, but not self-leveling.

Zero-valent iron, blast furnace slag, and ferrous sulfide were not successful reducing agents. Ferrous sulfide reduced $\mathrm{Cr}(\mathrm{VI})$ at elevated $\mathrm{pH}$ values but the kinetics were too slow. Zero-valent iron could not reduce $\mathrm{Cr}(\mathrm{VI})$ at $\mathrm{pH}$ values above 2.0. Blast furnace slag did not reduce $\mathrm{Cr}(\mathrm{VI})$ at any $\mathrm{pH}$ value.

It is necessary to treat the total chromium concentration [ $\mathrm{Cr}(\mathrm{VI})$ and $\mathrm{Cr}(\mathrm{III})]$ in the soil to minimize the chromium in the TCLP extract. Only a limited number of soil samples for analysis for chromium need to be taken for successful treatment. The values for the soil sample concentration should be averaged to determine the amount of ferrous sulfate required for treatment. Using this method will reduce the chromium concentration in the treated TCLP extract to less than $0.5 \mathrm{mg} / 1$, providing up to 99 percent reduction in the TCLP extract concentration.

The cement-to-soil ratio was optimized to obtain a compressive strength in the range of 150 to $300 \mathrm{psi}$. The composite soil concrete had a 28-day average strength of $310 \mathrm{psi}$ with a cement-to-soil ratio of 6 percent $(\mathrm{w} / \mathrm{w})$. Although an average strength of 310 psi is slightly higher than the target range, this value adds a factor of safety for field operations. The addition of unnecessary water during field operations could easily reduce the strength by $50 \mathrm{psi}$. The -100 soil concrete had a 28 -day average strength of $156 \mathrm{psi}$ with a cement-to-soil ratio of 9 percent $(w / w)$.

Variation of sodium silicate content did not cause systematic changes in the strength of the soil concrete or the chromium concentration in the TCLP extract. The range of sodium silicate percentages was not fully tested because an acceptable TCLP extract concentration was achieved without the use of sodium silicate.

It is necessary to use the waste from the site rather than to dope similar soil in the attempt to obtain the same geochemical conditions. The waste solution has been in contact with the soil for approximately 20 years. In this amount of time, numerous in situ processes may have occurred, including redox reactions and chemical substitutions; it would be difficult to attain this condition artificially. results.

TCLP results from an outside laboratory provided verification of the UNM TCLP 


\section{References}

American Society for Testing and Materials (ASTM), 1995a. "Cement; Lime; Gypsum," Vol. 04.01, American Society for Testing and Materials, Philadelphia, PA.

American Society for Testing and Materials (ASTM), 1995b. "Soil and Rock(I): D420-D4914," Vol. 04.08, American Society for Testing and Materials, Philadelphia, PA.

American Society for Testing and Materials (ASTM), 1995c. "Concrete and Aggregates," Vol. 04.02, American Society for Testing and Materials, Philadelphia, PA.

Blowes, D. W., C. J. Ptacek, C. J. Hanton-Fong, and J. L. Jambor, 1995. "In Situ Remediation of Chromium Contaminated Groundwater Using Zero-Valent Iron," American Chemical Society Conference, Anaheim, CA, April 2-7, 1995.

Bowles, J. E., 1992. Engineering Properties of Soils and Their Measurement, 4th Edition, McGraw-Hill, Inc., New York, NY.

Conner, J. R., 1986. "Fixation and Solidification of Wastes," Chemical Engineering, November 10.

Conner, J. R., 1990. Chemical Fixation and Solidification of Hazardous Wastes, Van Nostrand Reinhold, New York, NY.

Driscoll, F. G., 1986. Groundwater and Wells, Johnson Filtration Systems Inc., St. Paul, MN.

U.S. Environmental Protection Agency (EPA), 1980a. “Ambient Water Quality Criteria for Chromium," EPA 440/5-80-035, U.S. Environmental Protection Agency, Washington, DC.

U.S. Environmental Protection Agency (EPA), 1980b. "Guide to the Disposal of Chemically Stabilized and Solidified Waste," SW-872, U.S. Environmental Protection Agency, Washington, DC.

U.S. Environmental Protection Agency (EPA), 1986. "Handbook for Stabilization/Solidification of Hazardous Wastes," EPA/540/2-86/001, U.S. Environmental Protection Agency, Washington, DC.

U.S. Environmental Protection Agency (EPA), 1996. "40CFR261.24 Toxicity Characteristic, U.S. Government Printing Office, Washington, DC.

Gillot, J. E., 1968. Clay in Engineering Geology, Elsevier Publishing Company, New York, NY. 
Glasser, F. P., 1992. "Progress in the Immobilization of Radioactive Wastes in Cement," Cement and Concrete Research, Vol. 22, pp. 201-216.

Jackman, A. P., and R. L. Powell, 1991. Hazardous Waste Treatment Technologies, Noyes Publications, Newark, NJ.

Jacobs, J. H., 1992. "Treatment and Stabilization of a Hexavalent Chromium Containing Waste Material," Environmental Progress, Vol. 11, No. 123-126, May.

Kindness, A., A. Macias, and F. P. Glasser, 1994. "Immobilization of Chromium in Cement Matrices," Waste Management, Vol. 14, No. 1, pp. 3-11.

Kroschwitz, J. I., executive editor, 1993. Kirk-Othmer Encyclopedia of Chemical Technology, Volume 6, John Wiley and Sons, New York, NY.

Lydon, F. D., 1972. Concrete Mix Design, Applied Science Publishers LTD, London, United Kingdom.

Orchard, D. F., 1979. Concrete Technology, Applied Science Publishers LTD, London, United Kingdom.

Pankow, J., 1991. Aquatic Chemistry Concepts, Lewis Publishers, Beaverton, OR.

Patterson, J. W., 1985. Industrial Wastewater Treatment Technology, Second Edition, Butterworth Publishers, Boston, MA.

Sandia National Laboratories, New Mexico (SNL/NM), 1992. "Chemical Waste Landfill Final Closure Plan and Post-Closure Permit Application," Environmental Restoration Project, Sandia National Laboratories, Albuquerque, NM.

Sandia National Laboratories, New Mexico (SNL/NM), 1993. "Chemical Waste Landfill Unsaturated Zone Contaminant Characterization," Sandia National Laboratories, Albuquerque, NM.

Stein, C. L., 1994. "Chromium Geochemistry in Calcareous Soils," Department of Geological Sciences, University of Washington AJ-20, Seattle, WA.

Thomson, B. M., 1987. "Microbially Induced Reduction and Precipitation of Aqueous Metal Contaminants," Presented at the 60th Annual Conference, Water Pollution Control Federation, Philadelphia, PA, October 6, 1987.

Trussell, S., and R. D. Spence, 1994. "A Review of Solidification/Stabilization Interferences," Waste Management, Vol. 14, No. 6, pp. 507-519.

Weng, C. H., C. P. Huang, H. E. Allen, P. B. Leavens, and P. F. Sanders, 1996. "Chemical Interactions between Cr (VI) and Hydrous Concrete Particles," Environ. Sci. Technol. 1996, Vol. 30, No. 10, pp. 371-376. 
Appendix A

Tests and Procedures

A-1 
Intentionally Left Blank 
Table A-1. Tests Described in the Methods Section (excluding section 3.1)

\begin{tabular}{|l|l|}
\hline \multicolumn{1}{|c|}{ Test $^{\text {a }}$} & \multicolumn{1}{|c|}{ Reference $^{\text {b }}$} \\
\hline TCLP & $\begin{array}{l}\text { Resource Conservation and Recovery Act, Part 261, } \\
\text { Appendix II, Method 1311, TCLP }\end{array}$ \\
\hline Cr(VI) Analysis & $\begin{array}{l}\text { EPA, SW-846, Method 7196A, Chromium, Hexavalent } \\
\text { (Colorimetric) }\end{array}$ \\
\hline Total Chromium Analysis & $\begin{array}{l}\text { EPA, SW-846, Method 7190, Chromium (Atomic Absorption } \\
\text { Direct Aspiration) }\end{array}$ \\
\hline Soil Digestion & $\begin{array}{l}\text { EPA, SW-846, Method 3050A, Acid Digestion of Sediments, } \\
\text { Sludges and Soils }\end{array}$ \\
\hline TCLP Extract Digestion & $\begin{array}{l}\text { EPA, SW-846, Method 3010A, Acid Digestion of Aqueous } \\
\text { Samples and Extracts for Total Metals for Analysis by FLAA } \\
\text { or ICP Spectroscopy }\end{array}$ \\
\hline Cr(VI) Concentration in Soil & Author \\
\hline pH & Author \\
\hline Sulfate Concentration & Author \\
\hline Batch Tests & Author \\
\hline Soil Moisture & $\begin{array}{l}\text { ASTM D2216-92, Standard Test Method for Laboratory } \\
\text { Determination of Water (Moisture) Content of Soil and Rock }\end{array}$ \\
\hline Sieve Analysis & Bowles (1992): Test 5 \\
\hline Soil Absorption & $\begin{array}{l}\text { ASTM C128-93, Standard Test Method for Specific Gravity } \\
\text { and Absorption of Fine Aggregate }\end{array}$ \\
\hline Bulk Density & Author \\
\hline Soil Concrete Preparation & $\begin{array}{l}\text { ASTM C192-90a, Standard Practice for Making and Curing } \\
\text { Concrete Specimens in the Laboratory }\end{array}$ \\
\hline Soil Concrete Strength Testing & $\begin{array}{l}\text { ASTM C39-93a, Standard Test Method for Compressive } \\
\text { Strength of Cylindrical Concrete Specimens }\end{array}$ \\
\hline
\end{tabular}

a TCLP $=$ Toxicity Characteristic Leaching Procedure

$\mathrm{Cr}(\mathrm{VI})=$ hexavalent chromium .

${ }^{b}$ RCRA = Resource Conservation and Recovery Act

EPA $=$ U.S. Environmental Protection Agency

FLAA = Flame Atomic Absorption Spectroscopy

ICP = inductively coupled plasma

ASTM $=$ American Society for Testing and Materials. 
Appendix B

Reduced Data 
Intentionally Left Blank

B-2 


\begin{tabular}{|c|c|c|c|c|c|}
\hline \multicolumn{6}{|c|}{ Chromium Concentration in Soil Samples } \\
\hline Sample & Total Cr (ppm) & $\mathrm{Cr}(\mathrm{VI})(\mathrm{ppm})$ & Sample & Total Cr (mg/kg) & $\mathrm{Cr}(\mathrm{VI}) \mathrm{mg} / \mathrm{kg}$ \\
\hline Plus 100 & 1369 & 279 & Plus 100 & 1321 & 273 \\
\hline Plus 100 & 1372 & 251 & Minus 100 & 1961 & 336 \\
\hline Plus 100 & 1222 & 289 & Composite & 1212 & 275 \\
\hline \multirow[t]{2}{*}{ Average } & 1321 & 273 & Chromiche (Y) & 1748 & 172 \\
\hline & & & Chromiche (R) & 126 & \\
\hline Minus 100 & 1813 & 345 & & & \\
\hline Minus 100 & 2004 & 329 & & & \\
\hline Minus 100 & 2065 & 335 & & & \\
\hline \multirow[t]{2}{*}{ Average } & 1961 & 336 & Sample & $\begin{array}{c}\text { Total } \mathrm{Cr} \\
\text { Concentration } \\
(\mathrm{mg} / \mathrm{kg})\end{array}$ & $\begin{array}{c}\operatorname{Cr}(\mathrm{Vl}) \\
\text { Concentration } \\
(\mathrm{mg} / \mathrm{kg})\end{array}$ \\
\hline & & & $26-28 \mathrm{ft}$ & 442 & 284 \\
\hline Composite & 1204 & 287 & $20-21 \mathrm{ft}$ & 1667 & 730 \\
\hline Composite & 1110 & 311 & $10-13 \mathrm{ft}$ & 5400 & 760 \\
\hline \multirow[t]{3}{*}{ Composite } & 1323 & 279 & & & \\
\hline & & 255 & & & \\
\hline & & 244 & & & \\
\hline Average & 1212 & 275 & & & \\
\hline
\end{tabular}




\begin{tabular}{|c|c|c|c|c|c|c|c|c|c|c|c|c|}
\hline \multicolumn{10}{|c|}{ Compressive Strength Values in Pounds per Square Inch } \\
\hline & Batch 1 & Batch 2 & Batch 3 & Batch 4 & Batch 5 & Batch 6 & Batch 7 & & Batch 8 & Batch 9 & Batch 10 \\
\hline 3-Day & 858 & 550 & 653 & 230 & 565 & 446 & 624 & 3-Day & 266 & 318 & 363 \\
\hline 7-Day & 944 & 840 & 891 & 342 & 856 & 583 & 757 & 7-Day & 437 & 442 & 546 \\
\hline 28-Day & 1245 & 1097 & 1448 & 641 & 1061 & 979 & 761 & 28-Day & 723 & 663 & 626 \\
\hline & & & & & & & & & & & \\
\hline & & & & & & & & & & & Batch 11 \\
\hline & & & & & & & & & & & 326 \\
\hline & & & & & & & & & & & 498 \\
\hline & & & & & & & & & & & 606 \\
\hline & & & & & & & & & & & \\
\hline & Batch 1 & Batch 8 & Batch 2 & Batch 9 & Batch 3 & Batch 11 & Batch 6 & & Batch 10 & & \\
\hline 3-Day & 858 & 266 & 550 & 318 & 653 & 326 & 446 & & 363 & & \\
\hline 7-Day & 944 & 437 & 840 & 442 & 891 & 498 & 583 & & 546 & & \\
\hline 28-Day & 1245 & 723 & 1097 & 663 & 1448 & 1245 & 979 & & 626 & & \\
\hline
\end{tabular}

\begin{tabular}{|l|r|r|r|r|r|r|}
\hline & Batch 12 & Batch 13 & Batch 14 & Batch 15 & Batch 16 & Batch 17 \\
\hline 3-Day & 256 & 15 & 121 & 0 & 12 & 45 \\
\hline 28-Day & 645 & 554 & 792 & 301 & 336 & 189 \\
\hline & & & & & & \\
\hline & & Batch 18 & Batch 19 & Batch 20 & & \\
\hline & 3-Day & 1 & 0 & & & \\
\hline & 7-Day & 12 & 18 & & & \\
\hline & 28-Day & 311 & 309 & 156 & & \\
\hline
\end{tabular}




\begin{tabular}{|c|c|c|c|c|c|c|c|c|c|c|c|}
\hline \multicolumn{12}{|c|}{ Chromium Concentration in TCLP Extracts (mg/l) } \\
\hline Batch & 1 & 2 & 3 & 4 & 5 & 6 & 7 & 8 & 9 & 10 & 11 \\
\hline 3-Day & 1.6 & 2.7 & 3.7 & 7.4 & 2 & 3 & 1.8 & 2 & 1.4 & 1.1 & 1.7 \\
\hline 3-Day Extra & & & & & & & & 1.9 & 1.2 & & \\
\hline 3-Day Extra & & & & & & & & & & & \\
\hline & & & & & & & & & & & \\
\hline 28-Day & 0.9 & 2.5 & 2.6 & 5.9 & 2.9 & 2.6 & 1.3 & 1.1 & 2.4 & 1 & 1.9 \\
\hline 28-Day Extra & & & & & & & & & & & \\
\hline & & & & & & & & 2 & 1.3 & 1.1 & 1.7 \\
\hline & 1 & 2 & 3 & 4 & 5 & 6 & 7 & 1.1 & 2.4 & 1 & 1.9 \\
\hline 3-Day & 1.6 & 2.7 & 3.7 & 7.4 & 2 & 3 & 1.8 & & & & \\
\hline 28-Day & 0.9 & 2.5 & 2.6 & 5.9 & 2.9 & 2.6 & 1.3 & & & & \\
\hline & & & & & & & & & & & \\
\hline & & & & & & & & & & & \\
\hline & 1 & 8 & 2 & 9 & 3 & 11 & 6 & 10 & & & \\
\hline 3-Day & 1.6 & 1.95 & 3.7 & 1.3 & 3.7 & 1.7 & 3 & 1.3 & & & \\
\hline 28-Day & 0.9 & 1.1 & 2.5 & 2.4 & 2.6 & 1.9 & 2.6 & 2.4 & & & \\
\hline & & & & & & & & & & & \\
\hline 12 & 13 & 14 & 15 & 16 & 17 & & & & & & \\
\hline 9.1 & 0.3 & 0.4 & 0.1 & 0.5 & 12.1 & & & & & & \\
\hline 11.6 & 0.9 & 1.3 & 0.2 & 0.5 & 11.9 & & & & & & \\
\hline & & & 1.1 & & & & & & & & \\
\hline & 12 & 13 & 14 & 15 & 16 & & & & & & \\
\hline 11.1 & 0.2 & 0.3 & 0.1 & 0.2 & 11.8 & & & & & & \\
\hline 10.2 & 0.3 & 0.4 & 0.1 & 0.2 & 12 & & & & & & \\
\hline
\end{tabular}




\begin{tabular}{|c|c|}
\hline \multicolumn{2}{|c|}{$\begin{array}{c}\text { Chromium Concentration in } \\
\text { TCLP Extracts (mg/l) }\end{array}$} \\
\hline Sample & Concentration (mg/l) \\
\hline $18-1$ & 0.1 \\
\hline $18-2$ & 0.1 \\
\hline $18-3$ & 0.2 \\
\hline $18-4$ & 0.1 \\
\hline $18-5$ & 0.4 \\
\hline $18-6$ & 0.2 \\
\hline $18-7$ & 0.05 \\
\hline $18-8$ & 0.05 \\
\hline $18-9$ & 0.05 \\
\hline $19-1$ & 0.1 \\
\hline $19-2$ & 0.3 \\
\hline $19-3$ & 0.2 \\
\hline $19-4$ & 0.1 \\
\hline $19-5$ & 0.1 \\
\hline $19-6$ & 0.2 \\
\hline $19-7$ & 0.05 \\
\hline $19-8$ & 0.1 \\
\hline $19-9$ & 0.05 \\
\hline $20-1$ & 0.1 \\
\hline $20-2$ & 0.1 \\
\hline & \\
\hline
\end{tabular}




\section{Distribution}

11148 Cindy Ardito (Intera), 6134

11148 Curtis Cherne, 6134

51148 Rarilee Conway, 6134

11148 Jim Studer (Intera), 6134

11148 Bruce Thompson (UNM), 6134

10161 Patent \& Licensing Office, 11500

19018 Central Technical Files, 8940-2

50899 Technical Library, 4916

20619 Review \& Approval Desk, 12690

For DOE/OSTI 